Winter 2016

\title{
To Loose the Bonds: The Deceptive Promise of Freedom from Pretrial Immigration Detention
}

Denise L. Gilman

university of texas law school, dgilman@law.utexas.edu

Follow this and additional works at: https://www.repository.law.indiana.edu/ilj

Part of the Civil Rights and Discrimination Commons, Constitutional Law Commons, Human Rights Law Commons, Immigration Law Commons, Law Enforcement and Corrections Commons, and the National Security Law Commons

\section{Recommended Citation}

Gilman, Denise L. (2016) "To Loose the Bonds: The Deceptive Promise of Freedom from Pretrial Immigration Detention," Indiana Law Journal: Vol. 92 : Iss. 1 , Article 4.

Available at: https://www.repository.law.indiana.edu/ilj/vol92/iss1/4

This Article is brought to you for free and open access by the Law School Journals at Digital Repository @ Maurer Law. It has been accepted for inclusion in Indiana Law Journal by an authorized editor of Digital Repository @ Maurer Law. For more information, please contact rvaughan@indiana.edu.

\section{$\Psi$}

JEROME HALL LAW LIBRARY

INDIANA UNIVERSITY

Maurer School of Law
Bloomington 


\title{
To Loose the Bonds: The Deceptive Promise of Freedom from Pretrial Immigration Detention
}

\author{
DENISE GILMAN*
}

Each year, the United States government detains more than 60,000 migrants who are eligible for release during immigration court proceedings that will determine their right to stay in the United States. Detention or release should be adjudicated through a custody determination process focused on the question of whether a migrant poses a flight risk or danger to the community. Yet, because the process skips the critical inquiry into the need for detention before setting monetary bond requirements for release that are difficult to fulfill, freedom remains elusive.

The custody determination process is a cornerstone in the U.S. immigration detention edifice but has received scarce attention. Furthermore, the public debate on mass incarceration, which could meaningfully inform the discussion, generally ignores the reality of expansive pretrial detention of migrants who could be released. This Article takes up the task of critiquing the role and functioning of the immigration custody determination process, in part by joining together the conversations taking place in the immigration and criminal pretrial realms.

In this Article, I assert that the immigration custody determination process fails to preserve and protect the constitutional presumption of liberty applicable to all persons facing detention that is not imposed as punishment after a criminal conviction. The process results in automatic detention without meaningful individualized consideration or review. Furthermore, it adopts elements from the criminal pretrial system that are ill suited to the immigration setting while failing to incorporate lessons learned in the criminal justice setting. Important considerations in the criminal justice context, such as the inadvisability of emphasizing monetary bond, do not make their way into the immigration custody determination process, with negative results for liberty.

Given these realities, the Article both proposes normative changes to the immigration custody determination process and calls for additional research in order to rationalize the process. These reforms would realign the system with the limited purposes of immigration detention in order to protect liberty and avoid the significant human and societal costs associated with detaining individuals who may safely be released.

INTRODUCTION 159

I. THE CUSTODY DETERMINATION PROCESS

A. INITIAL DHS CUSTODY DETERMINATIONS 165

B. CUSTODY REDETERMINATION BY DHS AND

THE IMMIGRATION COURT

* Clinical Professor and Director, Immigration Clinic, University of Texas School of Law; J.D., Columbia Law School; B.A., Northwestern University. I am grateful for comments received on drafts of this Article at a UT Law Drawing Board Luncheon and at The Borders of Crimmigration Conference in the Netherlands. Additional insights and suggestions offered by Ariel Dulitzky, Ingrid Eagly, Karen Engle, Mark Fleming, Barbara Hines, Elissa Steglich and Michael Tan greatly improved the Article. 
II. THE PRoblem WITH THE CUSTOdy Determination ProcesS ..........................171

A. LACK OF INDIVIDUALIZED DETERMINATION OF THE NEED TO DETAIN AS A

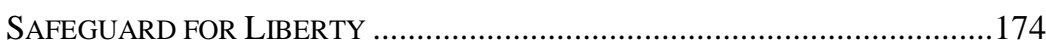

1. DEVELOPMENT OF DETENTION AS A DEFAULT …………...................175

2. NON-INDIVIDUALIZED PRESUMPTIVE DETENTION IN INITIAL DHS CUSTODY DETERMINATIONS ...........................................................178

3. LACK OF REVIEW OF NECESSITY OF DETENTION IN IMMIGRATION COURT CUSTODY REDETERMINATION HEARINGS ...........................187

4. THE OVERALL INADEQUACY OF THE CUSTODY DETERMINATION PROCESS AS CONTROL ON DETENTION............................................190

B. SELECTIVE BORROWING FROM THE CRIMINAL JUSTICE SYSTEM WITH

NEGATIVE CONSEQUENCES FOR LIBERTY ..............................................195

1. EMPHASIS ON MONETARY BONDS ...................................................195

2. THE PROBlematic USE OF CRIMINAL Justice PRETRIAL

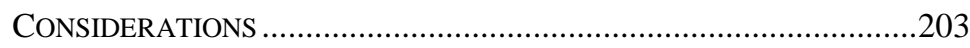

3. THE OVERALL IMPACT OF SELECTIVE BORROWING FROM THE CRIMINAL JUSTICE SYSTEM ON THE POTENTIAL FOR LIBERTY ........213

III. IMPLICATIONS OF THE FAILED CUSTODY DETERMINATION PROCESS ................213

IV. A NORMATIVE RESPONSE AND A CALL FOR ADDITIONAL RESEARCH...............217

A. REESTABLISHING PRESUMPTIVE LIBERTY AND INDIVIDUALIZED

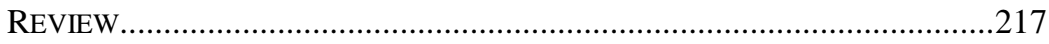

B. DETERMINING RISK FACTORS AND DESIGNING MEASURES TO ADDRESS

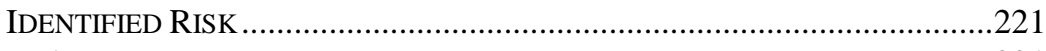

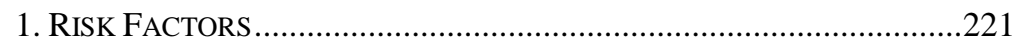

2. RELEASE AND RISK MANAGEMENT …………….........................223

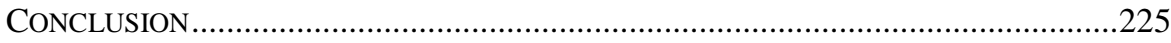


[C]ourts somehow give the impression that our system of bail preserves one of the most valuable rights of freedom. ... Through most of the United States today the bail system is a cruel and illogical institution which perpetuates injustice in the name of the law.

Attorney General Robert F. Kennedy ${ }^{1}$

[The United States must ensure] that the bond system does not become another obstacle that undocumented immigrants have to surmount in order to obtain the liberty to which they are, as a general rule, entitled.

Inter-American Commission on Human Rights ${ }^{2}$

\section{INTRODUCTION}

Each year, the United States detains more than 400,000 migrants in connection with immigration proceedings. ${ }^{3}$ The Department of Homeland Security (DHS) holds these migrants in a civil detention regime, which means that they are held for nonpunitive administrative purposes rather than for punishment pursuant to a criminal conviction. ${ }^{4} \mathrm{~A}$ significant number of these migrants in detention are awaiting the conclusion of drawn-out deportation proceedings in the immigration courts, which will determine whether they will remain lawfully in the United States or will be deported. ${ }^{5}$ In other words, these are pretrial detainees in the immigration detention system.

1. Robert F. Kennedy, Att'y Gen., U.S. Dep't of Justice, Address to the Academy of Trial Lawyers of Allegheny County 1 (June 1, 1964).

2. Inter-Am. Comm'n on Human Rights, Org. of Am. States, Report on IMMigRATION IN THE United STATES: Detention AND Due Process 82 [hereinafter IACHR REPORT ON DETENTION] (2010).

3. John F. Simanski, Office of Immigration Statistics, U.S. Dep't of Homeland SeC., Annual Report: ImMigration Enforcement Actions: 20131 (2014) (reporting 441,000 detained); U.S. ImmigRation AND Customs EnF't, U.S. DeP'T OF Homeland SeC., Draft Fiscal Year 2014 ICE ENFORCEMENT AND REMOVAl Operations RePort 8 (2014) (draft report on file with the Indiana Law Journal) (reporting 425,728 detained in 2014, the last year that DHS provided detention statistics). These figures do not include and this Article does not address unaccompanied migrant children who undergo a different process where release is prioritized and detention takes place in licensed shelters. 6 U.S.C § 279(a)-(b) (2012); Stipulated Settlement Agreement at 7-12, Flores v. Reno, No. CV 85-4544-RJK (Px) (C.D. Cal. Jan. 17, 1997).

4. Who We Are: Overview, U.S. IMmigRATION AND CUSTOMS ENF'T, http://www.ice.gov /about/overview [https://perma.cc/ST5E-P8FJ]; see also Immigration Enforcement: Detention Management, U.S. IMMIGRATION AND CUSTOMS ENF'T, http://www.ice.gov/detention-management [https://perma.cc/L4MS-27WA].

5. See 8 U.S.C. $§ 1226$ (a) (2012) (authorizing detention or release of migrants, "pending a decision on whether the alien is to be removed from the United States"); OfFICE OF Planning, Analysis, and Statistics, Exec. OfFice for Immigration Review, U.S. Dep'T of Justice, FY 2015: Statistics Yearbook C2-C4, K1, N1 (2016) [hereinafter EOIR STATISTICS YEARBOOK 2015] (providing information regarding favorable decisions in deportation proceedings allowing migrants to remain in this country). The proceedings are called "removal" proceedings but are commonly referred to as deportation proceedings, which is the terminology that I will use. 
By conservative estimate, out of the more than 400,000 migrants detained annually, at least 60,000 are held in pretrial detention despite eligibility for release. ${ }^{6}$ These migrants spend time in detention, and not infrequently remain detained throughout the entirety of the lengthy court proceedings, largely due to a flawed system of custody determination. ${ }^{7}$ Thus, for substantial numbers of migrants who could be released through the custody determination process, often called bond proceedings in

6. This estimate is derived from limited data available about those who seek review of pretrial detention in the immigration courts and is almost certainly underinclusive. Approximately 60,000 individuals sought custody redetermination hearings in immigration courts each year in 2014 and 2015. See EOIR STATISTICS YEARBOOK 2015, supra note 5, at A1, A7A8 (explaining that "bond redetermination hearings" are custody redetermination hearings and setting out that over 60,000 bond redetermination requests were made in 2014 and 2015). These 60,000 hearings serve as a proxy for determining how many individuals are releaseeligible but are detained pretrial for some period, because these hearings are only available to individuals who are held in custody in connection with deportation proceedings prior to a final order of deportation and who are not subject to mandatory detention. 8 C.F.R. $\S 1236.1$ (d) (2016). However, the hearings data serves as an imperfect proxy that errs toward undercounting. A small percentage of those who pursue custody redetermination hearings in immigration court are actually not eligible for those hearings and instead are subject to mandatory detention and so not eligible for release. See Julie Dona, Making Sense of "Substantially Unlikely": An Empirical Analysis of the Joseph Standard in Mandatory Detention Custody Hearings, 26 GeO. IMMigR. L.J. 65, 70-71 (2011) (finding fewer than 200 cases on Westlaw that involved hearings in mandatory detention cases that were appealed to the Board of Immigration Appeals over a four-year period). A much larger number of individuals will have been detained but then released by DHS, often upon payment of bond, before a custody redetermination hearing in immigration court could be held. See Ingrid V. Eagly \& Steven Shafer, A National Study of Access to Counsel in Immigration Court, 164 U. PA. L. REV. 1, 69-71 (2015) (noting that only $37 \%$ of migrants released from detention during immigration court deportation proceedings between 2007 and 2012 were released pursuant to an immigration court custody redetermination hearing); infra Part I.A. These individuals released by DHS will not have an immigration court custody redetermination hearing and so will not be included in the immigration court's figures but were in pretrial immigration detention for some period. In addition, some migrants who are not subject to mandatory detention pending immigration court deportation proceedings are nonetheless not eligible for an immigration court custody redetermination hearing and will also not appear in the immigration court figures. See infra Part I.B. The 60,000 estimate for release-eligible detainees pending immigration court deportation proceedings also is lower than but corresponds reasonably well with the number of such detainees calculated several years ago with more data available. See Denise Gilman, Realizing Liberty: The Use of International Human Rights Law To Realign Immigration Detention in the United States, 36 FordHAM INT'L L.J. 243, 327 (2013) (estimating 75,000 release-eligible individuals detained pretrial); see also HUMAN RiGHTS First, LifELINE ON LOCKDOWN: INCREASED U.S. DETENTION OF ASYLUM SEEKERS 11-12 (2016) (in fiscal year 2014, 44,270 asylum seekers alone were held in immigration detention; this figure does not include individuals in pretrial detention during pending deportation proceedings who are not seeking asylum). It is notoriously difficult to obtain from DHS the data necessary to calculate the exact number of detainees in any category. See, e.g., AMNESTY INT'L, JAILED Without JuSTICE: IMMigRATION DETENTION IN THE USA 6-7 (2009).

7. See N.Y. Immigrant RePRESEntation Study SteEring Comm., ACCESSing Justice II: A Model for Providing Counsel to New York Immigrants in Removal Proceedings 13 (2011), http://www.cardozolawreview.com/content/denovo/NYIRS_Report.pdf [https:// 
immigration parlance, the promise of freedom remains elusive. This Article will explore that reality.

The custody determination process is a cornerstone in the U.S. immigration detention edifice. ${ }^{8}$ Yet, the role of the custody determination system in the contemporary detention regime has received scarce attention. ${ }^{9}$ Scholars and advocates have occasionally criticized the rapid expansion of immigration detention generally ${ }^{10}$ and have intensely scrutinized mandatory detention, which makes certain categories of individuals ineligible for pretrial release, usually based on criminal history ${ }^{11}$ In contrast, they have neglected the growth of pretrial detention for releaseeligible individuals. Until very recently, the limited research on the custody determination process for release-eligible immigrants dated to more than twenty

perma.cc/GM64-5XB2] [hereinafter NYIRS REPORT] (91\% of those initially detained in New York remained detained); Eagly \& Shafer, supra note 6, at 65 (finding an average length of detention of 314 days for individuals who remain detained and obtain counsel to assist in seeking relief from deportation); Migration and Refugee Services/U.S. Conference of Catholic Bishops \& Center for Migration Studies, Unlocking Human Dignity: A Plan To Transform the US Immigrant Detention System, 3 J. ON Migration \& HuM. SECURITY 159, 178 (2015) (noting that "long-term detention persists for large numbers of persons with pending removal proceedings") [hereinafter Unlocking Human Dignity]; Decisions on ICE Detainees: State-byState Details, TRAC IMMIGRATION (May 22, 2013), http://trac.syr.edu/immigration/reports 1320/ [https://perma.cc/HR4R-BQUD] (demonstrating that the majority of immigration detainees remain in custody throughout immigration court deportation proceedings; finding that, in 2012 , only $25 \%$ of immigration detainees were released prior to a final immigration court decision in deportation proceedings and the remainder were released through deportation in execution of a final immigration court order or through a final favorable immigration court decision granting the right to remain in the United States).

8. See, e.g., EXec. OfFice of IMmigration REVIEW, IMMigration Judge BenCHBOOK: Bond GuIDE, https://www.justice.gov/sites/default/files/eoir/legacy/2014/08/15/Bond_Guide.pdf [https://perma.cc/2M2E-3E9J] (guide for immigration judges regarding the custody redetermination process) [hereinafter IJ BOND BENCHBOOK]; Janet A. Gilboy, Administrative Review in a System of Conflicting Values, 13 LAW \& Soc. INQUiRy 515, 520 (1988) (bond determinations are "an important feature of immigration law enforcement").

9. But see Alina Das, Immigration Detention: Information Gaps and Institutional Barriers to Reform, 80 U. CHI. L. REV. 137 (2013) (describing problems with the custody determination process as well as mandatory detention); Gilman, supra note 6, at 326-33 (using human rights to offer an initial analysis of detention for release-eligible migrants).

10. See, e.g., David Cole, In Aid of Removal: Due Process Limits on Immigration Detention, 51 EMORY L.J. 1003, 1006 (2002); Anil Kalhan, Rethinking Immigration Detention, 110 Colum. L. ReV. Sidebar 42 (2010).

11. See 8 U.S.C. § 1226(c) (2012) (mandatory detention statute); Lora v. Shanahan, 804 F.3d 601 (2d Cir. 2015) (challenge to prolonged mandatory detention without bond hearing); Rodriguez v. Robbins (Rodriguez II), 715 F.3d 1127, 1137 (9th Cir. 2013) (same); Diop v. ICE/Homeland Sec., 656 F.3d 221, 232-33 (3d Cir. 2011) (same); Gordon v. Johnson, 991 F. Supp. 2d 258 (D. Mass. 2013) (litigation urging limits on the category of persons subject to mandatory detention); Farrin R. Anello, Due Process and Temporal Limits on Mandatory Immigration Detention, 65 Hastings L.J. 363 (2014); Geoffrey Heeren, Pulling Teeth: The State of Mandatory Immigration Detention, 45 HARV. C.R.-C.L. L. REV. 601 (2010); Stephen H. Legomsky, The Detention of Aliens: Theories, Rules, and Discretion, 30 U. MiAmI INTER-AM. L. REV. 531 (1999). 
years ago when the immigration detention system was vastly smaller. ${ }^{12}$ A few important empirical research projects have recently assessed determinants of certain subsets of pretrial immigration detention decisions. ${ }^{13}$ However, the role and functioning of the custody determination process within the modern immigration detention system simply has not been studied.

In this Article, I critically analyze the process of custody determination and call for additional research for a number of reasons. First, advocates, policymakers, and scholars must better understand the process, which determines the detention fate of an entire segment of the immigrant population taken into DHS custody. Otherwise, it is impossible to grasp the full picture of the immigration detention system and its impact.

Second, critiques of the role of pretrial detention in mass incarceration in the criminal justice setting need to attend to the large numbers of migrants who are held pending immigration court deportation proceedings. Reforms that seek to limit pretrial criminal detention, to restore its exceptional and nonpunitive role,$^{14}$ could both inform and take caution from what is happening in the immigration context. To fully account for the impacts of pretrial detention on incarceration in the United States, the immigration system must receive attention. In fact, the number of release-eligible individuals in pretrial immigration detention is very similar to the number of pretrial detainees in the federal criminal justice system. ${ }^{15}$

12. See, e.g., U.S. COMM'N ON CIVIL Rights, ED198197, THE TARNISHED GOLDEN DoOR: Civil Rights Issues IN IMMigration 104-07 (1980) (citing INS, A COMPARISON OF THE BOND-SETTING PRACTICES OF THE IMMIGRATION AND NATURALIZATION SERVICE WITH THAT OF THE CRIMINAL COURTS 20-31 (1978) (reporting results of that study); EDWIN HARWOOD, IN LIBERTY's SHADOW: ILLEGAL ALIENS AND IMMIGRATION LAW ENFORCEMENT 120-21 (1986) Gilboy, supra note 8, at 520 \& n.32 (empirical study of bond decisions in Chicago in the early 1980s which cites a few earlier studies); Robert M. Sanders, Immigration Bond: An Analysis of the Determinants of Official Decisions, 20 CRIME, L. \& Soc. CHANGE 139 (1993).

13. Mark Noferi \& Robert Koulish, The Immigration Detention Risk Assessment, 29 GeO. IMMIGR. L.J. 45 (2014) (studying the risk classification tool aspect of initial custody determinations made at the DHS level); Emily Ryo, Detained: A Study of Immigration Bond Hearings, 50 L. \& SoC'Y REV. 117 (2016) (studying custody determinations made at the immigration court level in a specific subset of cases that were initially treated as falling within the mandatory detention scheme).

14. See, e.g., Timothy R. Schnacke, Nat'l Inst. Of Corr., Dep't. of Justice, Fundamentals of Bail: A Resource Guide for Pretrial Practitioners and A FramewORK FOR AMERICAN PRETRIAL REFORM iii-iv, 1-3, 35, 99-116 (2014) (setting out case law and standards establishing that criminal pretrial detention must be the exception and liberty the norm, given the civil nonpunitive nature of detention absent a conviction, and urging reform of pretrial systems to provide for presumptive pretrial release); Nick Pinto, The Bail Trap, N.Y. TIMES (Aug. 13, 2015), http://www.nytimes.com/2015/08/16/magazine/the -bail-trap.html [https://perma.cc/D2ZK-67XE] (highlighting extensive criminal pretrial detention as part of the mass incarceration problem and describing efforts at reform of the pretrial detention system); see also United States v. Salerno, 481 U.S. 739, 747 (1987) (clarifying that pretrial criminal detention must be limited and nonpunitive).

15. See Mark Motivans, Bureau of Justice Statistics, Dep't. of Justice, Federal Justice Statistics, 2012-Statistical Tables 13 (2015) [hereinafter Motivans, 2012 STATISTICAL TABLES] (approximately 70,000 defendants detained pretrial after initial hearing or detention hearing in 2012); Mark Motivans, Bureau of Justice Statistics, DeP'T. OF 
In addition, the study of the immigration custody determination process reveals that pretrial immigration detention is intertwined with pretrial detention in the criminal justice system. By analyzing the immigration custody determination process and its relationship to pretrial detention in the criminal justice context, an important connection is made between the conversations taking place in the immigration and criminal pretrial realms. This connection allows for a better assessment of the potential for erosion of the limits on nonpunitive detention in the immigration setting and more generally.

Unfortunately, a focused analysis on the immigration custody determination process provides much cause for concern. Bringing to bear the literature on immigration detention on one hand and nonimmigration criminal detention on the other, I contend that, as currently designed and implemented, the custody determination process fails to protect the constitutional right to liberty of immigrants. The process leads to automatic detention without meaningful individualized consideration or review. Furthermore, the process adopts elements from the criminal pretrial system that are ill suited to the immigration setting, even while failing to incorporate lessons learned in the criminal justice context. My argument proceeds as follows.

I will first provide a description of the custody determination process for release-eligible migrants in Part I of this Article. I will then proceed to describe a number of serious problems with the current system in Part II. Part II first establishes that the legal contours of the immigration custody determination process, along with implementation practices, make the process an ineffectual mechanism for ensuring that civil immigration detention adheres to its limited and nonpunitive purposes. Instead, the custody determination process imposes automatic detention as a starting point, without individualized determinations of necessity and without a guarantee of prompt release where detention is not justified by a specific flight risk or danger. Part II then turns to the impediments on obtaining release after a detention decision is made, which stem from the immigration system's adoption of elements from the criminal pretrial system while ignoring lessons learned in the criminal justice setting. An undue emphasis on monetary bond as a condition for release is identified as a central issue. Unjustified reliance on ill-fitting pretrial risk factors from the criminal justice system also leads to flawed custody decisions for migrants and the likelihood of ongoing detention.

Given the seriousness of these issues and the need to realign the system with the permissible purposes of immigration detention, in Part III, I offer some initial proposals for reconfiguring the custody determination process. The proposals would provide greater protections for the liberty interests of migrants while also avoiding significant costs to the system and society caused by detaining individuals who may safely be released. I will also suggest additional study to ensure that the system ensures that custody decisions are based on appropriate considerations and are closely tied to the legitimate goals of addressing flight risk or danger to the community.

Justice, Federal Justice Statistics, 2011-2012 at 2 (2015) [hereinafter Motivans, 20112012 FEDERAL JUSTICE STATISTICS] (61,255 pretrial detainees in federal confinement in 2012). 


\section{THE CUSTODY DETERMINATION PROCESS}

The process that determines custody for release-eligible migrants in immigration court deportation proceedings is opaque and has not been set out comprehensively in the literature. ${ }^{16}$ While multiple exceptions and details complicate matters considerably, at the most basic level, the process generally consists of two parts: (1) a DHS decision to detain or release made after apprehension, and (2) a subsequent immigration court custody redetermination hearing that takes place alongside the immigration court deportation proceedings. Importantly, pretrial custody determinations and deportation proceedings are connected but separate processes. Immigration court deportation proceedings do not require detention. A migrant may never be apprehended and detained at all but still be placed in immigration court deportation proceedings or may be detained but then released as the proceedings move forward. Conversely, pretrial detention for deportation proceedings does not mean that a migrant will necessarily be deported in the end. Some migrants may be detained pretrial during part or all of the immigration court deportation proceedings and then win the right to remain in the United States at the conclusion, achieving release as a result of that final decision. A more developed description of the custody determination process follows in order to unriddle the system's functioning and provide necessary background for the subsequent analysis. A flowchart of the process is provided as well on page 166.

This description and the remainder of the Article address the process for all migrants who are detained pending ongoing immigration court deportation proceedings and who face no statutory impediment to release. As a result, I do not include those with final deportation orders. ${ }^{17} \mathrm{I}$ also do not include individuals in pending

16. Even the terminology used to describe the custody determination process is often perplexing. References to "bond hearings" or "bond proceedings" are not found in the statute or regulations, but those terms are used to describe the custody determination process. 8 U.S.C. $\S 1226$ (a) (2012) (section titled "Arrest, detention and release"); 8 CFR $§ 236.1$ (c)(8) (2016) (section titled "Apprehension, custody and detention"); EOIR STATISTICS YeARBOOK 2015, supra note 5, at A1 (describing "bond redetermination hearings" and "bonds"); EXEC. OFFICE OF IMMIGRATION REVIEW, supra note 8, at 2 (indiscriminately referencing "bond hearings," "custody hearings," and "bond redetermination hearings"). The term "bond" is sometimes used to describe a particular monetary bond that has been set as a condition on release but is also used more generally to describe the detention/release decision or process. Thus, a decision to detain is often described as a "no bond" decision (which is confusingly the opposite of a decision to release without a bond requirement). In addition, those who are not eligible for a custody redetermination hearing in immigration court are often described as not being "bondeligible" when the limitation on their rights is not about bond but about immigration court review. The use of the term "bail" is also confusing. Sometimes flight risk is described as "bail risk," which suggests that bail is equivalent to release. E.g., Patel, 15 I. \& N. Dec. 666, 667 (B.I.A. 1976), 1976 WL 32348 , at *1. In other instances, the term "bail" is used interchangeably with monetary bond imposed as a condition of release. E.g., San Martin, 15 I. \& N. Dec. 167, 168 (1974), 1974 WL 30025, at *2. Criminal justice commentators have similarly struggled with the terminology surrounding pretrial detention and release determinations and conditions on release. See SCHNACKE, supra note 14, at 99-105.

17. Some detained migrants with a deportation order are removed summarily from the United States under expedited procedures and do not spend extensive periods in detention, 
deportation proceedings who are subject to the mandatory detention statute, which covers migrants who have been convicted of any of a wide range of crimes and migrants certified as presenting terrorism concerns. ${ }^{18}$

\section{A. Initial DHS Custody Determinations}

For migrants who are apprehended and placed into immigration court deportation proceedings, DHS makes an initial decision to detain or to release if the migrant is not subject to mandatory detention. ${ }^{19}$ The initial decision regarding detention usually takes place shortly after apprehension. ${ }^{20}$ However, there are some cases where an individual is initially not eligible for release, generally because of immediate imposition of a deportation order in expedited proceedings, ${ }^{21}$ but then becomes releaseeligible after passing a screening interview that vacates the initial deportation order and places the individual into pending deportation proceedings. ${ }^{22}$ In those cases, DHS makes a custody decision after the individual becomes eligible for release.

DHS has full authority, in its decision, to release an apprehended individual who is not subject to mandatory detention. Most migrants not in mandatory detention fall under 8 U.S.C. $\$ 1226(\mathrm{a})$, which provides in permissive terms that a migrant " $m a y$ be arrested and detained pending a decision on whether the alien is to be removed from the United States." 23 The statute goes on to provide that, after arrest, immigration authorities "(1) may continue to detain the arrested alien; and (2) may release

while others are detained for relatively short periods pending physical removal after a final deportation decision. See 8 U.S.C. § 1225(b)(1)(B)(iii)(IV) (2012) (expedited removal for certain recent arrivals without valid immigration documents); 8 U.S.C. $§ 1231$ (a)(5) (2012) (reinstatement of removal and post-removal detention for those with final orders of deportation); Zadvydas v. Davis, 533 U.S. 678, 701-02 (2001) (requiring presumptive release if detention continues beyond six months after final deportation order); SIMANSKI, supra note 3, at 5 (DHS deported over 350,000 individuals through abbreviated expedited removal and reinstatement of removal proceedings).

18. 8 U.S.C. $§ 1226$ (c) (2012) (requiring detention of migrants convicted of certain criminal offenses); 8 U.S.C. $§ 1226 a$ (2012) (requiring detention of designated suspected terrorists); Demore v. Kim, 538 U.S. 510, 531 (2003) (finding mandatory detention constitutional).

19. 8 U.S.C. $§ 1226(a) ; 8$ C.F.R. $§ 236.1(c)(8)$. Various DHS entities may conduct the initial apprehension, but the DHS subagency known as Immigration and Customs Enforcement (ICE) assumes custody if an individual is ordered detained. Immigration Enforcement: Detention Management, supra note 4; Who We Are: Overview, supra note 4.

20. See 8 C.F.R. $§ 287.3$ (d) (2016) (arrest must be followed in forty-eight hours by decision whether to detain).

21. See 8 U.S.C. $§ 1225(\mathrm{~b})(1)(\mathrm{B})(\mathrm{iii})(\mathrm{IV})$ (requiring detention of individuals in expedited removal).

22. X-K-, 23 I. \& N. Dec. 731, 731 (B.I.A. 2005), 2005 WL 1104422, at*1 (holding that custody redetermination hearings are available to individuals who have left expedited removal and are now in full deportation proceedings seeking asylum). It may be argued that those in expedited removal need not be detained before the screening interview but rather only if they do not pass the interview. See 8 U.S.C. $§ 1225$ (b)(1)(B)(iii)(IV). Regardless, detention is not required after a favorable screening. X-K-, 23 I. \& N. Dec. at 731.

23. 8 U.S.C. $§ 1226$ (a) (emphasis added). 
APPREHENSION AND INITIATION OF IMMIGRATION COURT DEPORTATION PROCEEDINGS

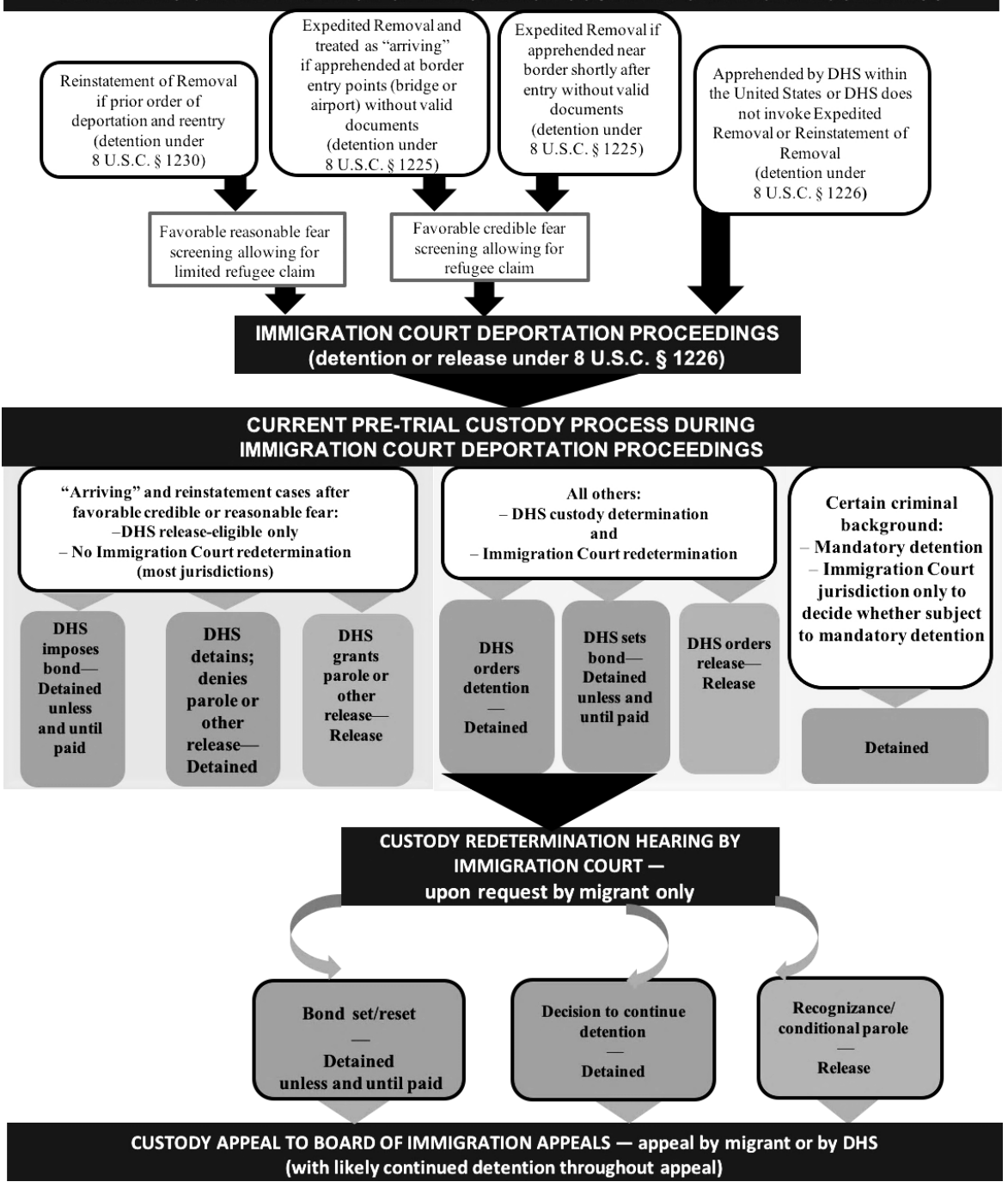

Figure 1. Immigration Custody Determination Process 
the alien ...."24 DHS may release a migrant on recognizance, sometimes known as conditional parole, or under other arrangements, such as placement in a formal alternatives to detention program. ${ }^{25}$

However, DHS only rarely releases a migrant after apprehension in its first decision on custody. ${ }^{26}$ Immigration officials almost always detain arrested individuals for at least some time period as they initiate deportation proceedings in the immigration courts. ${ }^{27}$

When it makes an initial custody determination not to release immediately, DHS may either: (1) order detention directly, without the availability of release on bond; or (2) set a monetary bond, which if paid will result in release. ${ }^{28}$ Where bond is set, a minimum bond amount of $\$ 1500$ is required by law, ${ }^{29}$ but bond is often set much higher with bond amounts nationwide averaging at approximately $\$ 6000 .{ }^{30}$ The bond must be paid in full before the migrant will be released. ${ }^{31} \mathrm{~A}$ decision to require a

24. Id.

25. Id.; Ortega-Cervantes v. Gonzales, 501 F.3d 1111, 1115 (9th Cir. 2007) (noting that "the phrase 'release on recognizance' [is used] as another name for 'conditional parole' under $\S 1226(\mathrm{a}) . ”)$.

26. See, e.g., Eliott C. McLaughlin \& Catherine E. Shoichet, Jose Antonio Vargas, Symbol of Immigration Debate, Freed After Detention, CNN (July 15, 2014), http:// www.cnn.com/2014/07/15/justice/texas-jose-vargas-detained/ [https://perma.cc/RUF3-WW3U] (high-profile journalist released shortly after apprehension as deportation proceedings initiated).

27. See Noferi \& Koulish, supra note 13, at 50 (calculating $91 \%$ detention rate for DHS custody determination); Decisions on ICE Detainees: State-by-State Details, supra note 7 (4\% of detainees released on their own recognizance from initial place of detention).

28. See 8 U.S.C. $\$ 1226(a) ; 8$ C.F.R. $\$ 236.1(c)(8)$ (2016).

29. 8 U.S.C. $\$ 1226($ a) (setting minimum bond of $\$ 1500$ ).

30. AMNESTY INT'L, supra note 6, at 14, 17 (calculating that nationwide average bond amount is almost $\$ 6000$ and providing examples of bonds set at $\$ 25,000$ to $\$ 50,000$ ); Eagly $\&$ Shafer, supra note 6 , at 69 n.220 (noting that authors observed bond amounts ranging from $\$ 1500$ to $\$ 50,000$ and citing other studies finding average bond amounts of anywhere between $\$ 5000$ and \$15,000 in different contexts); Letter from Judy Rabinovitz, Deputy Dir. and Dir. of Detention and Fed. Enf't Programs, ACLU Immigrants' Rights Project, to Leon Fresco, U.S. Dep't. of Justice, Civil Div.-Office of Immigration Litig. (May 11, 2015), https://www.aclu.org/sites/default/files/field_document/rilr_letter_re_high_bonds_for_class _members_5_11_15-signed.pdf [https://perma.cc/RVY2-CS9K] [hereinafter ACLU Letter Regarding High Bonds] (describing a regular ICE practice of setting $\$ 7500$ to $\$ 20,000$ bonds for women detained with their children); Regina Garcia Cano, Huge Rise Seen in ICE Cases Released on Bail, Houston CHRON. (Mar. 24, 2012), http://www.chron.com/news/houston -texas/article/Huge-rise-seen-in-ICE-cases-released-on-bail-3432655.php [https://perma.cc /D37C-8T3N] (calculating an average bond amount of over $\$ 5000$ in 2011).

31. The government does not accept unsecured or deposit bonds, which are sometimes available in the criminal pretrial context and which allow release upon payment of a percentage of the bond or without any payment at the outset, pursuant to a contractual promise to pay the full bond amount only in the case of breach. See 8 U.S.C. § 1226(a) (requiring security); Justice Policy Inst., Bail Fail: Why the U.S. Should END the Practice OF Using Money FOR BAIL 7, 9 (2012) (defining unsecured and deposit bonds). Commercial surety bonds, which consist of a contractual promise by a commercial security entity to pay the bond in case of breach, are available upon payment of a fee to the commercial surety company. See 8 C.F.R. 
bond necessarily involves continued detention for some period of time, at least until bond payment is gathered and presented or the bond decision is reviewed and modified or vacated.

Under current interpretation of the law, some migrants do not undergo the DHS custody determination process as just described, even though they are held pending ongoing deportation proceedings and do not fall within the mandatory detention scheme. This limitation applies most frequently to certain migrants who are initially subject to expedited deportation but then pass a screening interview to establish a refugee claim, which places them into full immigration court deportation proceedings to seek refugee status. Specifically, the limitation applies to asylum seekers apprehended right at the border and treated as "arriving aliens" 32 and to migrants with prior deportation orders who seek asylum-related refugee protection. ${ }^{33}$ According to current interpretation, these individuals do not qualify for a DHS custody determination as such but rather qualify only for "parole" or "supervised release" from detention at DHS discretion. ${ }^{34}$ However, DHS does regularly reach detention determinations in these cases by making a decision whether or not to grant parole or other release, at least where a request for release is presented. ${ }^{35}$

$\S 103.6$ (2016). However, these and other bondsmen mechanisms are rarely used in the immigration detention context. See U.S. ImMigration ANd Customs ENFORCEMENT, U.S. DeP'T of Homeland Sec., Enforcement and Removal Operations Bond Management HANDBOOK 5 (2014) (about 90\% of immigration bonds are paid in full at the outset).

32. See 8 C.F.R. $§ 1003.19(\mathrm{~h})(2)(\mathrm{i})(\mathrm{B})$ (2016); X-K-, 23 I. \& N. Dec. 731 (B.I.A. 2005), 2005 WL 1104422; U.S. IMMIGRATION AND CUSTOMS ENFORCEMENT, ICE POLICY DiRECTIVE No. 11002.1, Parole of Arriving Aliens Found to Have a Credible Fear of PERSECUTION OR TORTURE 2 (2009) [hereinafter PAROLE DiRECTIVE]. The policy for arriving aliens might also apply to other individuals who are not asylum seekers. However, in practice, most arriving aliens who are not asylum seekers are subject to mandatory detention on other grounds. See 8 U.S.C. § 1225(b) (2012) (detention during expedited removal); 8 U.S.C. $\S 1226(\mathrm{c})$ (2012) (mandatory detention on criminal grounds).

33. See 8 U.S.C. $\S 1231(a)(5)$ (2012); 8 U.S.C. $§ 1231(a)(2)-(3)$ (2012). The law is not altogether clear regarding the status of individuals with prior deportation orders who seek refugee protection in deportation proceedings after having passed a screening interview. However, the best interpretation is that these individuals are not subject to a final deportation order, and detention on that basis, because they have pending proceedings that may result in a decision allowing them to remain in the United States. See Guerra v. Shanahan, No. 15-504-CV, 2016 WL 4056035, at *4 (2d Cir. July 29, 2016); Rodriguez v. Robbins (Rodriguez III), 804 F.3d 1060, 1086 (9th Cir. 2015), cert. granted sub nom. Jennings v. Rodriguez, 136 S. Ct. 2489 (2016).

34. See 8 U.S.C.A. § 1182(d)(5) (West 2005 \& Supp. 2016); 8 U.S.C. § 1231(a)(2)-(3) (2012); 8 C.F.R. $\$ 212.5$ (2016); 8 C.F.R. $§ 241.5$ (2016); Inspection and Expedited Removal of Aliens; Detention and Removal of Aliens; Conduct of Removal Proceedings; Asylum Procedures, 62 Fed. Reg. 10312, 10320 (Mar. 6, 1997) (codified in scattered parts of 8 C.F.R.).

35. Commentators often describe these individuals as not bond-eligible or even as subject to mandatory detention. However, that phrasing does not accurately describe the limitation. They can be detained or released, so they are not subject to mandatory detention. E. g., 8 U.S.C. $\S 1225$ (b)(1)(B)(iii)(IV) ("mandatory detention" provision applying only after a failed screening interview); 8 U.S.C. $\$ 1231$ (a)(2) (providing mandatory detention only for individuals found deportable on serious criminal or security grounds); 8 C.F.R. $§ 212.5$ (c)-(d) (allowing and setting conditions for parole when mandatory detention does not apply); 8 C.F.R. $§ 241.5$ 


\section{B. Custody Redetermination by DHS and the Immigration Court}

DHS may always redetermine custody status after the initial DHS custody determination. ${ }^{36}$ In other words, DHS may change a bond amount imposed or order release on recognizance after initially setting a bond. It also may reconsider a denial of parole or order of supervision or modify the terms of a parole or supervision order. ${ }^{37}$

In most cases, the initial DHS custody determination is also subject to a custody redetermination hearing before an immigration court. ${ }^{38}$ The immigration courts are housed within the Executive Office for Immigration Review (EOIR) of the Department of Justice. ${ }^{39}$ The immigration judges are thus separate from DHS but are administrative judges. ${ }^{40}$

A detainee must make an "application" to the immigration judge to obtain this review of the custody determination made by DHS. ${ }^{41}$ The review is not automatic. It usually takes weeks for an immigration court custody redetermination hearing to be

(allowing for release on order of supervision); E-mail from Marlen Piñeiro, Assistant Dir. For Repatriation, \& Philip Miller, Assistant Dir. For Field Operations, to Assistant Dirs., Deputy Assistant Dirs., Field Office Dirs., \& Deputy Field Office Dirs. (July 31, 2014, 2:57 PM) (e-mail obtained through FOIA Response to Andrew Free on file with the Indiana Law Journal) (providing guidance from DHS headquarters to all field offices that detention is not mandatory for individuals with reinstated deportation orders who seek refugee protection); E-mail from Philip T. Miller, Assistant Dir. For Field Operations, to Field Office Dirs. \& Deputy Field Office Dirs. (June 6, 2014, 10:42 AM) (e-mail obtained through FOIA Response to Andrew Free on file with the Indiana Law Journal) (providing guidance from DHS headquarters to all field offices that "mandatory detention" applies in expedited removal only before a favorable credible fear screening and also noting that "arriving aliens" may be released on parole). And a monetary bond may be assessed if DHS decides to release on parole or under supervision, so the possibility of release upon condition of bond payment exists as well. See PAROle Directive, supra note 32, at 7; 8 C.F.R. § 241.5(b); Human Rights First, supra note 6 , at 4 ( $84 \%$ of attorneys responding to a questionnaire indicate that DHS regularly assesses a monetary bond in connection with a grant of parole). These individuals just do not receive a DHS custody determination under 8 C.F.R. $\$ 236.1(\mathrm{c})(8)$, although it is not clear that the statute or regulations preclude application of the same initial DHS custody determination process applied to other detained migrants. See 8 U.S.C. $§ 1226$ (a) (providing for authority to detain or release for all individuals in deportation proceedings); 8 C.F.R. $§ 236.1$ (c)(8) (2016) (providing for initial custody determination for any individual pending deportation proceedings except those subject to mandatory detention on criminal grounds under 8 U.S.C. $\S 1226(\mathrm{c})$ ). As will be discussed below, current interpretation does preclude the possibility for immigration court custody redetermination hearings in these cases. See X-K-, 23 I. \& N. Dec. 731 (B.I.A. 2005), 2005 WL 1104422; 8 C.F.R. $§ 1003.19$ (h)(2)(i)(B) (2016); E-mail from Marlen Piñeiro, supra.

36. 8 C.F.R. § 236.1(c)(8)-(9); 8 C.F.R. § 236.1(d).

37. PAROle Directive, supra note 32 , at 4.

38. E.g., 8 C.F.R. $\S 1003.19 ; 8$ C.F.R. $\S 1236.1(d)$ (2016).

39. About the Office, EXeC. OfFice FOR IMMigration ReVIEW, DeP'T of Justice, http://www.justice.gov/eoir/orginfo.htm [https://perma.cc/2UKV-Y5Z5].

40. 8 C.F.R. $\S 1001.1(1)$ (2016).

41. 8 C.F.R. § 1236.1(d); see P-C-M-, 20 I. \& N. Dec. 432 (B.I.A. 1991), 1991 WL 353532; 8 C.F.R. $\S 1003.19$. 
scheduled after the initial DHS custody determination. ${ }^{42}$ As will be described further below, the review is also limited. ${ }^{43}$ In addition, immigration judge review is provided only on one occasion as of right. Any subsequent requests for review by the immigration judge "shall be considered only upon a showing that the alien's circumstances have changed materially since the prior ... redetermination." 44

Under current law and interpretation, "arriving aliens" and individuals with prior deportation orders are not entitled to immigration judge review of the detention decision made by DHS even after they pass the relevant screening interviews and are seeking refugee status in full immigration court deportation proceedings. ${ }^{45}$ Thus, a DHS decision to detain or to impose conditions on release is not reviewable by any outside adjudicator. The Ninth Circuit has held that some individuals held under this regime for six months or longer must receive the opportunity to obtain immigration court review of custody. ${ }^{46}$ However, the Ninth Circuit's rule is the exception and

42. See, e.g., Declaration of Barbara Hines at 7, R.I.L-R v. Johnson, 80 F.3d 164 (D.D.C. 2015) (No. 1:15-cv-00011-JEB) (describing periods of weeks or months between DHS and immigration court custody determinations in family detention cases). There is often a delay in the request being made, since review is not automatic and there is no specific time limit by which the immigration court must schedule the hearing once requested. See Rodriguez III, 804 F.3d 1060, 1085 (9th Cir. 2015) (noting that migrants may not request an immigration court custody redetermination hearing because they may not be aware of their right to such a hearing and may be "poorly equipped to request one"), cert. granted sub nom Jennings v. Rodriguez, 136 S. Ct. 2489 (2016); EXEC. OfFICE FOR IMMigration Review, IMMigration CourT PRACTICE MANUAL § 9.3(d) (2016), https://www.justice.gov/sites/default/files/pages/attachments /2016/02/04/practice_manual_-_02-08-2016_update.pdf [https://perma.cc/43VS-NQ2F] (noting that the immigration court will schedule a requested hearing for the "earliest possible date"); $c f$. Corley v. United States, 556 U.S. 303, 320-21 (2009) (finding that prompt presentment before a judicial offer is required in the criminal context to ensure a prompt decision on detention or release); Cal. Penal Code $\$ 825$ (West 2008) (requiring arraignment, including decision on detention or release, within 48 hours of arrest except in special circumstances).

43. See infra Part II.A.3.

44. 8 C.F.R. $\S 1003.19($ e).

45. A-W-, 25 I. \& N. Dec. 45, 47-48 (B.I.A. 2009), 2009 WL 8628885, at *2-3 (holding that the immigration courts do not conduct custody redetermination hearings for individuals who do not receive a Notice to Appear as a charging document, which includes individuals with a prior deportation order who are seeking refugee protection); see also 8 C.F.R. $\S 236.1(\mathrm{c})(11) \quad$ (precluding immigration court custody redetermination hearings for individuals identified in 8 C.F.R. $\S 1003.19(\mathrm{~h})(2)(\mathrm{i})(\mathrm{B})) ; 8$ C.F.R. $\S 1003.19(\mathrm{~h})(2)(\mathrm{i})(\mathrm{B})$ (making immigration court custody redetermination hearings unavailable for "arriving" aliens); 8 C.F.R. $\S 1236.1$ (d) (providing for immigration court custody redetermination hearings only for individuals held in detention under 8 U.S.C. $§ 1226(a)$ ); E-mail from Marlen Piñeiro, supra note 35 (setting out interpretation that individuals with prior deportation orders who seek refugee protection are held under 8 U.S.C. $\S 1231$ (b) and noting that generally immigration court custody redetermination hearings are unavailable for this group); 8 C.F.R. $\S 1241.14$ (a) (providing for immigration court custody hearings for migrants held under 8 U.S.C. $\S 1231$ in very limited circumstances that do not apply to individuals seeking refugee protection).

46. Rodriguez III, 804 F.3d at 1074 (holding that immigration judges must provide custody redetermination hearings after six-month detention periods for "arriving" aliens and other 
applies only after detention has become prolonged. It has not led to changes in the rules or practice in other parts of the country.

For migrants who are eligible to seek an immigration court custody redetermination hearing, an appeal of the immigration judge's decision to the Board of Immigration Appeals (BIA) is available. ${ }^{47}$ The BIA is also within the Department of Justice Executive Office for Immigration Review and is the appellate administrative body for adjudication of immigration cases. ${ }^{48}$

Review of the final agency decision regarding custody is generally not available in the federal courts. ${ }^{49}$ The immigration statute specifically states that such detention decisions made by immigration officials are not "subject to review." ${ }^{50}$ A detained migrant's only recourse to the federal courts is through a habeas petition. ${ }^{51}$ Such a petition must challenge the legality of the custody determination. ${ }^{52}$ It does not offer an opportunity for review of the merits of an individual decision to detain or release or the imposition of conditions on release. ${ }^{53}$

\section{The Problem WITH the CUSTODy DeterminAtion ProcesS}

The custody determination process dictates detention or freedom for releaseeligible migrants in pending deportation proceedings. As such, the process must be analyzed in light of the theoretical and constitutional underpinnings that permit but limit immigration detention.

Liberty places a central role in constitutional theory, with freedom from physical restraint at the core of the protections offered.$^{54}$ Liberty is the norm, and deprivation of freedom is the limited exception. ${ }^{55}$ Imprisonment is permitted only as criminal

class members who were not previously granted such hearings); Rodriguez II, 715 F.3d 1127, 1144 (9th Cir. 2013) (finding that class members were likely to succeed on the merits of their claim that a custody redetermination hearing is required after six months for certain individuals who were not previously granted such hearings); see also Guerra v. Shanahan, No. 15-504CV, 2016 WL 4056035, at *4 (2d Cir. July 29, 2016) (affirming grant of habeas providing for custody redetermination hearing in immigration court for individual with prior deportation order).

47. 8 C.F.R. $\S 1236.1(\mathrm{~d})(3)$.

48. Board of Immigration Appeals, EXEC. OFFICE FOR IMMIGRATION REVIEW, U.S. DEP'T OF JUSTICE, http://www.justice.gov/eoir/biainfo.htm [https://perma.cc/64GN-5K84].

49. 8 U.S.C. $\S 1226(\mathrm{e})(2012)$.

50. $I d$.

51. Demore v. Kim, 538 U.S. 510, 517 (2003).

52. See id.; Kambo v. Poppell, No. SA-07-CV-800-XR, 2007 WL 3051601, at *7 (W.D. Tex. Oct. 18, 2007) (detained aliens may bring habeas corpus challenges to the constitutionality of the statutory detention framework).

53. See Kambo, 2007 WL 3051601, at *7 (habeas does not allow for review of discretionary judgments regarding release or bond, including the manner in which judgments are made).

54. See Zadvydas v. Davis, 533 U.S. 678, 690 (2001) ("Freedom from imprisonment - from government custody, detention, or other forms of physical restraint-lies at the heart of the liberty [the Due Process Clause] protects.”); Foucha v. Louisiana, 504 U.S. 71, 80 (1992).

55. United States v. Salerno, 481 U.S. 739, 755 (1987) ("In our society liberty is the norm, and detention prior to trial or without trial is the carefully limited exception."). 
punishment after a conviction or as civil administrative detention justified on other limited grounds. ${ }^{56}$ Because civil detention does not involve a conviction, the Constitution dictates that it must be carefully cabined. Civil detention may only be used where necessary to meet narrow, nonpunitive governmental goals, generally limited to prevention of danger to the community or flight from judicial processes..$^{57}$

It is well accepted that immigration detention is only proper if it is justifiable civil detention, since it is not based on a criminal conviction. ${ }^{58}$ The U.S. Supreme Court has upheld the constitutionality of immigration detention but has also carefully limited its reach. ${ }^{59}$ As with other forms of administrative detention, liberty is the norm and immigration detention is generally only permissible as a means of preventing flight or protecting against danger to the community. ${ }^{60} \mathrm{An}$ individualized determination of the need to detain for these purposes is required. ${ }^{61}$ While the Court has held that Congress may establish mandatory detention for limited periods of time for certain named categories of migrants found to present a particular risk, such automatic and non-individualized detention otherwise contravenes constitutional requirements. ${ }^{62}$

Similarly, in line with U.S. constitutional standards, international human rights law preventing arbitrary detention requires that the government detain migrants only as a last resort. ${ }^{63}$ Detention must be shown to be necessary in an individual case in

56. Id.

57. See id.; Kansas v. Hendricks, 521 U.S. 346, 356-57, 363-64 (1997) (finding civil commitment constitutionally permissible in "narrow circumstances" if no "punitive" objective or intent shown); Addington v. Texas, 441 U.S. 418, 428 (1979) (state power in civil commitment cases is constitutional if not exercised in a "punitive sense").

58. Zadvydas, 533 U.S. at 690-92 (holding that immigration detention is civil detention that requires strong justification, usually in the form of flight risk or danger to the community); Reno v. Flores, 507 U.S. 292, 313 (1993) (requiring individualized justification for immigration detention); Sopo v. U.S. Att'y Gen., No. 14-11421, 2016 WL 3344236, at *10 (11th Cir. June 15, 2016) (noting that even mandatory immigration detention is "civil detention" and involves a "profound liberty interest"); R.I.L-R v. Johnson, 80 F.3d 164, 187 No. 15-11 (D.D.C. 2015) (immigration detention is "undisputedly civil" and so must be justified on nonpunitive grounds); Dora Schriro, ImMigration and Customs EnF'T, U.S. DeP'T of Homeland Sec., ImMigration Detention Overview and ReCommendations 4 n.2 (2009) (emphasizing that ICE detention is civil, not criminal).

59. Zadvydas, 533 U.S. at 690 (liberty may be restricted only where "a special justification" exists to outweigh an individual's liberty interest).

60. Id. at 690-92; Guerra, 24 I. \& N. Dec. 37, 38 (B.I.A. 2006), 2006 WL 3337627, at*1 (stating that immigration detention determinations are made in reference to flight risk and danger to the community); R.I.L-R, 80 F.3d at 188-90; (finding that flight risk and danger are the main permissible justifications for immigration detention and that deterrence of further migration is likely not a permissible justification because it sounds in criminal law); Cole, supra note 10, at 1006-10 (highlighting these two principle justifications for civil detention derived from U.S. case law-flight risk or danger to the community).

61. Demore, 538 U.S. 510, 531-32 (2003) (Kennedy, J., concurring).

62. See id. at 514 n.3, 518, 526-27 (permitting only limited mandatory pretrial detention); $i d$. at 532 (Kennedy, J., concurring) (establishing that "individualized determination as to . . risk of flight and dangerousness" would be necessary for longer detention periods); Reno, 507 U.S. at 313 (requiring some level of particularized determination in custody decisions).

63. E.g., International Covenant on Civil and Political Rights (ICCPR), art. 9(1), opened for signature Dec. 19, 1966, 999 U.N.T.S. 171 (entered into force Mar. 23, 1976) ("Everyone 
order to meet a valid and nonpunitive governmental goal, usually relating to flight risk or danger. ${ }^{64}$

As currently configured and implemented, the immigration pretrial custody determination process fails to fulfill a safeguarding role to ensure that liberty is protected and detention is limited to those circumstances when it is necessary in individual cases. The system thus fails to comport with constitutional and human rights limitations on deprivation of liberty.

As will be discussed further in the remainder of this Part, there are two central problems. The first problem is that the custody determination process does not

has the right to liberty and security of person. No one shall be subjected to arbitrary arrest or detention."); Organization of American States (OAS), American Declaration of the Rights and Duties of Man art. I, Apr. 30. 1948, KAV 7225 ("Every human being has the right to ... liberty ...."); $i d$. art. XXV (entitling section "Right of protection from arbitrary arrest"); IACHR Report on Detention, supra note 2, at II 38 (requiring "exceptionality of pre-trial detention"); United Nations High COMm'R FOR Refugees, Detention Guidelines: Guidelines on the APPlicable Criteria and Standards Relating to the Detention of Asylum-Seekers AND Alternatives to Detention, Guideline 4.1 (2012) [hereinafter UNHCR Detention Guidelines], http://www.unhcr.org/en-us/publications/legal/505b10ee9 /unhcr-detention-guidelines.html [https://perma.cc/DFC8-7NWL] ("Detention is an exceptional measure"); United NATiONS High COMM'R FOR REFUgeEs, DETENTION OF REFUgeES AND ASYluM-SEEKERS: CONCLUSION No. 44 (XXXVII) (Oct. 13, 1986) (detention of asylum seekers should "normally be avoided"); Human Rights Comm., A v. Australia, Communication No. 560/1993, U.N. Doc. CCPR/C/59/D/560/1993, II 9.2 (Apr. 3, 1997) (" $[R]$ emand in custody could be considered arbitrary if it is not necessary in all the circumstances of the case ...."). The United States is bound by these international human rights norms. The United States has ratified the ICCPR, which makes that instrument binding if not self-executing. See Louis Henkin, Foreign AfFairs And the United States CONSTITUTION 203 (2d ed. 1996) (noting that, "[w]hether a treaty is self-executing or not, it is legally binding on the United States"). The United States has also ratified the United Nations Refugee Convention, which is the instrument interpreted by UNHCR in its Detention Guidelines and other guidance on detention of asylum seekers. See United Nations Convention Relating to the Status of Refugees, July 28, 1951, 189 U.N.T.S. 137 (entered into force for the United States in 1968 through accession to the Protocol Relating to the Status of Refugees, Jan. 31, 1967, 606 U.N.T.S. 267). Through its membership in the OAS and ratification of the legally binding OAS Charter, the United States accepted obligations to protect the human rights set forth in the American Declaration of the Rights and Duties of Man, which is interpreted by the Inter-American Commission on Human Rights and the Inter-American Court of Human Rights. See Charter of the Organization of American States , art. 3(1), Apr. 30, 1948, 2 U.S.T. 2394, 119 U.N.T.S. 3. (as amended through 1993) (ratified by the United States in 1951); Workman v. United States, Case 12.261, Inter-Am. Comm'n H.R., Report No. 33/06, II 70 (2006), http://cidh.org/annualrep/2006eng/USA.12261eng.htm [https://perma.cc/9QW6 -8VVD].

64. See Human Rights Comm., A, U.N. Doc. CCPR/C/59/D/560/1993, at II 9.4 (holding that the grounds for immigration detention must be "particular to . . individual[s]"); UNHCR DETENTION GUIDELINES, supra note 63, at TII 18-19, 21-30, 47(v) (providing that decisions to detain must be based on a "detailed and individualised assessment" and must be justified for public order or security reasons, usually where there is a risk that the asylum seeker will abscond or an objective security threat); IACHR REPORT ON DETENTION, supra note 2, at III 39, 102 (accepting the need to ensure that an individual reports for immigration court proceedings and protection of public safety as justifications for detention). 
function to make an individualized assessment of the need to detain a particular migrant before depriving an individual of liberty. Much less does it guarantee review to ensure that the decision regarding detention is justified. Instead, the process defaults to detention for at least some period and focuses on setting monetary bond amounts as a condition of eventual release. Detention, even if relatively brief, runs afoul of liberty principles if not anchored in an individualized determination of need. ${ }^{65}$ Once detention is begun on a default basis, however, it also readily becomes prolonged and may last throughout the immigration court deportation proceedings.

Eventual release is limited, largely because bonds present a second problem. The potential for eventual release after payment of a bond does not adequately protect against unjustified deprivation of liberty given the starting place that presumes detention. The bond system is borrowed from the criminal justice system, yet the criminal justice system has moved away from the use of monetary bonds because of the impediment to liberty that they create even where detention is not necessary to prevent flight or danger. Criteria borrowed from the criminal justice system nominally guide the bond decision, but these criteria were not intended for the purpose of determining bond amounts and have not been tested for relevance in the immigration system. Bond amounts are set arbitrarily. The bondsetting process thus results in continued detention of many migrants who do not present a flight risk or danger and should be at liberty.

\section{A. Lack of Individualized Determination of the Need To Detain as a Safeguard for Liberty}

Scholars and advocates alike have condoned the custody determination process in juxtaposition to the much-maligned mandatory detention framework. Mandatory detention has been consistently criticized for imposing detention lacking in individualized consideration and review, such that detention is not justified and may become unnecessarily prolonged ${ }^{66}$ Commentators hold out the custody determination process, in contrast, as the mechanism that allows for individualized determinations

65. See, e.g., Demore, 538 U.S. at 532-33 (Kennedy, J., concurring) (finding detention constitutional where there is a congressional determination that special justification exists for detention of certain categories of migrants but limiting such justification to a "reasonable" period and otherwise affirming the requirement of individualized determination of the necessity of detention without regard to length); Zadvydas, 533 U.S. at 690 (indefinite immigration detention only permissible where "special justification" exists; emphasizing problematic nature of "indefinite" detention of individuals subject to final deportation order only because special justification weakens over time in such cases as physical deportation becomes increasingly unlikely). As discussed further below, even limited periods of detention have serious negative consequences. See infra notes 178, 260-64 and accompanying text.

66. See, e.g., Rodriguez II, 715 F.3d 1127, 1136-44 (9th Cir. 2013) (holding that mandatory detention is unlawful if it becomes prolonged without an individualized determination of justification for detention and ordering individualized detention hearings for migrants held under a mandatory detention regime for six months or longer); Heeren, supra note 11, at 60204 (describing prolonged detention of migrants in mandatory detention and unavailability of procedures for challenging detention); Cole, supra note 10, at 1026 (noting that mandatory detention results in unjustified detention lacking in an adequate individualized determination 
regarding detention, with the opportunity for review and release from detention. ${ }^{67}$ The custody determination process is expected to determine the need to detain based on specific objective considerations of flight risk or danger to the community presented by a particular migrant. Even international human rights bodies, which have insisted on stringent limitations on immigration detention, generally countenance the availability of bond as a means for securing release from detention for migrants. ${ }^{68}$

However, a closer look reveals that the custody determination process in the U.S. immigration system does not offer individualized consideration and review of the need for detention. Instead, the custody determination process for release-eligible migrants in pending deportation proceedings has followed a path similar to mandatory detention. While individual custody decisions are issued in cases of releaseeligible migrants in deportation proceedings, those decisions are not based on individual characteristics of the migrants justifying detention. Instead, the system defaults to deprivation of liberty based on standards and practices that presume that release-eligible individuals in deportation proceedings should and will be detained as a baseline. The limited review available fails to resolve the problem, because it does not direct the inquiry into the necessity of detention in a particular case in order to invalidate detention where unjustified and secure release. The promise of individualized determinations and review of custody are thus illusory, making detention of release-eligible migrants essentially automatic for at least some period and putting liberty beyond reach for too many.

\section{Development of Detention as a Default}

These problematic features of the custody determination process for releaseeligible migrants, who are awaiting hearings and a decision in immigration court deportation proceedings, are of relatively recent vintage. Traditionally, in line with constitutional standards, pretrial immigration detention was the exception rather than the rule. The case law of the BIA held that: "An alien generally is not and should not

of the need for detention); Legomsky, supra note 11, at 546-49 (noting the likelihood that mandatory detention will lead to unnecessary detention).

67. E.g., Kalhan, supra note 10, at 45, 48, 54 (favorably contrasting "individualized bond hearings" with mandatory detention schemes); Legomsky, supra note 11, at 549 (urging caseby-case custody determinations rather than mandatory detention); Margaret H. Taylor, Dangerous by Decree: Detention without Bond in Immigration Proceedings, 50 LoY. L. REV. 149, 170-71 (2004) (urging the requirement of a "bond hearing" in the face of efforts to expand mandatory detention and no-bond mandates); Eunice Lee, Coast to Coast, Federal Courts Say NO to Mandatory Lock-up of Immigrants, AMERICAN CIVIL LiBERTIES UNION (May 22, 2014), https://www.aclu.org/blog/immigrants-rights/coast-coast-federal-courts-say-no -mandatory-lock-immigrants [https://perma.cc/SBY5-S8DX] ("Fortunately, thanks to ACLU's victories, immigrants picked up by ICE in their communities must now be given the basic due process of a bond hearing.").

68. See, e.g., François Crépeau (Special Rapporteur on the Human Rights of Migrants), Rep. of the Special Rapporteur on the Human Rights of Migrants, III 53, 56, 59, U.N. Doc. A/HRC/20/24 (Apr. 2, 2012) [hereinafter Special Rapporteur 2012 Report] (citing with approval bail and bond systems in various countries); UNHCR DETENTION GUIDELINES, supra note 63 , at Guideline 4. 
be detained or required to post bond except on a finding that he is a threat to the national security, or that he is a poor bail risk." ${ }^{69}$ Even when the immigration laws began to favor detention over release for certain individuals with criminal convictions, there was still a robust presumption against detention for all other migrants. ${ }^{70}$ In addition, decisions to detain or impose bond received meaningful review. ${ }^{71}$

Then, in 1996, fueled by politics urging "get tough" measures in immigration and criminal systems alike, Congress adopted legislation that prioritized an enforcement approach to immigration. ${ }^{72}$ The legislation expanded mandatory detention to broad categories of migrants in deportation proceedings who had criminal histories. When mandatory detention became the law for certain groups of migrants, the custody determination process for those not subjected to mandatory detention changed its character as well.

New regulations addressing detention for release-eligible migrants were adopted in 1997 at the same time as adoption of regulations to implement the 1996 mandatory detention law. ${ }^{73}$ The 1997 regulations reversed the prior rule requiring release of a migrant absent an individual finding of significant flight risk or danger to the community. Notwithstanding constitutional principles treating liberty as the rule, the regulations now imposed a presumption of detention, with the possibility of a migrant making a showing of low risk sufficient to persuade an immigration officer to release. ${ }^{74}$ The same regulation also confirmed that "arriving aliens" seeking asylum and those with prior deportation orders would be detained and might be released only exceptionally. ${ }^{75}$

The regulations that govern initial custody determinations, after adoption of the 1997 regulations, thus specifically provide that DHS should not release a detained migrant, unless the migrant "demonstrate[s] to the satisfaction of the officer" that he or she would not pose a danger or a likelihood of absconding. ${ }^{76}$ This standard does more than simply allocate the burden of proof for a custody determination to the

69. Patel, 15 I. \& N. Dec. 666, 666 (B.I.A. 1976) (citations omitted), 1976 WL 32348, at *1.

70. See Drysdale, 20 I. \& N. Dec. 815, 816-17 (B.I.A. 1994), 1994 WL 232084, at *2 (establishing presumption of detention for individuals convicted of an aggravated felony, but not others, and still requiring release upon a showing of lack of flight risk or danger to the community).

71. Gilboy, supra note 8, at 553 ("Immigration judges play an extremely active role in review of . . bail decisions.").

72. Illegal Immigration Reform and Immigrant Responsibility Act of 1996, Pub. L. No. 104-208, Div. C, 110 Stat. 3009-546 (codified as amended in scattered sections of the U.S.C.); Antiterrorism and Effective Death Penalty Act of 1996, Pub. L. No. 104-132, 110 Stat. 1214 (codified as amended in scattered sections of the U.S.C.); Jonathan S. Landay, Legal Immigrants Deported if They Have a Criminal Past, CHRISTIAN SCI. Monitor (Sept. 5, 1996), http://www.csmonitor.com/1996/0905/090596.us.us.4.html [https://perma.cc/G7CE-UN9V] (noting the role of "strong anti-immigrant and get-tough-on-crime sentiments that have emerged around the country" in the adoption of the 1996 legislation).

73. 62 Fed. Reg. 10312, 10323 (1997).

74. Id.

75. Id. at 10320 (for arriving asylum seekers, "discretion to release from custody will [be] on a case-by-case basis"); $i d$. at 10326, 10379 (reaffirming detention for cases involving a prior removal order regardless of refugee claim).

76. 8 C.F.R. $\S 236.1(c)(8)$ (2016). 
migrant, which might be problematic on its own. ${ }^{77}$ It allows, or more accurately requires, detention without resolution of the threshold question of whether a risk of flight or danger to the community requiring detention exists. Individualized consideration of flight risk and danger become relevant only in determining whether DHS would consider subsequent release based on a migrant's showing and, if so, in setting conditions to be met for such release to occur.

The immigration authorities acknowledged the change wrought in $1997 .^{78}$ The new rule was explicitly intended to achieve "increased detention."79

The BIA soon reversed its previous course as well and directed the immigration courts to follow the new legal standard presuming detention. ${ }^{80}$ Determinations regarding the need to detain in release-eligible cases thus went the direction of mandatory detention cases.

This outcome was not required, or permitted, by the 1996 legislation or by constitutional developments that took place in the legislation's aftermath. The 1996 legislation did not alter the statutory provisions allowing for release of individuals not subject to mandatory detention. And, in 2001, the Supreme Court confirmed the presumption of liberty in the immigration context in its Zadvydas v. Davis decision and insisted that immigration detention must be justified in an individual case. ${ }^{81}$ Further, in its Demore v. Kim decision upholding the 1996 mandatory detention legislation, the Supreme Court established that mandatory detention is a carve-out to the general detention regime. ${ }^{82}$ The Court confirmed that mandatory detention was intended to affect only a specific "subset" of people who are deportable based on certain crimes, leaving the detention regime otherwise intact. ${ }^{83}$ In its approval of mandatory detention in Demore, the Supreme Court specifically noted that the categorical approach to detention applied only, for a brief detention period, to a "limited class" of migrants that Congress deemed to present a particular flight risk or danger to the community based on available information. ${ }^{84}$ In doing so, the Court reaffirmed the importance of the requirement of individualized determinations

77. See Das, supra note 9, at 156-58 (suggesting that placing the burden of proof on the migrant is problematic from an institutional design perspective because the migrant does not have access to necessary information and immigration authorities need greater incentives to develop the relevant information).

78. 62 Fed. Reg. at 10323 (noting the reversal of the presumption).

79. $I d$.

80. Guerra, 24 I. \& N. Dec. 37, 38 (B.I.A. 2006), 2006 WL 3337627, at *1 (“An alien in a custody determination . . . must establish to the satisfaction of the Immigration Judge and this Board that he or she does not present a danger to persons or property, is not a threat to the national security, and does not pose a risk of flight."); Adeniji, 22 I. \& N. Dec. 1102, 111213, 1116 (B.I.A. 1999), 1999 WL 1100900, at *10, 12 (holding that the regulations require a migrant seeking release in a custody redetermination hearing to "demonstrate" lack of flight risk and danger to the community).

81. 533 U.S. 678, 690-91 (2001).

82. 538 U.S. 510, 518, 521 (2003) (emphasizing that mandatory detention is a Congressional mandate that applies only to a "limited class" or "subset" of deportable individuals).

83. Id. at 521 .

84. Id. at 518-20; see also id. at 526 (describing the mandatory detention statute as a "narrow" detention policy). 
justifying detention, based on flight risk or danger to the community, as the general rule. ${ }^{85}$ The courts have never approved the constitutionality of a broad presumption of detention for release-eligible individuals. ${ }^{86}$

If anything, the legislative expansion of mandatory detention should have led to reinforcement of the existing system of presumptive release and individualized determinations regarding detention in all release-eligible cases as a counterweight to mandatory detention. In this way the overall immigration detention regime would be aligned with the limited acceptable purposes of civil immigration detention. ${ }^{87}$ After all, the expansion of mandatory detention made it likely that migrants who presented a serious danger or flight risk, along with many who might not, would already be subject to mandatory detention. Those remaining eligible for release would be least likely to present individual factors suggesting the need for detention.

Nevertheless, the "get tough" turn in immigration enforcement and the resulting 1997 regulatory regime set a tone and legal framework for detention of releaseeligible migrants as an automatic default. This shift allowed and encouraged additional detention-focused developments and implementation practices described below. As a result, unjustifiably broad detention of release-eligible migrants has become the norm.

\section{Non-Individualized Presumptive Detention in Initial DHS Custody Determinations}

\section{a. DHS Implementation of Detention as Default}

Pursuant to the 1997 regulatory framework, DHS issues a decision to detain in its initial custody determination in most cases. Detention is the default, which means that detention is the result of DHS custody determination decisions; release is the unusual exception. There is no meaningful inquiry into the need to detain to address individualized flight or danger risks before detention, beyond initial apprehension and processing, takes place. ${ }^{88}$ Detention is automatic in a way that necessarily contravenes basic liberty principles requiring individualized determination of necessity.

85. See id. at 531-32 (Kennedy, J., concurring) (limiting mandatory detention to cases where the government has established a likelihood of removability and noting that "ordinary bond procedures" would otherwise apply to determine whether a migrant "would pose a risk of flight or a danger to the community" if released).

86. See Sopo v. U.S. Att'y Gen., No. 14-11421, 2016 WL 3344236, at *30 (11th Cir. June 15, 2016) (Pryor, J., concurring in part and dissenting in part) ("[N]either the Supreme Court nor this circuit has ever before addressed whether the regulations governing [detention for release-eligible individuals subject to 8 U.S.C. 1226(a)] satisfy due process requirements."); Prieto-Romero v. Clark, 534 F.3d 1053, 1066 (9th Cir. 2008) (finding it unnecessary to reach the issue in the only case directly challenging the regulation that places the burden regarding release on the migrant).

87. See Zadvydas v. Davis, 533 U.S. 678, 690-91 (2001).

88. The decision to detain is distinct from the original decision to apprehend. See 8 C.F.R. $\S 287.3$ (d) (2016) (noting that arrest must be followed in forty-eight hours by decision whether to continue in custody). DHS may initially apprehend a migrant and place that individual in immigration court deportation proceedings but should not detain without an individualized determination that such detention is necessary. 
To understand this result, it is critical to consider the binary detention/release decision as the central liberty issue. In other words, the focus of the analysis must be on whether the DHS custody determination results in release or results in continued detention, even if only for some period of time. Detention beyond initial apprehension necessarily constitutes a deprivation of liberty even if release is later secured. On this binary, detention is the result in almost all cases as seen upon further analysis of the possible results of the initial DHS custody determination. ${ }^{89}$

As noted above, the DHS decision after apprehension may be simply to continue detention, which would be the presumptive option under the regulation. ${ }^{90}$ Alternatively, the decision may be to detain until certain conditions are fulfilled that will allow for release, almost always payment of a monetary bond. This decision will also result in detention for at least a period of time until the bond condition is paid or modified. In effect, a decision of detention with the possibility of release on bond is a decision to detain for at least some period, which often becomes detention for a prolonged period or throughout the deportation proceedings. ${ }^{91}$ The government has acknowledged that such a decision, setting a bond requirement, is one of detention, albeit allowing for the possibility of release after payment of the bond ${ }^{92}$ In the criminal justice context, analysts have similarly clarified that a decision to impose bond is "not release." "93 Thus, as a binary detention/release question, the first two possible

89. See U.S. DeP'T of Homeland Sec., Form I-286: Notice of Custody DETERMINATION (providing for DHS to indicate detention, to set a particular bond amount as a condition of release, or to order release on "recognizance").

90. This determination is often referred to as a "no bond" decision. However, it is more accurate to identify its fundamental nature as a decision to detain rather than as a decision regarding bond. DHS regularly issues such decisions to detain without the possibility for release on bond in its initial custody determination. See HuMAn Rights FirST, supra note 6, at 25 (reporting results of attorney survey which found that DHS regularly makes such detention decisions across the board in certain facilities).

91. See, e.g., NYIRS Report, supra note 7, at 13 (almost $50 \%$ of migrants who received a decision allowing release on bond remained detained because of inability to pay). In practice, in the author's experience, even when an affordable bond is assessed by ICE or the immigration court and the detainee's family is prepared to pay it, the migrant remains detained for an additional period, often extending days or even weeks, while the logistics and paperwork of bond payment and release take place. The period of detention may be cut short through an immigration court custody redetermination decision on review that orders release on recognizance or on an affordable bond. However, the limits on immigration court review described below substantially weaken this possibility. See infra Part II.A.3.

92. E.g., OfFice of InsPector Gen., U.S. DeP'T OF Homeland SEC., OIG-15-22, U.S. ImMigration AND Custom Enforcement's Alternatives to DETENTION (REvised) 25 (2015) [hereinafter OIG REPORT ON ALTERNATIVES TO DETENTION] (clarifying that bond eligibility is considered after a decision to detain is made); U.S. DEP'T OF HoMELAND SEC., DHS/ICE/PIA-015(d), PRIVACY IMPACT ASSESSMENT UPDATE FOR THE ENFORCEMENT INTEGRATEd DATABASE (EID), Risk ClassifiCATION AsSESSMENT (RCA 1.0), ENFORCE Alien Removal Module (EARM 5.0), And Crime Entry Screen (CES 2.0) 4-5 (2012) [hereinafter RISK CLASSIFICATION ASSESSMENT], http://www.dhs.gov/xlibrary/assets/privacy /privacy_piaupdate_EID_april2012.pdf [https://perma.cc/3ZXV-2J2P] (same).

93. Timothy R. Schnacke, Nat'L Inst. OF CorR., U.S. DeP'T of Justice, Money as a Criminal Justice Stakeholder 64 (2014); see also Marie VanNostrand, NAT'L Inst. of Corr., Dep't of Justice, Legal and Evidence-Based Practices: ApPlications of Legal 
DHS determinations regarding custody are decisions to detain. DHS generally adopts one of these two determinations in its initial custody determination and so detains.

The DHS custody determination might instead result in a decision to release on recognizance (also known as conditional parole), which would be the only decision on the binary that would not result in detention and would instead lead to immediate release. ${ }^{94}$ Such a decision could contain conditions on release, such as reporting requirements, that could be imposed after release and would not require continued detention. However, with a default of detention, it is rare for migrants to be released on their own recognizance or conditional parole. The data is very limited but suggests that only $1-9 \%$ of DHS detainees are released directly on their own recognizance or conditional parole without the requirement of a monetary bond..$^{95}$ Outright release is

PrinciPles, LaWs, AND Research to the Field of Pretrial Services 18-19 (2007) (noting, in the criminal pretrial detention context, that often the "outcome is detention" when bonds are imposed).

94. See 8 U.S.C. § 1226(a) (2012) (referencing "conditional parole").

95. NYU School of Law Immigrant Rights Clinic, Immigrant DefEnSE Project \& FAmilies for Freedom, Insecure Communities, Devastated Families: New Data on Immigrant Detention and Deportation Practices in New York City 10 (2012) [hereinafter INSECURE COMMUNITIES] (migrants detained in the New York City area were released on their own recognizance in less than $1 \%$ of cases; defendants in the criminal justice system were thirty-seven times more likely to be released on their own recognizance); Detainees Leaving ICE Detention from the South Texas Contract Detention Facility, TRAC IMMIGRATION, http://trac.syr.edu/immigration/detention/201509/STCDFTX/exit/ [https://perma.cc /44D6-NGQ7] (at one of the largest immigration detention centers in the country, only 43 out of 9510 detainees leaving DHS custody in 2015 were released on recognizance set either by DHS or by an immigration judge; a total of only $1.9 \%$ of detainees left the facility on a grant of recognizance, parole, or order of supervision); Decisions on ICE Detainees: State-by-State Details, supra note 7 (noting that, nationally, $4 \%$ of detainees were released on their own recognizance from initial place of detention and $6.6 \%$ were released on their own recognizance at some point during their detention from November to December of 2012). Government data for fiscal year 2013 reports that 662,000 migrants were apprehended, SIMANSKI, supra note 3, at 1 , with just under 30,000 released on their own recognizance, which is a $4 \%$ rate of release on recognizance, U.S. Gov't AcCountability OfFice, GAO-15-26, Alternatives to Detention: Improved Data Collection and Analyses Needed To Better Assess Program EfFectiveness 8 (2014) [hereinafter GAO, Alternatives to Detention]. Even then, the data does not show whether the release on recognizance took place immediately after apprehension or after some period of detention during pending deportation proceedings. See GAO, ALTERNATIVES TO DETENTION, supra, at 8. Including releases on parole and alternatives to detention, which do not always qualify as releases on recognizance because they often involve a monetary bond, the percentage rises only to $9 \%$. See id. (providing data showing that approximately 60,000 migrants were released on recognizance, parole or alternatives to detention). These percentages are based on releases as a portion of total numbers of apprehensions, rather than just release-eligible pretrial detainees; the release numbers may therefore include some individuals subject to final orders or mandatory detention who are not the focus of this Article. The percentage of those released without a bond requirement would likely be higher if it were possible to consider a smaller baseline group of only those who are eligible for release in pending deportation proceedings. The statistics nonetheless establish the rarity of decisions releasing without a monetary bond requirement. 
extremely unlikely, then, and the DHS initial custody determination decision is thus one of detention.

DHS also defaults to detention for the subset of release-eligible migrants- "arriving" asylum seekers and those with prior deportation orders - who are in pending deportation proceedings but do not fall directly under the general regime for a DHS custody determination. ${ }^{96}$ Under the regulations and guidance applicable in these cases, DHS does not make a determination of the need to detain on an individualized basis after apprehension; instead, detention is explicitly automatic. ${ }^{97}$ DHS may subsequently decide to release at its discretion, but only after detention is automatically imposed..$^{98}$ For "arriving" asylum seekers, a policy memorandum from 2009 requires consideration of release after a favorable screening interview, but only where the asylum seeker "establishes to the satisfaction of [the DHS officer] his or her identity and that he or she presents neither a flight risk nor danger to the community." ${ }^{\prime 99}$ The presumption is one of detention even at the point when DHS may consider release. A monetary bond may also be imposed before release will be secured, both for "arriving" asylum seekers and those with prior deportation orders seeking refugee protection. ${ }^{100}$ So the DHS custody decision generally leads to continued detention for at least some time for these groups as well. ${ }^{101}$

Thus, under the applicable regulatory framework, the initial DHS custody determination results in a decision to detain, after apprehension, for almost all releaseeligible migrants in pending immigration court deportation proceedings. ${ }^{102}$ And, because there is no mechanism for immediate and automatic review of the detention, the migrant is held firmly in custody under this initial determination, for at least some period.

\section{b. DHS Policy and Practice Leading to Non-Individualized Detention Decisions}

DHS policy and practice in making initial custody determinations further ensures automatic resort to detention for release-eligible migrants pending adjudication of

96. See supra notes $45-46$ and accompanying text.

97. 8 C.F.R. $§ 241.3$ (2016); 8 C.F.R. § 235.3(c) (2016); 62 Fed. Reg. 10312, 10320 (Mar. 6, 1997) (codified in scattered sections of 8 C.F.R.).

98. 8 C.F.R. § 212.5(b) (2016); 8 C.F.R. § 235.3(c); 8 C.F.R. § 241.5 (2016).

99. PAROle DireCtive, supra note 32 , at 3.

100. Id. at 7; 8 C.F.R. $\S 241.5(\mathrm{~b})$.

101. See, e.g., Strengthen and Fortify Enforcement (SAFE) Act: Hearing on H.R. 2278 Before the H. Comm. On the Judiciary, 113th Cong. 109 (2013 (statement of Mary Meg McCarthy, Executive Director, National Immigrant Justice Center) (noting that release of asylum seekers under parole memo is limited); HUMAN RIGHTS FIRST, supra note 6, at 13 (noting that parole was not granted in 53\% of cases of "arriving alien" asylum seekers who had passed the asylum screening interview in 2015); David HaUsman, ACLU ImMigRant Rights' PRoJeCt, FACt SHEET: WithHOLdING-ONLy CASES AND DETENTION 2 (2015), https://www.aclu .org/fact-sheet/fact-sheet-withholding-only-cases-and-detention [https://perma.cc/HP3K-LAKS] (finding that migrants with prior deportation orders seeking refugee protection remained detained throughout their deportation proceedings in over $85 \%$ of cases).

102. See Noferi \& Koulish, supra note 13, at 50 (calculating $91 \%$ detention rate by DHS in initial custody determination, based on analysis of government documents, while noting that an important percentage of migrants included in this figure were subject to mandatory detention). 
their cases. The considerations weighed by DHS in implementing its custody determination mandate frequently bear little relation to the need to detain a particular individual in order to address flight risk or danger and instead push towards a detention decision regardless of justification.

DHS often detains to fill the physical space available for detention of migrants. Bed space has always impacted immigration detention decisions. ${ }^{103}$ However, in the past, detention availability was limited, requiring release without a serious individualized assessment of risk in some cases. ${ }^{104}$ Now, the opposite is true. Increased funding of immigration enforcement has led to an exponential increase in the space available for immigration detention in the United States; from 1995 to 2014, the number of daily funded beds increased from 7500 to $34,000 .{ }^{105}$ By the government's own admission, there are generally more beds available than individuals who require detention based on an established flight risk or danger to the community. ${ }^{106}$ Thus, even if an individualized determination would reveal no need for detention, the official making the final decision is hard-pressed to execute release if bed space is currently

103. Demore v. Kim, 538 U.S. 510, 519 (2003) (citing legislative history establishing that funding and detention space limitations affected release determinations); HARWOOD, supra note 12 , at 120-21 (noting varying detention rates in different jurisdictions based on available detention space).

104. See HARWOOD, supra note 12, at 120-21 (in immigration areas having limited space, individuals might be released even if they "lacked the equities normally needed to qualify for release").

105. See Alison Siskin, Cong. Research Serv., Rl32369, Immigration-Related Detention: CurRent Legislative Issues 12 (2012); SChriro, supra note 58, at 2; U.S. IMMigRation AND CuSTOMS ENFORCEMENT, U.S. DEP'T OF HOMELAND SECURITY, FisCAL YEAR 2015 CONGRESSIONAL BUdGET JUSTIFICATION, U.S. IMMIGRATION AND CUSTOMS ENFORCEMENT SALARIES AND EXPENSES 42 (2015), https://www.dhs.gov/sites/default/files /publications/DHS-Congressional-Budget-Justification-FY2015.pdf [https://perma.cc/PDR8 -4JTB] [hereinafter 2015 ICE BUDGET REQUEST] (page 1290 in full version of DHS Budget Request).

106. 2015 ICE Budget ReQuest, supra note 105, at 4, 40 (pages 1252 and 1288 in full version of DHS Budget Request) (seeking appropriations for fewer beds in 2015 than in previous years and stating that these beds will be sufficient to accommodate priority high-risk detainees). The increased bed space is therefore not attributable to an increase in the number of individuals who are likely candidates for detention. This point is further borne out by the statistics showing that the number of undocumented immigrants in the United States who would be subject to detention and deportation and the number of unauthorized border crossers have decreased in recent years rather than increased. See U.S. BordER PATROL, TOTAL ILlEGAL AliEN APPREHENSIONS BY MONTH, https://www.cbp.gov/sites/default/files/documents /BP\%20Total\%20Monthly\%20Apps\%20by\%20Sector\%20and\%20Area\%2C\%20FY2000-FY2015 .pdf [https://perma.cc/8UYF-9GLY] (reporting over 1.6 million unlawful border crossers apprehended in fiscal year 2000 and only 337,117 apprehensions in fiscal year 2015); ANA Gonzalez-Barrera, Pew Research Center, More Mexicans Leaving Than Coming to THE U.S. 5-6 (2015) (showing net loss of Mexican migrants, who make up the largest nationality group subject to detention and deportation proceedings, from 2009 to 2014); Robert Warren, US Undocumented Population Drops Below 11 Million in 2014, with Continued Declines in the Mexican Undocumented Population, 4 J. ON Migration \& HuM. SECURITY 1, 1 (2016) (undocumented population in the United States has declined steadily since 2008 and, in 2014, fell below 11 million for the first time since 2004). 
available and there are no other migrants to be detained with more serious indicia of flight risk or danger to the community. ${ }^{107}$

DHS faces significant pressure to keep the available detention beds full and has the ability under the applicable regulatory framework to do so, resulting in automatic detention based on bed space rather than individual characteristics. Congress has regularly mandated in recent years that DHS shall maintain the current high number of detention beds, specifically requiring "not less than 34,000 detention beds." 108 The Secretary of DHS has indicated that he does not understand this mandate to require detention of 34,000 individuals but only maintenance of detention space. ${ }^{109}$ However, this interpretation is contested, and the existence of the financed beds pushes in favor of automatic detention anyway. ${ }^{110}$ Rather than making decisions based on the individual characteristics of detainees, DHS will generally detain until the point at which detention space is exhausted, which leads overwhelmingly to detention rather than release in the cases presented for decision. ${ }^{111}$

107. See Sharita Gruberg, No Way Out: Congress' Bed Quota Traps LGBT Immigrants in Detention, CTR. FOR AM. Progress, (May 14, 2015), https://www.americanprogress.org /issues/lgbt/news/2015/05/14/111832/no-way-out-congress-bed-quota-traps-lgbt-immigrants -in-detention/ [https://perma.cc/5CJG-6CNB] (citing FOIA documents establishing that the DHS risk classification assessment tool provided release as an option in $70 \%$ of lesbian, gay, bisexual, and transgender (LGBT) cases, but ICE nonetheless detained LGBT persons in $68 \%$ of those instances presumably because of available bed space).

108. Consolidated Appropriations Act, 2014, Pub. L. 113-76, Div. F., 128 Stat. 5, 251; ReP. John CARTER, DePARTMENT OF HOMELAND SECURITY APPROPRIATIONS Bill, 2015, H.R. REP. No. 113-481, at 50 (2014) (proposing language regarding the requirement of 34,000 beds for 2015); Nick Miroff, Controversial Quota Drives Immigration Detention Boom, WASH. PosT (Oct. 13, 2013), https://www.washingtonpost.com/world/controversial-quota-drives -immigration-detention-boom/2013/10/13/09bb689e-214c-11e3-ad1a-1a919f2ed890_story.html [https://perma.cc/DC6C-GFPG] (noting that appropriations legislation has contained the bed mandate since 2006).

109. United States Department of Homeland Security: Hearing Before the H. Comm. on the Judiciary, 113th Cong. 87 (2014) (testimony of Jeh C. Johnson, Sec'y, U.S. Dep't of Homeland Sec.).

110. See Sen. John Hoeven, Department of Homeland Security Appropriations BILL, 2016, S. REP. No. 114-68, at 53 (2015) (indicating that congressional leaders expect ICE to use all available bed space).

111. See Sarah Childress, Why ICE Released Those 2,000 Immigrant Detainees, PBS: FrontLINE (Mar. 19, 2013) (then-head of ICE, John Morton, reporting that ICE released lowrisk detainees in early 2013 when the numbers of detainees began to exceed the 34,000 beds available); E-mail from Philip T. Miller, Assistant Director for Field Operations, to Field Office Directors and Deputy Field Office Directors (Apr. 14, 2014, 12:10 p.m.) (e-mail obtained through FOIA Response to Andrew Free on file with the Indiana Law Journal) (including message to all ICE field office directors, entitled "Detention Maximization Strategies," seeking suggestions to "more fully utilize the 34,000 beds available nationwide"); E-mail from [REDACTED], to [REDACTED] (Sept. 17, 2013) (hereinafter Sept. 17, 2013 ICE e-mail) (e-mail obtained through FOIA Response to National Immigrant Justice Center on file with the Indiana Law Journal) (directing ICE officers to lower bond amounts imposed after a particular date, across the board, because area detention space "is close to maximum bed space capacity"); E-mail from [REDACTED], Assistant Director for Field Operations to Field Office Directors and Deputy Field Office Directors (Jan. 13, 2012, 03:48 p.m.) (e-mail 
Even absent a congressional mandate to maintain specific levels of detention space, the availability of generous funding for immigration detention spaces would likely continue to drive detention policy and decision making in a manner that presumes detention without regard to established need in individual cases. Neither DHS, which receives the detention budget funding, nor the for-profit corporate entities that receive payments from DHS to manage detention centers have incentives to decrease the available funding for detention slots. ${ }^{112}$ In turn, DHS will generally fill the large number of beds that are funded, absent a framework that requires a firm focus on the necessity of detention in each particular case.

DHS has a further practice of implementing blanket detention policies, which eschew altogether any individualized consideration of need in initial DHS custody determinations for entire groups of migrants. More than once, DHS has insisted on detention of categories of release-eligible migrants in pending immigration court deportation proceedings, without the possibility of release. ${ }^{113}$ In these cases, in its initial

obtained through FOIA Response to National Immigrant Justice Center on file with the Indiana Law Journal) (directing all ICE field office directors to offer suggestions regarding migrants who might be detained to "meet . . congressional mandate of 34,000 beds"); see also HUMAN RIGHTS FIRST, supra note 6, at 31 (quoting deposition of ICE assistant field office director who stated that parole decisions are based on the availability of bed space).

112. See Unlocking Human Dignity, supra note 7, at 185-86 (noting that for-profit entities lobby in their financial self-interest, including for services that government agencies do not need, and that "the privatization of the detention system incentivizes detention growth"). In some cases, the form of government contracts for detention space create even greater incentives for filling all available detention spaces by requiring payment to the for-profit management company of a detention facility for a specific number of beds regardless of whether they are filled. The agency may well consider that it is better to utilize the detention spots that have already been purchased. See generally Det. WATCh NETWORK \& CTR. FOR CONSTITUTIONAL RightS, BANKING ON DETENTION 1 (2015) (providing data on facilities that have "guaranteed minimum" contracts with ICE for detention). In any case, government agencies generally act to use their full budgets to ensure their continuation, particularly where encouraged to do so by the private sector benefitting from the expenditures of the budget dollars. See David A. Fahrenthold, As Congress Fights over the Budget, Agencies Go on Their 'Use It or Lose It' Shopping Sprees, WASH. Post (Sept. 28, 2013), https://www.washingtonpost.com/politics/as -congress-fights-over-the-budget-agencies-go-on-their-use-it-or-lose-it-shopping-sprees/2013 /09/28/b8eef3cc-254c-11e3-b3e9-d97fb087acd6_story.html [https://perma.cc/3VZV-CYL9].

113. See D-J-, 23 I. \& N. Dec. 572, 580-81 (Att'y Gen. 2003), 2003 WL 1953693, at *6 (concluding that Haitian "seagoing migrants" should not be released as a categorical matter); E-mail from Thomas Homan, Executive Associate Director, to Assistant Directors, Deputy Assistant Directors, Field Office Directors, Deputy Field Office Directors, and Assistant Field Office Directors (Feb. 9, 2015, 4:09 PM) (e-mail obtained through FOIA Response to Andrew Free on file with the Indiana Law Journal) (including message sent by ICE Executive Associate Director to field offices stating that all migrants deemed an enforcement priority, including recently arriving asylum seekers, should be detained without opportunity for release except in "compelling and exceptional circumstances"); E-mail from David D. Rivera, New Orleans Field Office Director, to [REDACTED] (Jan. 26, 2015, 3:30 PM (e-mail obtained through FOIA Response to Andrew Free on file with the Indiana Law Journal) (containing message from New Orleans Field Office Director authorizing detention without the possibility for release for entire migrant categories even where DHS risk classification assessment tool recommends release). See generally Taylor, supra note 67 (describing various government 
custody determination, DHS not only makes the decision to detain automatically but orders ongoing detention without the possibility of subsequent release on bond or other conditions. ${ }^{114}$ Such policies were adopted after the $9 / 11$ terrorist attacks in 2001. ${ }^{115}$ Most recently, in the summer of 2014, DHS adopted a policy of detention without the possibility for release on bond for mothers and children arriving from Central America to seek asylum in the United States. ${ }^{116}$ In these cases, DHS explicitly refused for many months to consider individual circumstances relating to flight risk or danger before imposing detention, without the possibility for release on bond or any other conditions, in its initial custody determinations. ${ }^{117}$

The adoption by DHS of an automated risk classification assessment tool, in 2013, has not curbed automatic DHS detention decisions. ${ }^{118}$ In principle, the tool considers characteristics of individual migrants to assist DHS in reaching a custody determination. ${ }^{119}$ However, this tool has not overcome the presumption of detention and the practical considerations that guide DHS custody determinations and so does not ensure that detention is limited to those individual cases where it is needed to address flight risk or danger-to-the-community considerations.

First, the tool is not publicly available, limiting its usefulness in allowing for

policies that led to across-the-board detention of various categories of migrants without opportunity for release, in the wake of the September 11, 2001 terrorist attacks).

114. Of course, the immigration court may review the DHS initial custody determination and order the possibility for release on bond at a later hearing. However, DHS often urges the courts not to intervene when it makes these group-based detention determinations. See D-J-, 23 I. \& N. Dec. 572, 580-81 (U.S. Att'y Gen. 2003), 2003 WL 1953603, at*7 (decision ordering immigration courts and BIA to abide by Attorney General's dictate that members of certain migrant groups should be detained without the opportunity for release on bond); Class Complaint for Injunctive \& Declaratory Relief IIII 47-53, R.I.L-R v. Johnson, 80 F. Supp. 3d 170 (D.D.C. 2015) (No. 15-11) (describing pattern of DHS attorneys arguing against immigration court review of categorical decisions to detain certain asylum-seeking families without opportunity for release).

115. See Taylor, supra note 67 , at $149-50$.

116. Class Complaint for Injunctive \& Declaratory Relief, supra note 114, at IIII 4-5; Guillermo Contreras, Feds Start 'No Bond' Policy on Immigrants at Karnes, SAN ANTONIO EXPRESS-NEws (Aug. 27, 2014, 10:29 PM), http://www.expressnews.com/news/local/article /Feds-start-no-bond-policy-on-immigrants-at-5716884.php [https://perma.cc/7W9Z-6QRA]; U.S. Dep'T of Homeland Security, Redacted Form I-286: Notice of Custody DETERMINATION (completed forms for families detained at the Karnes City Facility on file with the Indiana Law Journal).

117. See Class Complaint for Injunctive \& Declaratory Relief, supra note 114 II 1.

118. DHS does not use the tool in all cases where custody decisions are made. U.S. GAO, Alternatives to Detention, supra note 95, at 8. For example, the tool is not used for individuals in expedited removal after they pass their screening interviews and become eligible for release. Instead, it is used only when they are first detained and are still ineligible for release as the result of an expedited removal order. See OIG REPORT ON ALtERnATIVES TO DETENTION, supra note 92, at 13.

119. Risk Classification Assessment, supra note 92, at 4; Detention Reform Accomplishments, U.S. DeP'T OF Homeland SEC., U.S. IMMIGRATION AND CUSTOMS ENFORCEMENT, https://www.ice.gov/detention-reform\#tab1 [https://perma.cc/GN3H-SQYB]. As described below, the particular factors considered by the tool have not been tested for their relevance or predictive strength. See infra notes 215-17 and accompanying text. 
meaningful individualized determinations by preventing individuals with knowledge of relevant detainee information from providing that information for evaluation. ${ }^{120}$ Second, while the lack of transparency makes it difficult to assess the tool's approach, information provided about the tool suggests that it treats detention as the default position. ${ }^{121}$ As such, it reinforces the automatic resort to detention under the existing legal framework and practice. The tool serves principally to determine detention classifications and to set conditions under which a detainee might subsequently achieve release, usually a bond requirement, rather than analyzing the individual need to detain. ${ }^{122}$ For these reasons, deployment of the tool in the last several years has not led to any notable change in detention rates. ${ }^{123}$

There is one more indicator that individualized determination of the necessity of detention is not the foundation for DHS custody determinations. For migrants detained pending proceedings, DHS does not periodically evaluate the ongoing need to detain. After the initial determination, DHS reconsiders detention only at its discretion based on a request from the detainee or on its own initiative as a result of a new policy or similar change. ${ }^{124} \mathrm{~A}$ system of detention based on individual determinations of necessity would require regular review of the need to detain an individual to ensure that the evaluation of flight risk or danger is still valid. ${ }^{125}$ Yet, such review does not take place.

\section{Lack of Review of Necessity of Detention in Immigration Court Custody Redetermination Hearings}

Immigration court custody redetermination hearings also fail to protect liberty, because they do not serve to limit detention to those individual cases where it is

120. Unlocking Human Dignity, supra note 7, at 171 (noting that ICE has not publicized the criteria used).

121. See OIG Report on Alternatives to Detention, supra note 92, at 25 (showing that the risk classification assessment tool recommended release without a bond requirement less than $1 \%$ of the time in 2013); Risk ClassifiCATION ASSESSMENT, supra note 92, at 3-4 (explaining that the tool helps determine whether an individual should be "detained or released on bond or under other supervision" without any possibility for release without conditions); GAO, Alternatives to DETENTION, supra note 95, at 8 (the tool recommended release, without clarity as to whether a bond was to be required, for only $9 \%$ of migrants to whom the tool was applied in fiscal year 2013). The data regarding releases differs between government reports, making it harder still to assess the functioning of the tool.

122. See Risk Classification Assessment, supra note 92, at 4 (bond considered after determination in favor of detention).

123. See John F. Simanski \& Lesley M. SAPp, OfFice of Immigration Statistics, U.S. DeP'T of Homeland SeC., IMMigRation ENFORCEMENT ACTIONS: 2012, at 1 (2013) (announcing that, for fiscal year 2012, "ICE detained approximately 478,000 foreign nationals, an alltime high"); SIMANSKI, supra note 3, at 1 (announcing that, for fiscal year 2013, "ICE detained nearly 441,000 aliens").

124. 8 C.F.R. $§ 236.1(\mathrm{~d})(2)$ (2016); Risk ClassifiCATION Assessment, supra note 92, at 4 n.6.

125. See, e.g., Parham v. J.R., 442 U.S. 584, 606-07 (1979) (establishing that mental health commitment of a child must be independently reviewed periodically to evaluate continuing need for deprivation of liberty). 
justified by flight risk or danger. The court custody redetermination hearings do not provide prompt and meaningful review of the initial DHS detention decision in order to secure immediate release where necessity is not established.

As to "arriving aliens," and individuals with prior deportation orders, the immigration courts do not offer jurisdiction to redetermine custody status at all. ${ }^{126}$ For entire groups of migrants, then, there is no possibility to seek review of detention. The only recourse after a DHS detention decision is to make a request for release to DHS, the same enforcement entity that made the original decision and serves as custodian.

In those cases where the immigration courts have jurisdiction, it is important to recognize that the opportunity to seek immigration court redetermination of custody does not eliminate the fact of detention, under the initial DHS decision to detain, prior to review. Because the immigration court custody redetermination hearing generally takes place some weeks after detention is ordered, ${ }^{127}$ and only where the detainee requests such reconsideration, the role of the immigration courts in reviewing the initial detention decision is limited. ${ }^{128}$ This system is thus not set up to verify immediately the need to detain or to ensure the accuracy of a DHS decision that detention is necessary, in order to ensure prompt release where detention is not supported. ${ }^{129}$

Immigration courts are also limited in their review of a DHS decision to detain

126. See supra notes 45-46 and accompanying text; see also 8 C.F.R. $§ 1236.1(\mathrm{c})(11)$ (2016) (precluding immigration court custody redetermination hearings where disallowed by 8 C.F.R. $\S 1003.19(\mathrm{~h})$ ) (2016); 8 C.F.R. $§ 1003.19$ (h)(2)(i)(B) (2016) (disallowing immigration court custody redetermination hearings for "arriving" aliens); 8 C.F.R. $§ 1236.1$ (d) (2016) (providing for immigration court custody redetermination hearings only for individuals held in detention under 8 U.S.C. $§ 1226(\mathrm{a})$ ); E-mail from Marlen Piñeiro, Assistant Dir. For Repatriation, \& Philip Miller, Assistant Dir. For Field Operations, to Assistant Dirs., Deputy Assistant Dirs., Field Office Dirs., \& Deputy Field Office Dirs. (July 31, 2014, 2:57 PM) (e-mail obtained through FOIA Response to Andrew Free on file with the Indiana Law Journal) (setting out DHS interpretation that individuals with prior deportation orders who seek refugee protection are held under 8 U.S.C. $\S 1231$ (b) and noting that generally immigration court custody redetermination hearings are unavailable for this group); 8 C.F.R. $\S 1241.14$ (a) (providing for immigration court custody hearings for migrants held under 8 U.S.C. $§ 1231$ in very limited circumstances that do not apply to individuals seeking refugee protection).

127. See supra note 42 and accompanying text; see also 8 C.F.R. $§ 1236.1(d)(1)$ (providing that immigration court custody redetermination hearings are not automatic but rather must be requested by the detained migrant and including no immediacy or other timing requirement for the conduct of such a hearing).

128. $C f$. United States v. Salerno, 481 U.S. 739, 751 (1987) (emphasizing review procedures under the Bail Reform Act as intended to "further the accuracy of [the] determination" that detention is necessary before detention takes place).

129. See Noferi \& Koulish, supra note 13, at 81-83 (noting limits on immigration court review and stating that "DHS both determines and executes initial detention"). The limited role of the immigration court in determining detention or release is further affirmed by a regulatory provision that allows DHS to "stay" the release of a migrant from detention during a DHS appeal of an immigration judge's custody redetermination decision, even where the immigration judge has ordered release on recognizance or parole or upon payment of a bond, if DHS initially ordered detention or imposed a bond of $\$ 10,000$ or higher. 8 C.F.R. $\S 1003.19(\mathrm{i})(2)$. 
by a lack of full independence. Review of detention decisions by an independent authority is a critical safeguard of liberty. ${ }^{130}$ In the immigration context, the immigration courts are within the Department of Justice rather than the Department of Homeland Security and so form part of a separate agency. However, the immigration courts within the Department of Justice and the DHS officers who make initial custody determinations both form part of the same executive branch. The vigor of immigration court review is conditioned by this reality. Where there is an executive policy relating to detention, the immigration courts must consider and generally effectuate that policy. ${ }^{131}$ Even in the absence of such a policy, DHS and the immigration courts coordinate handling of immigration cases. ${ }^{132}$ Given this relationship, the immigration courts do not provide sufficiently independent review of the initial DHS detention decision necessary to assess the individual need for detention and order release as appropriate.

The case law also precludes any true scrutiny by the immigration courts of the threshold detention decision by insisting on broad deference to DHS decisions to detain. ${ }^{133}$ The BIA insists that detainees have no "right" to release and affirms "extremely broad discretion" in initial government decisions to detain or release. ${ }^{134}$ This precedent severely limits the ability of the immigration courts to effectuate an independent review of a detention decision with the possibility of invalidating the detention and ordering immediate release. The original DHS default to detention is thus not meaningfully cabined by immigration court review.

Instead, as with DHS, the immigration courts operate off of a presumption of detention. The case law of the BIA establishes the same standard for immigration judges conducting custody redetermination hearings as applied to the initial decision by DHS. ${ }^{135}$ The BIA has determined that a detained migrant "must establish to the satisfaction of the Immigration Judge" that he or she does not present a danger or flight risk. ${ }^{136}$ This standard employed by the immigration courts considers custody in a posture that treats detention as the default position.

130. See Salerno, 481 U.S. at 750 (referencing importance of "neutral decisionmaker"); UNHCR Detention Guidelines, supra note 63, II 47(iii) (requiring that an asylum seeker be brought before a "judicial or other independent authority" for review of detention); ABA Standards for CRiminal Justice: Pretrial Release, Standards 10-5.9, 10-5.10 (AM. BAR Ass'N, 3d ed. 2007) [hereinafter ABA PRETRIAL RELEASE STANDARDS] (emphasizing role of "judicial officer" in reviewing detention).

131. See D-J-, 23 I. \& N. Dec. 572, 581 (Att'y Gen. 2003), 2003 WL 1953603, at *8 (ruling by Attorney General requiring immigration courts to engage in detention of broad groups in deference to national security considerations brought forward by other agencies in the executive).

132. See, e.g., Memorandum from Print Maggard, Chief Immigration Judge, Exec. Office for Immigration Review, to All Immigration Judges and All Court Administrators 4 (Feb. 3, 2016), https://www.justice.gov/eoir/file/819736/download [https://perma.cc/U5JF-T8MB] (establishing a priority "rocket" docket for certain cases, including cases of unaccompanied and accompanied children, and clarifying that DHS will determine placement on the immigration courts' priority docket).

133. Das, supra note 9 , at 158.

134. Guerra, 24 I. \& N. Dec. 37, 39 (B.I.A. 2006), 2006 WL 3337627, at*3.

135. See id. at 38 .

136. Id. But cf. Rodriguez III, 804 F.3d 1060, 1087 (9th Cir. 2015) (imposing burden of 
The immigration courts are limited to adjudicating a detainee's request for "amelioration of the conditions under which he or she may be released." 137 The immigration courts are thus relegated to considering possible conditions of release, after the detention decision has taken place and has been carried out for some period.

After skipping the inquiry into the decision to detain in the first place, the limited nature of immigration court custody redetermination hearings also makes it unlikely that the court will in fact order outright release even after a period of detention. If the immigration court does not order continued detention, the court will generally set a monetary bond as a condition of release. Once again, the immigration court decision will generally entail detention for at least some additional period, either with the opportunity for subsequent release on bond or without such opportunity. ${ }^{138}$ This decision does not involve scrutiny into the existence of a basis for continued detention based on flight risk or danger.

The immigration court custody redetermination hearings mainly serve, then, to review and regulate financial bonds set as a condition for release after detention begins. ${ }^{139}$ The Immigration Judge Benchbook and Immigration Court Practice Manual, both published by the agency that encompasses the immigration courts, cabin the immigration court decision into one of determining a bond amount as a condition for release. The Immigration Court Practice Manual explicitly limits immigration court review to "the authority to redetermine the amount of bond set by DHS." 140 The Immigration Judge Benchbook similarly emphasizes the decision regarding a bond amount, even insisting that the statute does not allow for release on recognizance. ${ }^{141}$ In practice, many judges refuse to consider the possibility of an order of outright release on recognizance. ${ }^{142}$ Some judges do sparingly order release on recognizance,

proof on government in the 9th Circuit in immigration court custody redeterminations hearings required for specific subset of migrants subject to prolonged detention without such a hearing), cert. granted sub nom. Jennings v. Rodriguez 136 S. Ct. 2489 (2016) (No. 15-1204); Rodriguez II, 715 F.3d 1127, 1135 (9th Cir. 2013).

137. 8 C.F.R. $\S 1236.1$ (d) (2016) (emphasis added).

138. See ACLU of S. CAL., Restoring Due Process 2 (2014) (more than $30 \%$ of migrants assessed bond by the immigration courts, after a federal court order requiring immigration court custody redetermination hearings for individuals previously deemed subject to mandatory detention, were unable to post bond and achieve release).

139. See Ureña, 25 I. \& N. Dec. 140, 141 (B.I.A. 2009), 2009 WL 3983103, at *2 (if migrant is not a danger, then the immigration court should "consider the other factors in the case relevant to determining the amount of bond necessary to ensure the respondent's presence at further proceedings"); Guerra, 24 I. \& N. Dec. at 40, 2006 WL 3337627, at *3 (setting out factors to be considered in custody redetermination hearings in order to determine "the amount of bond that is appropriate").

140. EXEC. OfFICE FOR IMMigration Review, supra note 42, at $\S 9.3(\mathrm{a})$; see also EXEC. OfFice fOR Immigration Review, DeP'T. OF Justice, Fact Sheet: EOIR at a Glance, http://www.justice.gov/eoir/eoir-at-a-glance [https://perma.cc/VB6R-8FDM] (last updated Jan. 8, 2016) (stating that the purpose of "bond redetermination hearings" is "to determine whether to lower or eliminate the amount of a bond set by DHS for an individual detained by DHS").

141. IJ BOND BENCHBOOK, supra note 8, at § I.E.2-3.

142. HUMAN RIGHTS FIRST, supra note 6, at 4 (84\% of attorneys responding to a survey indicated that immigration judges refuse to release individuals without a monetary bond requirement). 
and litigation is underway that would require all immigration courts to consider the possibility for ordering release without payment of a bond. ${ }^{143}$ The guidance documents make evident, though, that the role of the immigration courts in the custody determination process is one of setting bond amounts, which result in continued detention. There is little room for ordering immediate release on an individualized determination that DHS erred in ordering detention where unnecessary or that continued detention is unjustified. On the detention/release binary, detention again prevails for at least some period, extending the period in detention begun by DHS.

The BIA and the federal courts do not provide any more rigorous review of detention on appeal. The BIA reviews the decision of the immigration court under the same standards that limit the scope of the immigration court's inquiry. ${ }^{144}$ Additionally, the BIA often does not decide custody determination appeals until after the final decision on the merits in the deportation proceedings, nullifying the appeal's usefulness for obtaining liberty during the deportation proceedings, where merited. ${ }^{145}$

There is no review by a federal court of the decision to detain, either. ${ }^{146}$ Federal court habeas consideration extends only to the legality of the detention decisionmaking process. ${ }^{147}$ It does not address the merits of the need to detain, based on flight risk or danger, and so does not provide individualized review of detention decisions.

\section{The Overall Inadequacy of the Custody Determination Process as Control on Detention}

As a result of the combination of legal, practical, and policy realities just described, the custody determination process treats detention as the default, rather than the exception required by liberty principles, and does not offer prompt and meaningful review of the need for detention in individual cases. The system serves as an inadequate tool for protection of liberty and control of detention.

Because pretrial detention of release-eligible individuals in deportation proceedings is best described as automatic rather than limited to cases of individualized necessity, the custody determination process essentially treats every migrant in deportation proceedings as posing a threat to security or a significant risk for failure to

143. See Rivera v. Holder, 307 F.R.D. 539, 543-44 (W.D. Wash. 2015) (discussing the request for supplemental briefing, issued in a separate case, on the issue of whether an immigration judge can grant conditional parole or release on recognizance during a custody redetermination hearing).

144. See 8 C.F.R. $§ 1236.1(\mathrm{~d})(3)$ (2016) (providing for BIA review within the section on immigration court review).

145. Charles Roth \& Raia Stoicheva, Nat'l Immigrant Justice Ctr., Order in the COURT: COMmONSENSE SOlutions To IMPROVE EFFICIENCY AND FAIRNESS IN THE IMMIGRATION COURT 26 (2014); see also EOIR StATISTICS YeARbOOK 2015, supra note 5, at $\mathrm{R} 2$ (showing receipts of bond appeals as greater than completions of bond appeals in a given fiscal year).

146. 8 U.S.C. $§ 1226($ e) (2012) (strictly limiting judicial review of custody decisions); see also Prieto-Romero v. Clark, 534 F.3d 1053, 1058 (9th Cir. 2008) ("[D]ecisions granting or denying bond are not subject to judicial review.").

147. See Demore v. Kim, 538 U.S. 510, 516-17 (2003); Kambo v. Poppell, No. SA-07CV-800-XR, 2007 WL 3051601, at *7 (W.D. Tex. Oct. 18, 2007). 
appear at hearings. ${ }^{148}$ This presumption of risk cannot stand, however. ${ }^{149}$ Many migrants have no history that would raise any suggestion of danger and have strong incentives to appear for their hearings in order to pursue opportunities to remain in the United States with stable legal status. ${ }^{150}$ Nor would it be reasonable to suggest that all migrants present a risk because they may not appear for physical removal if ordered removed. ${ }^{151}$ These migrants have not yet had a hearing on deportability or any claims to refugee protection or oher lawful status. It is premature to evaluate flight risk in terms of likelihood of appearance for deportation when many will never be deported but rather will obtain permission to remain permanently in the United

148. E-mail from Thomas Homan, supra note 113 (including message from the ICE Executive Associate Director to field offices indicating that all priority enforcement categories, including recently-arriving asylum seekers, will "generally pose either a danger to persons or property or a flight risk").

149. See, e.g., Zadvydas v. Davis, 533 U.S. 678, 690-92 (2001) (requiring individualized determinations of both flight risk and dangerousness); Patel, 15 I. \& N. Dec. 666, 667 (B.I.A. 1976), 1976 WL 32348, at *1 (finding it impermissible to require a bond "of almost every alien who is held in deportation proceedings"). While every migrant might abscond under some set of circumstances, this reality should not be enough to presume meaningful flight risk preventing release. See SCHNACKE, supra note 93, at 51-52 (noting that "even someone whom we consider the lowest possible risk is still risky nonetheless" but the law allows only reasonable mitigation of that risk). Some case law suggests that release, even on a bond condition, is only appropriate where the migrant presents no risk. Prieto-Romero v. Clark, 534 F.3d at 1067 (in setting bond the immigration judge "necessarily found ... that [the migrant] did not present a flight risk or a danger to the community, and thus merited release") (emphasis in original). This suggestion is misplaced, even under interpretations of immigration law that presume detention. See 8 C.F.R. $\S 236.1$ (c)(8) (2016) (permitting release when "the alien is likely to appear for any future proceeding") (emphasis added); see also Patel, 15 I. \& N. Dec. at 666,1976 WL 32348 , at *1 (allowing detention only where migrant is a "poor bail risk") (emphasis added).

150. See 8 U.S.C. $§ 1229$ b (2012) (providing for cancellation of removal); 8 U.S.C. $§ 1255$ (2012) (providing for adjustment of status); 8 U.S.C. $\$ 1158$ (2012) (providing for asylum); Zadvydas, 533 U.S. at 692 (noting that the potential for removal "bears no relation to a detainee's dangerousness”); U.S. Gov'T ACCOUnTABILITy OfFICE, IMMigRation Detention: Additional Actions Needed To Strengthen Management and Oversight of Facility COSTS AND STANDARDS 8 (2014) (noting that about 44\% of ICE detainees were of a low custody level between 2010 and 2013, with custody levels determined by looking at criminal history, attempts at escape and behavioral history).

151. See Khalifah, 21 I. \& N. Dec. 107, 111 (B.I.A. 1995), 1995 WL 616505, at*4 (finding flight risk based on likelihood of nonappearance for deportation, as well as for hearings, where migrant had strong incentives to avoid deportation because of serious nonpolitical criminal proceedings against him in his home country). The government may have difficulty in apprehending an individual for deportation if not detained at the time of a final deportation order. However, that situation involves failings of the government rather than a risk presented by the migrant justifying detention. The government could redirect resources towards detention and deportation after a final order. See OfFice of the InSPECtor Gen., U.S. DeP'T. OF Justice,

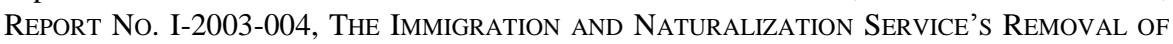
ALIENS ISSUED FINAL ORDERS vi-vii (2003) (recommending measures to ensure removals of nondetained individuals with final deportation orders). 
States. ${ }^{152}$ There can be little doubt, then, that the system sweeps too broadly and sacrifices liberty without adequate justification.

The immigration custody determination process certainly does not parallel the understanding of the individualized review required for pretrial administrative detention in the criminal justice system, even though detention decisions in the two systems should be similarly nonpunitive and justified based on governmental interests relating to flight risk or danger to the community. The different treatment is particularly notable since migrants in deportation proceedings are equated with criminal defendants in other ways and the immigration detention system has imitated some aspects of criminal pretrial detention, as described below. ${ }^{153}$

While imperfect in limiting pretrial detention in practice, in the criminal justice context, a presumption of pretrial release applies rather than a presumption of detention. The government must establish the necessity of detention based on individualized reasons in each case before detaining. Otherwise, it must execute release. ${ }^{154} \mathrm{In}$ addition, the initial decision regarding detention is immediately subject to the consideration of an independent judicial officer to determine whether detention is necessary or to order release, usually within forty-eight hours. ${ }^{155}$ This consideration is

152. See Zadvydas, 533 U.S. at 690 (the justification of preventing flight "is weak or nonexistent where removal seems a remote possibility at best"); EOIR STATISTICS YEARBOOK 2015, supra note 5, at C2 (approximately 30\% of individuals achieved a successful result in their deportation proceedings).

153. See infra Part II.B. This is not to say that the criminal justice model should be followed blindly, as it has its own serious failings, and there are important distinctions between criminal and immigration pretrial detention. See Karen Engle, The Persistence of Neutrality: The Failure of the Religious Accommodation Provision To Redeem Title VII, 76 TEX. L. REV. 317, 431 (1997) (warning of the danger of using comparison to propose legal reform given the tendency to "valorize the body of doctrine that is being deployed as the alternative model," thereby obscuring problems in the model doctrine).

154. ABA PRETRIal Release Standards, supra note 130, at Standard 10-5.1 ("It should be presumed that defendants are entitled to release on personal recognizance . . . . This presumption may be rebutted by evidence that there is a substantial risk of nonappearance or need for additional conditions ....”); VANNOSTRAND, supra note 93, at 8-9 (explaining presumption of release without financial requirements in the federal and most state criminal systems); see also United States v. Salerno, 481 U.S. 739, 748-51 (1987).

155. Cty. of Riverside v. McLaughlin, 500 U.S. 44, 56 (1991) (requiring a hearing regarding detention within forty-eight hours after arrest); Salerno, 481 U.S. at 751 (requiring an adversarial court hearing to decide detention); ABA PRETRIAL RELEASE STANDARDS, supra note 130, at Standards 10-5.9, 10-5.10. The criminal justice protections are sometimes described as applying to decisions to detain without bond. See Salerno, 481 U.S. at 754-55. This formulation does not suggest that immigration detention comports with the criminal pretrial presumption against detention because of the possibility for eventual release on bond. The decision to detain without bond in the criminal context is the decision to detain, to be made after a hearing and only after consideration of all alternatives. See 18 U.S.C. § 3142(c)(2) (2012) (prohibiting bond that results in detention); Salerno, 481 U.S. at 754-55; SCHNACKE, supra note 93, at 9 (the decision in the criminal justice system is intended as "an 'in-or-out,' 'release/detain' decision"). In the immigration context, detention is ordered as a starting point. The possibility for subsequent release on bond or recognizance does not change the character of the detention decision, which should trigger protections against the deprivation of liberty. In practice, a criminal judge may also impose a bond that effectively leads to detention, and 
focused on the threshold question of the necessity of detention before addressing conditions of release that might be imposed if release alone is not appropriate. ${ }^{156}$ Even in those cases where the presence of certain factors may lead to a presumption of the need for detention, for example, in cases involving serious crimes in the federal system, detention may only be imposed in a hearing on the matter of detention before a judicial officer. ${ }^{157}$ The criminal justice system includes robust procedural protections for the detention hearing and decision and the opportunity for full appellate review. ${ }^{158}$

The criminal justice pretrial process contrasts dramatically with the immigration custody determination process for release-eligible individuals in pending deportation proceedings. To understand the contrast fully, one might envision a proceeding in which a police officer orders continued detention of arrestees after apprehension, under a guideline that treats detention as the norm and release the exception, without any mandatory review by a judicial or other fully independent authority. When review of the officer's detention by a separate authority does take place, it is not automatic, immediate, or scrutinizing of the original detention decision. Instead, the review assumes detention is appropriate and principally considers monetary bond conditions on release that ensure continued detention for some period if not throughout the proceedings. The reviewing authority is not judicial or fully independent, and the detainee has no opportunity for meaningful appeal beyond that review. This entire process applies to those arrestees who are likely to present the least risk of flight or danger because they do not fall within a mandatory pretrial detention regime applicable to a broad category of individuals with existing criminal histories.

The immigration custody determination process looks this way when put in criminal justice pretrial detention terms. The comparison between the criminal justice pretrial system and immigration pretrial detention reveals the extent to which the immigration custody determination process fails to safeguard against unjustified pretrial detention of release-eligible individuals pursuant to the constitutional administrative detention paradigm that applies in both systems.

the protections that apply to detention decisions should then adhere there as well. See 18 U.S.C. $\$ 3142(c)(2)$ ("The judicial officer may not impose a financial condition that results in the pretrial detention of the person."); United States v. McConnell, 842 F.2d 105, 109 n.5, 109-10 (5th Cir. 1988) (when bond results in detention, guarantees of full hearing and other protections apply); S. REP. No. 98-225, at 16 (1983) (if bond is the only available assurance against flight and a detainee cannot pay, then the judicial officer should hold a hearing to detain).

156. See Thomas H. Cohen, Office of Justice Programs, U.S. DeP'T. of Justice, NCJ239243, Pretrial Release and Misconduct in Federal District Courts, 2008-2010 3 (2012) (noting that defendants can be released or detained for additional hearings at the initial appearance and establishing that almost $60 \%$ of individuals charged with property and public order crimes were released at their initial appearance while additional individuals charged with these crimes were released at a subsequent pretrial hearing).

157. 18 U.S.C. $§ 3142(f)(2) ;$ Salerno, 481 U.S. at 751; De La Cruz, 20 I. \& N. Dec. 346, 356 (B.I.A. 1991) (Heilman, dissenting), 1991 WL 353522, at $* 8$ (noting that the presumption in the federal criminal context is "severely restricted" in that a judicial officer must find detention necessary by clear and convincing evidence, and contrasting the criminal system with the conclusive use of presumptions in the immigration detention context).

158. See generally Salerno, 481 U.S. at 748-51. 
Nor does the custody determination process provide the type of individualized determination and review of immigration detention that international human rights standards require. International human rights law demands that each decision to detain a migrant must involve a determination regarding necessity with the burden on the government to justify the need in a specific case. ${ }^{159}$ Presumptive or automatic detention is expressly prohibited. ${ }^{160}$ The standards also require "automatic" and "regular" "review of detention" by independent judicial authorities. ${ }^{161}$ The immigration custody determination process does not meet these requirements for adequate protection of liberty. Given the parallels between human rights law and U.S. constitutional principles in this area, the failure of the immigration custody determination process to conform to human rights standards constitutes further evidence of the system's failure to hew to constitutional norms.

At its essence, the custody determination process for release-eligible migrants in immigration court deportation proceedings does not differ greatly in kind from the mandatory detention regime that has been heavily critiqued. ${ }^{162}$ Both provide for automatic detention decisions leading to deprivation of liberty, without a previous individualized determination of the necessity of detention to address flight risk or danger to the community. Neither provide for review of the central decision to detain.

This is not to say that the two categories of detention are identical or even that mandatory detention is not worse in terms of liberty deprivation. The custody determination process for release-eligible individuals at least offers the potential for release during pending immigration court deportation proceedings, after the initial detention decision and some period of detention. Mandatory detention generally does not offer that possibility. However, recognition of the basic nature of detention as the nonindividualized and automatic norm, in both categories, is important. It reveals that the custody determination process for release-eligible individuals does not represent the opposite pole of the detention spectrum from mandatory detention. ${ }^{163}$ As a result, the custody determination process should be viewed as part of the problem

159. IACHR REPORT ON DETENTION, supra note 2, III 35, 37, 39, 134; UNHCR DETENTION GuIDELINES, supra note 63, at III 18-19, 47(v) (providing that decisions to detain must be based on a "detailed and individualised assessment" with the burden on detaining authorities); see also Human Rights Comm., A v. Australia, Communication No. 560/1993, U.N. Doc. CCPR/C/59/D/560/1993, at III 9.2, 9.4 (April 3, 1997) (holding that grounds for detention must be "particular to . . . individual[s]").

160. UNHCR DETENTION GUIDELINES, supra note 63, at II 20 (prohibiting automatic detention as arbitrary); IACHR REPORT ON DETENTION, supra note 2, at III 34, 428 (establishing presumption against detention and disapproving "mandatory detention for broad classes of immigrants"); Vélez Loor v. Panama, Preliminary Objections, Merits, Reparations, and Costs, Inter-Am. Ct. H.R. (ser. C) No. 218, II 118 (Nov. 23, 2010) (finding a violation of liberty in automatic detention of migrants without individualized consideration).

161. UNHCR DETENTION GUIDELINES, supra note 63, at 47(iv) (requiring "regular periodic reviews of the necessity for the continuation of detention"); Human Rights Comm., A v. Australia, Communication No. 560/1993, II 9.4 (requiring periodic review of justification for detention); Velez Loor v. Panama, Inter-Am. Ct. H.R. (ser. C) (No. 218), III 107, 126 (requiring judicial review of immigration detention).

162. See supra notes 11,67 and accompanying text.

163. See, e.g., Kalhan, supra note 10, at 45, 48, 54 (favorably contrasting bond hearings with mandatory detention schemes and recommending greater availability of bond hearings). 
with unjustified liberty deprivation in the context of civil detention for immigration reasons, rather than as the solution to the concerns raised by mandatory detention. Many of the critiques of mandatory detention should be extended to detention of release-eligible individuals and thus to the entire pretrial immigration detention system. In turn, this recognition sounds a note of caution regarding the vulnerability of the limits on nonpunitive administrative detention more generally, including in the pretrial criminal detention context.

Careful inquiry must then take place into the main difference that does exist between migrants subject to mandatory detention and release-eligible migrants - the potential for achieving freedom after a period of detention, during the ongoing immigration court deportation proceedings. The inquiry reveals that release after initial detention is not easily obtained.

\section{B. Selective Borrowing from the Criminal Justice System with Negative Consequences for Liberty}

In determining the possibility for release, usually on condition of payment of a monetary bond, the immigration custody determination process borrows heavily from criminal pretrial systems but ignores the evolution of criminal justice principles towards greater liberty protection. This phenomenon is a variation on the recognized problem of asymmetric incorporation of elements of the criminal justice system into the immigration setting without adoption of the procedural guarantees available to criminal defendants. ${ }^{164}$ Here, the immigration system has adopted from criminal justice pretrial detention models selectively, incorporating certain aspects of criminal pretrial detention without studying the lessons learned in the criminal context.

As a result, from a liberty perspective, immigration detention has taken much of the bad but not the good from the criminal pretrial justice system. The selective borrowing has led to the buildup of a system under which migrants regularly remain detained for lengthy periods after the original detention decision and often throughout their immigration court deportation proceedings. Freedom continues to be out of reach even where it has not been established that detention is necessary to prevent flight or danger to the community.

\section{Emphasis on Monetary Bonds}

With detention as the automatic starting point, the immigration custody determination process focuses at all stages on setting monetary bond amounts as a condition of release. It is for this reason that the immigration custody determination process is often referred to under the moniker of "bond hearings" or "seeking bond."

The emphasis on monetary bond severely limits the ability for release, as described above. Despite its impact on liberty, though, bond remains the central

164. Stephen H. Legomsky, The New Path of Immigration Law: Asymmetric Incorporation of Criminal Justice Norms, 64 WASH. \& LEE L. REV. 469, 472-73 (2007); see generally Juliet Stumpf, The Crimmigration Crisis: Immigrants, Crime, and Sovereign Power, 56 AM. U. L. REV. 367 (2006) (laying out theory that only the harshest and most exclusionary portions of criminal law make their way into the immigration law framework). 
consideration. As noted previously, release on recognizance is rare. ${ }^{165}$ In addition, conditions for release other than monetary bond are not systematically considered.

In its initial custody determination, DHS may consider release on the condition of enrollment in a formal alternative-to-detention program. ${ }^{166}$ However, these programs consist mostly of electronic ankle monitoring and other reporting requirements administered by private contractors. ${ }^{167}$ The programs thus raise their own liberty questions and also have geographical and capacity limitations. ${ }^{168}$ The effectiveness of these programs has not been established. ${ }^{169}$

There is no system for DHS to assess the needs of a migrant, such as lack of housing or legal counsel, and to offer assistance that would address those specific concerns that make it less likely that a migrant will appear for hearings without detention. ${ }^{170}$ Use of alternative conditions that would allow for immediate release, in place of a bond requirement, is therefore uncommon. ${ }^{171}$

165. See supra notes 26-28, 95 and accompanying text.

166. Risk ClASSIFICATION ASSESSMENT, supra note 92, at 4.

167. See GAO, Alternatives to Detention, supra note 95, at 9-10; The GEO Group Awarded Contract by U.S. Immigration and Customs Enforcement for the Continued Provision of Services Under Intensive Supervision and Appearance Program, BUS. WIRE (Sept. 10, 2014, 8:36 AM), http://www.businesswire.com/news/home/20140910005643/en /GEO-Group-Awarded-Contract-U.S.-Immigration-Customs [https://perma.cc/VKW4-9CZ2] (noting that private corrections company GEO has secured the contract for the supervision program that forms the "core component of the Department of Homeland Security's Alternatives to Detention program").

168. See 2015 ICE Budget ReQuest, supra note 105, at 60-63 (pages 1308-11 of full document) (noting limit on availability of formal alternatives-to-detention spots and difficulties in expansion because of resource constraints); LESLIE E. VÉLEZ \& MEGAN BREMER, LUTHERAN IMMIGRATION AND REFUGEE SERVS., UNLOCKING LIBERTY: A WAY FORWARD FOR U.S. IMMigRATION DETENTION POLICY 31-32 (2011) (reporting resource constraints on institutional alternatives-to-detention programs, such as the fact that certain programs exist only within a certain radius from a limited number of designated ICE offices).

169. See GAO, Alternatives to Detention, supra note 95, at 31-36; OIG RePORT on Alternatives to Detention, supra note 92, at 8.

170. See Megan Bremer, Kimberly Haynes, Nicholas Kang, Michael D. Lynch \& Kerri Socha, New Models for Alternatives to Detention in the US, ForCED MigRATIOn Rev., Sept. 2013, at 50-51 (urging use of such evaluation and support programs). But cf. U.S.

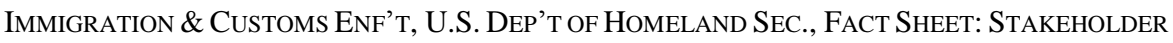
REFERRALS TO THE ICE/ERO FAMILY CASE MANAGEMENT PROGRAM (2016), http://www.ilw.com /immigrationdaily/news/2016,0111-ICE.pdf [https://perma.cc/U8BR-5YF3] (announcing a small, geographically-limited program for case management services run by a for-profit company).

171. See GAO, Alternatives to Detention, supra note 95, at 8 (showing that, in 2013, migrants were released pretrial through alternatives-to-detention programs with almost half the frequency that they were released after payment of a monetary bond). DHS has recently dramatically increased the use of electronic ankle monitoring upon release of women and children who were apprehended together at the border. See E.C. Gogolak, Ankle Monitors Weigh on Immigrant Mothers Released from Detention, N.Y. TIMES (Nov. 15, 2015), http://www.nytimes.com/2015/11/16/nyregion/ankle-monitors-weigh-on-immigrant-mothers -released-from-detention.html?_r=1 [https://perma.cc/75E3-YFW7]. However, this trend should not be seen as a diminution in the use of detention and monetary bond. The practice 
Similarly, in custody redetermination hearings in immigration court, the judges do not consider possibilities for release other than release on bond, or on recognizance or conditional parole in rare cases. The applicable regulations do not give the immigration courts clear authority to order release from detention upon conditions other than bond, such as electronic monitoring or registration for services. ${ }^{172}$ In any case, structural arrangements do not exist that would allow the immigration courts to condition release on enrollment in a formal alternative-to-detention program. DHS controls entry into alternative-to-detention supervision and other programs. ${ }^{173}$ The immigration courts cannot usually require ICE to make a particular program available to a migrant as a condition for release from detention. Bonds thus remain the focal point of the immigration court custody redetermination hearings.

The concept of pretrial detention with bond as the primary condition for potential release is patterned on the tradition of the criminal justice system. ${ }^{174}$ However, the immigration system has not followed more recent developments in the criminal pretrial justice system that move away from the use of monetary bond. The particular emphasis on monetary bond in the immigration detention context has taken place relatively recently, after monetary bonds had already been discredited in the criminal pretrial justice system. ${ }^{175}$

has largely applied to a specific group of women and children. Also, given that the electronic monitors are not imposed after any individual finding of flight risk or danger that they are calibrated to ameliorate, the monitors should be seen as an alternative form of deprivation of liberty rather than a mechanism for release on conditions that address established flight risk or danger through means other than requirement of a monetary bond.

172. See 8 C.F.R. $§ 1236.1$ (d) (2016) (allowing immigration court review only to decide detention, release, or release on bond); $c f$. Rodriguez II, 715 F.3d 1127, 1131 (9th Cir. 2013) (ordering immigration courts to order placement in alternatives-to-detention programs where appropriate); ACLU OF S. CAL., RESTORING DUE PROCESS, supra note 138, at 4 (explaining that for a specific set of cases in which a federal court ordered the immigration courts to consider alternatives to detention, release on alternatives-to-detention alone (without payment of bond) occurred in fewer than $1 \%$ of cases). Immigration courts can generally review conditions imposed by DHS, such as imposition of an electronic monitoring device, but cannot readily impose conditions on their own. Garcia-Garcia, 25 I. \& N. Dec. 93, 96, 98 (B.I.A. 2009), 2009 WL 3309140, at *3, 5 .

173. See GAO, Alternatives to Detention, supra note 95, at 8-9, 9 n.21 (noting that ICE manages alternatives-to-detention programs and places migrants into the programs while the immigration courts are only authorized to place migrants into the programs in "limited circumstances relating to ongoing class action litigation"); VÉLEZ \& BREMER, supra note 168, at 29-34 (describing the functioning of alternatives-to-detention programs and the manner in which DHS refers migrants into the programs).

174. See Wong Wing v. United States, 163 U.S. 228, 235 (1896) (justifying detention for immigration purposes on the grounds that "[d]etention is a usual feature of every case of arrest on a criminal charge"); SCHNACKE, supra note 14, at 29 (dating the widespread use of money bond in criminal pretrial proceedings to 100 years ago); César Cuauhtémoc García Hernández, Immigration Detention as Punishment, 61 UCLA L. REV. 1346, 1372-79 (2014) (tracing expansion of immigration detention to increasing connection between immigration and criminal law); Legomsky, supra note 164, at 489-94 (treating expanded preventive detention in the immigration context as incorporation of criminal norms).

175. Compare Drysdale, 20 I. \&. N Dec. 815, 817 (B.I.A. 1994), 1994 WL 232084, at *2 ("Once it is determined that an alien does not present a danger to the community or any bail 
The focus on monetary bonds as the central issue in the custody determination process, and the only real mechanism for securing release after a detention decision, demonstrates the error of adopting the criminal justice model without due attention to criminal justice developments. In the criminal justice context in which monetary bonds arose, there has been significant research that demonstrates the inefficiency of using financial bonds to prevent flight risk or danger as well as the inherent unfairness of relying on monetary guarantees as a primary condition for release from detention.

In the criminal justice context, studies over several decades have shown that imposition of a monetary bond is not an effective way to minimize the risk of flight or danger to the community. Research and analysis establishes that monetary bond is not effective at preventing danger to the community by deterring criminal activity. ${ }^{176}$ As to addressing flight risk, the research has not shown that monetary requirements are effective, because it is not at all clear that money motivates appearance in court. ${ }^{177}$ In fact, even short periods of detention, such as those that may result from the need to gather a bond sum before securing release, have been shown to have negative effects on compliance with ongoing proceedings after release. ${ }^{178}$ In addition, bond is a very dull instrument for managing flight risk when compared to tools that allow decision makers to target nonmonetary conditions of release towards specific risk factors presented by individuals who may evade proceedings if released without conditions. ${ }^{179}$

In addition, the criminal pretrial justice research confirms that a system revolving around monetary bonds results in greater likelihood of detention for indigent

risk, then no bond should be required."), and Sanders, supra note 12, at 143, 146 (finding in 1993 that release without a bond requirement was allowed in almost $70 \%$ of cases in a sample, while bond was required in fewer than $25 \%$ of cases in the sample), and GAO, ALTERNATIVES TO DETENTION, supra note 95, at 8 (noting that release after payment of a bond was the most common mechanism for leaving ICE detention in 2013), with PRETRIAL RelEASE AND MisCONDUCT, supra note 156, at 2 (noting that financial bonds were used almost exclusively in the federal criminal system at one time but only up until 1966), and SCHNACKE, supra note 14, at 36-40 (noting efforts to diminish the role of monetary bond dating back to the period between the 1920s and 1960s and noting that intensive reform of bond practices in the pretrial criminal justice context dates to the 1990s).

176. See generally Curtis E.A. Karnow, Setting Bail for Public Safety, 13 BERKELEY J. CRIM. L. 1 (2008).

177. See SCHNACKE, supra note 14, at 13; SCHNACKE, supra note 93, at 32 ("[E]xpecting money to effectively mitigate risk . . . is historically unfounded.").

178. SCHNACKE, supra note 14, at 16-17 (noting that "even small amounts of pre-trial detention - perhaps even the few days necessary to secure funds to pay a cash bond ...- - have negative effects" and create greater risk of failure to appear or danger); SCHNACKE, supra note 93, at 49 (in the criminal pretrial context, even "short periods" of detention correlate with negative outcomes in terms of pretrial compliance and outcomes on the merits).

179. See Justice Policy InST., supra note 31, at 4, 21 (explaining that monetary bail has not been empirically shown to correlate with appearance rates and is an inefficient tool); Samuel R. Wiseman, Pretrial Detention and the Right To Be Monitored, 123 YALE L.J. 1344, 1347-49 (2014) (noting inefficiency of monetary bond system in securing appearance in the criminal justice context and advancements in other means of addressing flight risk). See generally RonAld GoldFARB, RANSOM: A CRITIQUe OF THE AMERICAN BAIL SYSTEM (1965); SCHNACKE, supra note 93. 
individuals and less detention for the affluent, regardless of actual flight risk or danger to the community. ${ }^{180}$ This problematic effect of reliance on monetary bonds is magnified because detention tends to correlate with negative results in final outcomes (higher rates of conviction and longer sentences, in the criminal context). ${ }^{181}$ Perhaps even more worrisome, the evidence suggests that financiallybased pretrial detention systems have a disparate negative impact on minorities. ${ }^{182}$

As a result, by the $1960 \mathrm{~s}$, there was broad acknowledgment by experts that the criminal justice system needed to move away from financial bonds. ${ }^{183} \mathrm{~A}$ presumption of liberty was reaffirmed and the focus shifted to rigorous pretrial screening programs designed to identify for attention those individuals presenting a true flight risk or danger. ${ }^{184}$ The screening is intended to allow for release wherever possible, even

180. Thomas H. Cohen \& Brian A. Reaves, Bureau of Justice Statistics, U.S. Dep'T of Justice, NCJ 214994, Pretrial Release of Felony Defendants in State Courts 1 (2007) (finding many criminal defendants were detained pretrial because of inability to meet the financial conditions required for release); JustiCE POLICY InST., supra note 31, at 4, 14 ("those too poor to pay a money bail remain in jail regardless of their risk level"); Partnership for Cmty. Excellence, Cal. Forward, Pretrial Detention \& Community SuPERVISION: Best PRACTICES AND RESOURCES FOR CALIFORNiA COUNTIES 12 (Sharon Aungst ed., 2012) [hereinafter CALIFORNIA BEST PRACTICES] ("[T] here is no research to support . . . a tie [between bond and flight risk] since the ability to pay a bond is more closely linked to economic circumstances than to risk."); Arthur W. PePin, Conference of State Court ADM'RS, EVIDENCE-BASEd PRETRIAL RELEASE 4 (2013) ("Many of those incarcerated pretrial do not present a substantial risk of failure to appear or a threat to public safety, but do lack the financial means to be released."); John Clark, The Impact of Money Bail on Jail Bed Usage, AM. JAILS, July/Aug. 2010, at 47, 50 (citing several commentaries concluding that the use of monetary bond does not serve legitimate goals of protecting public safety and instead ensures that the poorest defendants will remain in detention while those with resources will be released); Wiseman, supra note 179, at 1359-61 (describing "wealth discrimination" resulting from the use of monetary conditions on release and also analyzing the ineffectiveness of monetary bonds in incentivizing appearance in court).

181. See John S. GoldKamp, Two Classes of Accused: A Study of Bail and Detention in American Justice (1979); Justice Policy Inst., supra note 31, at 13; PePin, supra note 180 , at 5 .

182. See Justice Policy InST., supra note 31, at 15-16; PePIN, supra note 180, at 4-5.

183. See Bail Reform Act of 1966, Pub. L. No. 89-465, 80 Stat. 214 (codified as amended at 18 U.S.C. $\S \S 3146-3152$ ) (creating a presumption of pretrial release and making financial conditions a last resort in terms of conditions to be imposed); ABA PRETRIAL RELEASE STANDARDS, supra note 130, at Standard 10.5.3 (providing that financial conditions are to be imposed only when no other less restrictive condition of release will ensure appearance at proceedings). The ABA Pretrial Release Standards that lay out much of this framework are not legally binding but enjoy great respect and are regularly cited by policymakers and courts as laying out a model for decision making. See, e.g., SCHNACKE, supra note 14, at 96 (citing the standards); PEPIN, supra note 180, at 10 (same).

184. E.g., ABA Pretrial Release Standards, supra note 130, at Standard 10-1.5 (encouraging development of drug, mental health, and other alternatives to detention as well as new approaches to monitoring defendants); $i d$. at Standard 10-1.10 (establishing importance of development of a pretrial services agency to conduct risk assessments and provide services and monitoring to individuals on pretrial release); $i d$. at Standard 10-4.2 (setting out importance of assessing objective criteria in determining flight risk or danger and considering 
where some risk of flight or danger exists, through development of a range of alternatives to detention that address any risk factors arising in individual cases without conditioning release on payment of a monetary bond. These alternatives include educational and other support components as well as monitoring elements. ${ }^{185}$ The system does foresee detention in some instances, as a last resort to be used upon a determination of high risk that cannot be addressed other than by detention. ${ }^{186}$ However, under this framework, detention should not result by default from a monetary bond requirement. ${ }^{187}$

To be clear, not all criminal jurisdictions have embraced this change in focus away from pretrial detention with a monetary bond system, and money bonds still play a problematic role in the criminal justice system. ${ }^{188}$ But there is certainly movement away from the use of monetary bond. Courts, policymakers, and advocates enjoy broad awareness of the desirability of aligning the system with the available research establishing the benefits of such change. ${ }^{189}$ For example, the District of Columbia has virtually eliminated the use of money bond as a condition of release from pretrial criminal detention. Instead, the District of Columbia has supported a strong Pretrial Services Agency that engages in active supervision of released defendants and provides a range of support services to them. ${ }^{190}$ In doing so, it has documented remarkably low absconding rates and rates of new violent crimes by those released. ${ }^{191}$

possibility for enrollment in release programs); JUSTICE POLICY INST., supra note 31, at 32-34; PEPIN, supra note 180, at 2, 6-9.

185. Justice Policy Inst., supra note 31, at 32-34; Marie VanNostrand \& Gena Keebler, Pretrial Risk Assessment in the Federal Court, 73 Fed. Prob. 3, 7 (2009); CALIFORNiA Best PRACTICES, supra note 180, at 9; Wiseman, supra note 179, at 1363.

186. ABA PRETRIAl Release StANDARDS, supra note 130, at Standard 10-1.6.

187. Id. at Standard 10-5.3.

188. See, e.g., Laura And John ARnold Found., Developing a National Model for PRETRIAL RISK ASSESSMENT 2 (2013) (finding that less than $10 \%$ of U.S. jurisdictions use datadriven pretrial risk assessments, and those jurisdictions that do so have limited pretrial detention at significant cost savings); SCHNACKE, supra note 14, at 10 (laying out "negative outcomes" of the monetary bail system, including pretrial detention at a rate that is "three times the world average"); Wiseman, supra note 179, at 1349 (noting that reform diminishing the importance of monetary bonds has struggled against "the will of the commercial bail industry").

189. See Nat'l Ass'n of Pretrial Servs. Agencies, The Truth About Commercial BAIL BONDING IN AMERICA 4 (2009) (noting that some states have prohibited commercial bond systems); PEPIN, supra note 180, at 10-11 (identifying jurisdictions that have made changes while acknowledging resistance to change, particularly given commercial interests in the current system); SCHNACKE, supra note 14, at 80-82 (noting trend towards changes in laws and policies and listing organizations that have advocated for improvements in the process for determining pretrial custody).

190. See Schnacke, supra note 93, at 60; see also Pretrial Services Agency of D.C., http://www.psa.gov/ [https://perma.cc/S5TP-BPG4].

191. SCHNACKE, supra note 93 , at $57 \&$ n.138 (commenting on the "virtually moneyless administration of bail performed each day in the District of Columbia" and citing statistics that show that $89 \%$ of released defendants appeared for all court dates and only $1 \%$ committed a violent crime). 
However, it is as if news of these developments has not even reached the immigration detention system, although many of the same problems with monetary bond identified in the criminal pretrial system apply in immigration cases. As with criminal pretrial detention, there is a similar likelihood that indigent migrants will remain detained for most or all of their immigration court deportation proceedings, because of inability to pay a financial bond, without regard for their actual flight risk or danger to the community. ${ }^{192}$ The racial impacts of the reliance on money bonds have not been studied in the immigration context but may well be significant. ${ }^{193}$

In addition, detention during immigration proceedings has a strong negative impact on final outcomes in immigration proceedings. Detained individuals are much less likely to succeed in their immigration court cases and avoid deportation than are those not in detention. ${ }^{194}$ That impact is likely even greater in the immigration context than in the criminal context, because migrants are not entitled to appointed counsel. Migrants face even greater difficulties in obtaining legal representation if detained, and representation is a key factor in achieving successful outcomes in the underlying immigration court case. ${ }^{195}$ Perhaps even worse, some migrants give up viable claims to immigration status and relief from deportation rather than remain in

192. HumAn Rights FIRST, supra note 6 (including examples of individuals who remained in detention throughout immigration court deportation proceedings because of inability to pay bond); INSECURE COMMUNITIES, supra note 95, at 11 (explaining that 55\% of migrants for whom a bond is set do not obtain release because of inability to pay the bond amount); Eagly \& Shafer, supra note 6, at 69 n.220 (noting that many immigrants are not able to afford high bonds).

193. See Sanders, supra note 12, at 158 (reviewing small sample custody determination set from 1993 and concluding tentatively that "Anglos did tend to receive lower bonds than Hispanics, and Blacks"). Individuals placed in deportation proceedings are disproportionately Latin American, so bond practices have a greater negative impact on these minorities, particularly because they also tend to have lower income levels. See Columbia Law Sch. Human Rights Inst. \& Ne. Univ. Sch. of Law Program on Human Rights and the Glob. Econ., Equal Access to Justice: Ensuring Meaningful Access to Counsel in Civil Cases, INCLUDING IMMIGRATION PROCEEDINGS 5-6 (2014) (finding that "Latin American immigrants are disproportionately targeted for removal proceedings" and are "more likely to be poor"); Adam B. Cox \& Thomas J. Miles, Policing Immigration, 80 U. CHI. L. REV. 87, 112-115 (2013) (finding that the "Secure Communities" immigration enforcement program focused on heavily Hispanic communities).

194. Peter L. Markowitz, Jojo Annobil, Stacy Caplow, Peter v.Z. Cobb, Nancy Morawetz, Oren Root, Claudia Slovinsky, Zhifen Cheng, \& Lindsay C. Nash, Accessing Justice: The Availability and Adequacy of Counsel in Removal Proceedings, 33 CARDOzO L. REV. 357 , 363-64 (2011) (finding that only 3\% of unrepresented detained individuals have a successful outcome); see also Representation Is Key in Immigration Proceedings Involving Women with Children, TRAC IMMIGRATION (Feb. 18, 2015), http://trac.syr.edu/immigration/reports/377 [https://perma.cc/D26A-RNHV] (establishing difficulty of detained families in obtaining representation and showing that "a critical factor influencing outcome is whether the immigrant is represented").

195. Eagly \& Shafer, supra note 6, at 32 (finding that detained migrants are five times less likely to obtain counsel than nondetained individuals); Andrew I. Schoenholtz \& Hamutal Bernstein, Improving Immigration Adjudications Through Competent Counsel, 21 GEO. J. LEGAL ETHICS 55, 55-56 (2008) (pointing out that detainees are more limited in obtaining representation, which is the "single most important non-merit factor" determining outcomes). 
detention to await the outcome of immigration court proceedings. ${ }^{196}$ These decisions result in deportation of individuals who may face danger or other significant harms in their home countries, as a result of detention rather than the legal standards that should determine eligibility to remain in the United States.

Furthermore, there has been no research establishing that monetary bonds are effective in addressing risks of flight or danger presented by migrants in immigration court deportation proceedings. ${ }^{197}$ Many migrants do not even understand that bond money is intended to assure appearance and will be returned if there is compliance with that obligation. ${ }^{198}$ Bond is thus unlikely to serve as an incentive. The arbitrary nature of the immigration bond-setting process, as described below, makes it particularly unsuited to incentivizing behavior to address any actual risk of flight or danger. ${ }^{199}$

As in the criminal justice system, the use of bond may actually create greater risk of nonappearance. Detention for even some period, often while waiting to pay or seek a reduction in bond, appears to be correlated with somewhat lower appearance rates after release. ${ }^{200}$

The immigration system has nonetheless adhered to the focus on monetary bonds despite the lessons learned from the criminal justice system about the inadvisability of allowing money to dictate pretrial detention. As a result, all too often the initial decision to detain is followed by lengthy additional detention, because the imposition of bond impedes release without regard to flight risk or danger. Liberty is thus compromised.

196. See Motion to Withdraw Appeal, Salinas-Mendoza, No. A202-079-353 (B.I.A. June 14, 2016) (on file with the Indiana Law Journal) (explaining decision to withdraw BIA appeal, despite fear of return to home country, because of detention); HUMAN RIGHTS FIRST, supra note 6, at 20-21 (providing example of asylum seekers who withdrew their claims in order to achieve release).

197. See GAO, Alternatives to Detention, supra note 95, at 33, 33 n.66 (acknowledging that ICE does not maintain full data regarding migrants released after paying bond, much less particular bond amounts, which might allow analysis of effectiveness in improving appearance rates or other compliance); Das, supra note 9, at 152 (noting that available data does not establish nonappearance rates as a function of bond release characteristics).

198. See Emily Ryo \& Caitlin Patler, Bonding Out: Judicial Decision-Making in Immigration Bond Hearings 28 (Oct. 5, 2014) (unpublished manuscript on file with Indiana Law Journal) (noting that unrepresented migrants expressed confusion about the purpose of custody redetermination hearings); Florence ImMigrant AND RefugEe Rights Project, All ABOut Bonds 2 (2011), http://archive.vera.org/sites/default/files/resources/downloads 15\%20-\%20Bond\%20Packet_English_LOP\%20CD.pdf [https://perma.cc/C42E-K8UJ] (providing explanation to immigration detainees that a bond "is not a fine" and will be repaid if the detainee appears for hearings after release, in reflection of the common confusion among immigration detainees about bonds).

199. See Part II.B.2.b.

200. EOIR StATISTICS YEARBOOK 2015, supra note 5, at P2-P3 (explaining that for fiscal years 2011-2014, in absentia decision rates as a percentage of total decisions for individuals detained and then released are higher than those never detained). 


\section{The Problematic Use of Criminal Justice Pretrial Considerations}

Selective adoption of elements from the criminal pretrial context with problematic results extends further in the immigration custody determination process, however. In setting bond, the immigration authorities use factors copied from pretrial risk determination in the criminal justice system, again without adoption of important considerations that have developed alongside these factors in the criminal context. ${ }^{201}$

The degree of adoption of criminal elements into the immigration system is evident from Table 1 below. The factors used to set bond in immigration custody proceedings are shown in the first column. ${ }^{202}$ Set out alongside these factors, in the second and third columns, are the factors considered in the pretrial criminal justice setting to assign a risk level for the purpose of determining whether release is possible or whether pretrial detention is necessary. ${ }^{203}$ Where release is possible, these factors may also be used for the purpose of imposing conditions to control specific identified risk concerns, after release. The factors in all three columns largely mirror one another.

201. E.g., San Martin, 15 I. \& N. Dec. 167, 168 (B.I.A. 1974), 1974 WL 30025 *2 (explicitly incorporating factors from the pretrial justice system, specifically the Bail Reform Act, into the immigration custody determination process).

202. See Guerra, 24 I. \& N. Dec. 37, 40 (B.I.A. 2006), 2006 WL $3337627 * 3$ (setting out the factors). The specific factors considered by DHS in assessing bond at the initial custody determination stage, through use of the risk classification assessment tool or otherwise, are not readily available but appear to track the BIA factors. See Risk Classification ASSESSMENT, supra note 92, at 4 (listing factors for ICE to consider in determining custody); Noferi \& Koulish, supra note 13, at 59-68 (identifying factors considered by the risk classification assessment tool which mirror factors identified in Guerra, 24 I. \& N. Dec. 37).

203. See 18 U.S.C. $§ 3142$ (g) (2012) (listing factors for consideration in deciding pretrial release or detention in the federal criminal justice system); ABA PRETRIAL ReleASE STANDARDS, supra note 130, at Standard 10-5.1 (listing standards for determining when release is possible and for conditions on release that address risk factors); see also N.Y. CRIM. PROC. LAW § 510.30(2)(a) (McKinney Supp. 2016) (setting out similar factors for New York pretrial system). 
Table 1. Adoption of Criminal Elements into Immigration System

\begin{tabular}{|c|c|c|}
\hline $\begin{array}{l}\text { Matter of Guerra (BIA 2006); }{ }^{204} \\
\text { Matter of X-K-(BIA 2005); }{ }^{205} \\
\text { Matter of Andrade (BIA 1987) }{ }^{206}\end{array}$ & $\begin{array}{l}\text { Bail Reform Act }(1984) ;{ }^{207} \\
\text { United States v. Salerno, } \\
481 \text { U.S. } 739(1987)^{208}\end{array}$ & $\begin{array}{l}\text { ABA Pretrial Release } \\
\text { Standards }(2002)^{209}\end{array}$ \\
\hline $\begin{array}{l}\text { Length of residence in the } \\
\text { United States }\end{array}$ & $\begin{array}{l}\text { Length of residence in } \\
\text { community }\end{array}$ & $\begin{array}{l}\text { Length of residence in } \\
\text { community }\end{array}$ \\
\hline $\begin{array}{l}\text { Employment history in the } \\
\text { United States, including length } \\
\text { and stability }\end{array}$ & Employment & $\begin{array}{l}\text { Employment status and } \\
\text { history }\end{array}$ \\
\hline $\begin{array}{l}\text { Family ties in the United States } \\
\text { (and whether ties may lead to } \\
\text { status) }\end{array}$ & $\begin{array}{l}\text { Family ties; community } \\
\text { ties }\end{array}$ & $\begin{array}{l}\text { Family ties; } \\
\text { community ties }\end{array}$ \\
\hline Record of appearance in court & $\begin{array}{l}\text { Record concerning } \\
\text { appearance at court } \\
\text { proceedings }\end{array}$ & $\begin{array}{l}\text { Record concerning } \\
\text { appearance at court } \\
\text { proceedings }\end{array}$ \\
\hline $\begin{array}{l}\text { Criminal record, including } \\
\text { extensiveness, recency, and } \\
\text { seriousness }\end{array}$ & $\begin{array}{l}\text { Nature and circumstances } \\
\text { of offense charged; } \\
\text { whether at time of arrest } \\
\text { on probation or parole }\end{array}$ & $\begin{array}{l}\text { Nature and } \\
\text { circumstances of } \\
\text { offense charged; } \\
\text { criminal history; } \\
\text { whether at time of } \\
\text { arrest on probation or } \\
\text { parole }\end{array}$ \\
\hline $\begin{array}{l}\text { History of immigration } \\
\text { violations }\end{array}$ & Past conduct & Past conduct \\
\hline $\begin{array}{l}\text { Attempts to flee prosecution or } \\
\text { otherwise escape authorities }\end{array}$ & $\begin{array}{l}\text { Record concerning } \\
\text { appearance at court } \\
\text { proceedings }\end{array}$ & $\begin{array}{l}\text { Record of appearance } \\
\text { at court proceedings }\end{array}$ \\
\hline $\begin{array}{l}\text { Manner of entry into the United } \\
\text { States }\end{array}$ & - & - \\
\hline Fixed address & - & - \\
\hline $\begin{array}{l}\text { Possibility of success on the } \\
\text { merits of application for relief }\end{array}$ & $\begin{array}{l}\text { Weight of evidence } \\
\text { against the person }\end{array}$ & Weight of the evidence \\
\hline
\end{tabular}

204. Guerra, 24 I. \& N. Dec. 37, 40, 2006 WL 3337627, at*3.

205. X-K-, 23 I. \& N. Dec. 731 (B.I.A. 2005), 2005 WL 1104422.

206. Andrade, 19 I. \& N. Dec. 488, 489-90 (B.I.A. 1987), 1987 WL 108952, at*2.

207. Bail Reform Act of 1984, ch. I, sec. 203, § 3142(g), 98 Stat. 1976, 1980 (codified as amended at 18 U.S.C. $§ 3142$ ).

208. United States v. Salerno, 481 U.S. 739 (1987).

209. ABA PREtrial Release StANDARDS, supra note 130, at Standards 10-5.1, 10-5.8. 


\begin{tabular}{|c|c|c|}
\hline $\begin{array}{l}\text { Matter of Guerra (BIA 2006); }{ }^{204} \\
\text { Matter of X-K- (BIA 2005);205 } \\
\text { Matter of Andrade (BIA 1987) })^{206}\end{array}$ & $\begin{array}{l}\text { Bail Reform Act (1984); }{ }^{207} \\
\text { United States v. Salerno, } \\
481 \text { U.S. } 739(1987)^{208}\end{array}$ & $\begin{array}{l}\text { ABA Pretrial Release } \\
\text { Standards }(2002)^{209}\end{array}$ \\
\hline Character & $\begin{array}{l}\text { Person's character, } \\
\text { physical and mental } \\
\text { condition; history relating } \\
\text { to drug or alcohol abuse }\end{array}$ & $\begin{array}{l}\text { Person's character, } \\
\text { physical and mental } \\
\text { condition; history } \\
\text { relating to drug or } \\
\text { alcohol abuse }\end{array}$ \\
\hline - & Financial resources & Financial resources \\
\hline $\begin{array}{l}\text { Migrants who present a danger } \\
\text { to persons or property should not } \\
\text { be released }\end{array}$ & $\begin{array}{l}\text { Nature and seriousness of } \\
\text { the danger posed by the } \\
\text { person's release }\end{array}$ & $\begin{array}{l}\text { Availability of persons } \\
\text { who agree to assist the } \\
\text { defendant; concerns } \\
\text { about possible } \\
\text { violation of law if } \\
\text { released }\end{array}$ \\
\hline
\end{tabular}

This adoption of factors from the criminal justice system in setting bonds raises several difficulties that reflect the failure of the immigration detention system to learn from the criminal justice system, even while mimicking it. First, the most important lesson learned in the criminal justice system is that significant empirical study is required in order to determine what factors predict risk sufficiently that they may be relied upon in making pretrial decisions. Yet, no such study supports the use of factors from the criminal justice system in the immigration context. Second, the immigration detention system adopts the criminal pretrial factors without imitating their use in the criminal justice system. In the criminal system, they are used to determine whether release is possible and, if so, to determine what types of support programs or requirements should be imposed after release; in the immigration system, the factors are used to set bond amounts, which in turn limits to varying degrees the possibility for eventual release even where release has been deemed viable enough for a bond to be set. As a result of the noncontextual adoption of the criminal justice pretrial factors, the factors have little value in the immigration pretrial detention context. They do not delimit the decision-making process to prevent arbitrary bond setting and unnecessary detention.

\section{a. Borrowing Without Consideration of Applicability}

In the criminal justice system, numerous empirical studies have been conducted over a period of decades to identify the factors that are predictive of a criminal defendant's likelihood of flight or risk to the community. ${ }^{210}$ As a result of this in-depth

210. See, e.g., Steven Jay Cuvelier \& Dennis W. Potts, State Justice Inst., Bail Classification Profile Project: Harris County, Texas (1993); Shima Baradaran \& Frank L. McIntyre, Predicting Violence, 90 TEX. L. REv. 497, 513-24 (2012) (describing previous studies and the current dataset used in an empirical study of predictors of pretrial risk of danger); Stevens H. Clarke, Jean L. Freeman \& Gary G. Koch, Bail Risk: A Multivariate Analysis, 5 J. Legal Stud. 341 (1976); Caleb Foote, Compelling Appearance in Court: Administration 
analysis, tools for risk assessment have been developed in order to take into account the most significant considerations in determining risk of flight or danger. These tools are subject to continued revision and development based on the research. They provide evidence-based guides for pretrial decisions. ${ }^{211}$

Information is broadly available about these empirically determined factors in the criminal pretrial justice system and the benefits of relying on them in making effective decisions regarding detention or release and imposing pretrial conditions. ${ }^{212}$ Criminal jurisdictions are encouraged to hew ever more closely to these relevant factors in making pretrial detention or release determinations. ${ }^{213}$ As with the move away from monetary bonds, the transition to an evidence-based risk assessment approach to pretrial decision making has not always been smooth. However, there is broad consensus among standard bearers in the criminal justice world that the change should occur. ${ }^{214}$

While borrowing specific pretrial factors from the criminal justice system, the immigration pretrial custody determination system has not followed the broader trend in criminal justice of emphasizing empirical study as a means of identifying relevant factors that will effectively aid decision making. No empirical research has taken place to identify factors that accurately predict the risk of flight or danger presented by a migrant in deportation proceedings. ${ }^{215}$

Nor can it simply be assumed that the factors that have been deemed reliable in the criminal context may also be utilized effectively in the immigration setting. In the criminal pretrial justice system, experts recommend that empirical analysis be conducted by each jurisdiction to ensure the predictive validity of specific factors to be used for pretrial decisions. ${ }^{216}$ If the same factors cannot be assumed to apply in different jurisdictions in the criminal justice context, the immigration system certainly requires a separate analysis of relevant factors from that conducted in the criminal justice setting.

At the broadest level, the purposes and characteristics of the criminal and immigration systems are sufficiently distinct to cause pause in the deployment of similar pretrial decision-making criteria in each. In the criminal justice system, the most

of Bail in Philadelphia, 102 U. PA. L. REV. 1031, 1034-36 (1954); VanNostrand \& Keebler, supra note 185.

211. See, e.g., PEPIN, supra note 180, at 7; VANNostrand, supra note 93, at 11-12; Kristin Bechtel, Christopher T. Lowenkamp \& Alex Holsinger, Identifying the Predictors of Pretrial Failure: A Meta-Analysis, 75 FED. РROB. 78, 78 (2011).

212. See, e.g., PePIn, supra note 180, at 7; Marie VanNostrand, Kenneth J. Rose, Kimberly Weibrecht, State of THE Science of Pretrial Release ReCommendations and SUPERVISION (2011); Bechtel et al., supra note 211.

213. See, e.g., CAlifornia Best Practices, supra note 180, at 9-13; PePin, supra note 180 , at 7-9.

214. See, e.g., ABA Pretrial Release Standards, supra note 130, at Standard 10-1.10; SCHNACKE, supra note 14 , at 88-90.

215. OIG REPORT ON AlternAtives to DETENTION, supra note 92, at 12 (noting a failure to assess the predictive capabilities of the ICE risk classification assessment tool by gathering critical outcomes information); see also GAO, ALTERNATIVES TO DETENTION, supra note 95, at 33 n.66 (acknowledging that ICE officials do not track basic data on those individuals who are released from detention or their compliance rates).

216. See Bechtel et al., supra note 211 , at 1 ; VANNostrand, supra note 93 , at 14. 
favorable result that can be obtained is a finding of no guilt, whereas in the immigration system an individual might not only avoid deportation but also gain status in the United States after attending hearings in immigration court. ${ }^{217}$ The incentives to appear at hearings are potentially very different and must be analyzed before the immigration system adopts the factors utilized to determine pretrial detention of criminal defendants.

For example, prior criminal history may predict the likelihood that an individual will appear in new criminal proceedings, ${ }^{218}$ perhaps because the criminal history relates to the individual's prior positive or negative experiences with the criminal justice system in ways that might impact future willingness to participate. However, immigration court deportation proceedings are civil, are adjudicated apart from criminal matters, and do not involve a potential criminal sanction. The criminal and immigration processes are so distinct that an individual's relation to the criminal process does not necessarily predict a relationship to immigration court deportation proceedings. ${ }^{219}$

Similarly, the predictive power of family or community ties ${ }^{220}$ may be weak for certain migrants in pending immigration court deportation proceedings. ${ }^{221}$ Recently arriving asylum seekers may have few or no existing ties in this country but may have every incentive to appear for hearings in order to seek refugee status and avoid deportation to a country where they may face physical harm or death. ${ }^{222}$ On the other

217. But see Peter H. Schuck, INS Detention and Removal: A "White Paper," 11 GeO. IMMIGR. L.J. 667, 671-72 (1997) (suggesting that criminal defendants may have more incentives to appear than migrants in deportation proceedings).

218. See, e.g., VANNostrand, supra note 93, at 14 (listing criminal history as a tested predictor of court appearance and/or danger to the community).

219. See Noferi \& Koulish, supra note 13, at 79-80 (noting that factors relating to criminal history "operate differently" in risk assessment in the immigration context, focusing on the likelihood that criminal history will be more recent in the criminal justice context) (emphasis omitted).

220. Although family ties and community ties are generally well accepted as valid considerations in the criminal setting, their predictive nature has been questioned even in the criminal pretrial context based on empirical study. See, e.g., Bechtel et al., supra note 211, at $80-81$.

221. Noferi \& Koulish, supra note 13, at 79 (suggesting that some individuals "may underreport family ties in an ICE interview for fear of relatives' deportation, a concern less present in criminal justice"). In their article assessing the effectiveness of ICE's risk classification assessment tool, Noferi and Koulish note similar problems with utilizing pretrial risk factors from the criminal justice system to make detention decisions in the immigration context and provide additional examples of the mismatch between immigration and criminal pretrial detention decision making, relating to employment history and other factors. Noferi \& Koulish, supra note 13 , at $78-81$.

222. See Refugee Act of 1980, Pub. L. No. 96-212, sec. 208, 94 Stat. 102, 105 (codified as amended at 8 U.S.C. $\S 1158$ (2012)) (setting out the asylum process); see also CATHRYN Costello \& Esra Kaytaz, Div. OF Int'L Protection, United Nations High Comm'R For

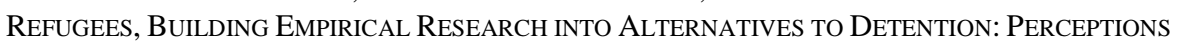
OF ASYluM-SEEKERS AND REFugEeS IN TORONTO AND GENEVA 7-8 (2013) (highlighting research demonstrating that asylum seekers are likely to appear for immigration court deportation proceedings). 
hand, some asylum seekers may face such a serious threat in their home country that they may fear appearing for immigration court hearings and running the risk of facing deportation, particularly if they have had negative interactions with the immigration system such that they do not trust its reliability in protecting them. Even if they have family members in the United States, they may have a strong incentive to avoid hearings and any other contact with immigration officials in order to minimize the possibility of returning to a dangerous situation. Despite these considerations, the factors of community and family ties are weighted heavily in the immigration custody determination process, ${ }^{223}$ having been copied years ago from the criminal justice system.

There are other institutional differences that make it unwise to import the factors used in criminal pretrial detention proceedings into the immigration custody determination process. In the criminal context, a criminal defendant will generally be appointed counsel if unable to afford a private attorney. ${ }^{224}$ This right does not apply to migrants in deportation proceedings in the immigration courts under current interpretation of the law. ${ }^{225}$ Migrants who are represented by counsel are more likely to attend their hearings, though. ${ }^{226}$ Migrants represented by counsel are significantly more likely to be successful in their immigration cases, thus incentivizing appearance. ${ }^{227}$ Immigration attorneys are also in a position to explain the proceedings

223. Guerra, 24 I. \& N. Dec. 37, 40 (B.I.A. 2006), 2006 WL 3337627, at*3.

224. See 18 U.S.C. $§ 3006$ A(a) (2012); Alabama v. Shelton, 535 U.S. 654, 661-62 (2002) (reaffirming general rule of right to appointed counsel while recognizing exceptions); Gideon v. Wainwright, 372 U.S. 335, 342-45 (1963). Criminal defendants are not necessarily entitled to counsel at the proceeding that determines detention. See Rothgery v. Gillespie Cty., 554 U.S. 191, 213-18 (2008) (Alito, J., concurring); Charlie Gerstein, Note, Plea Bargaining and the Right to Counsel at Bail Hearings, 111 MicH. L. REV. 1513, 1516 (2013). But here, I am discussing the effect of counsel in improving appearance at the merits stage.

225. 8 U.S.C. $\$ 1362$ (2012). But cf. J.E.F.M. v. Holder, 107 F. Supp. 3d 1119 (W.D. Wash. 2015) (No. C14-1026 TSZ), aff'd in part, rev'd in part, J.E. F.M. v. Lynch, Nos. 15-35738 \& 15-35739, 2016 WL 5030344 (9th Cir. Sept. 20, 2016) (litigation regarding the appointment of counsel for certain minors); Franco-Gonzalez v. Holder, No. CV 10-02211 DMG (DTBx), 2013 WL 8115423, at *1 (C.D. Cal. Apr. 23, 2013) (providing for counsel for individuals with mental competency issues). Press Release, Exec. Office for Immigration Review, U.S. Dep't of Justice, Department of Justice and the Department of Homeland Security Announce Safeguards for Unrepresented Immigration Detainees with Serious Mental Disorders or Conditions (Apr. 22, 2013), https://www.justice.gov/eoir/pages/attachments/2015/04/21 /safeguards-unrepresented-immigration-detainees.pdf [https://perma.cc/W6NB-UXNM] (providing for counsel for individuals with mental competency issues).

226. Human Rights First, Myth vs. Fact: Immigrant Families' ApPearance Rates in IMMIGRATION COURT (2015), http://www.humanrightsfirst.org/sites/default/files/MythvFact -Immigrant-Families.pdf [https://perma.cc/M3JE-Y3FG]; Eagly \& Shafer, supra note 6, at 73 (noting that over a six-year study period, only $7 \%$ of migrants in deportation proceedings with representation failed to appear for their hearings and received an in absentia order); Miriam Jordan, Most Migrants Make Their Court Date: Vast Majority Show Up to Deportation Hearings, U.S. Agency Says, WALl StREET J. (Oct. 7, 2014, 7:10 PM), http://online.wsj.com /articles/most-migrants-make-their-court-date-1412715818 [https://perma.cc/UP9D-8LNC].

227. NYIRS REPORT, supra note 7, at 1 (noting that migrants "facing deportation in New York immigration courts with a lawyer are $500 \%$ as likely to win their cases as those without representation"); Eagly \& Shafer, supra note 6, at 9 (noting that migrants represented by counsel were five-and-a-half times more likely to obtain relief from deportation); Schoenholtz \& 
to their clients and remind their clients of upcoming court dates. Because not all individuals are represented, the presence of a licensed attorney in the case may be a very relevant predictor of likelihood of appearance at hearings that would have no parallel in the criminal justice context.

There is a final important consideration that calls into question the applicability of criteria developed in the criminal pretrial detention context to the immigration custody determination process. Migrants involved in immigration court deportation proceedings are very diverse, and the diversity of the characteristics they present may very well affect predictability of risk. ${ }^{228}$ Each immigration case may involve very different deportation charges as well as potential outcomes based on a range of requests for relief from deportation that are available. For example, as noted above, family ties may not be a relevant factor for assessing the flight risk presented by an asylum seeker. On the other hand, family ties may be predictive of the likelihood of appearance at future hearings for a lawful permanent resident facing deportation after a criminal conviction. Such an individual may have every incentive to appear in court to fight deportation in order to achieve the right to remain with family in the United States. Family ties might even affect eligibility for certain forms of relief, which may also help predict future appearances, while being irrelevant for other forms of relief. ${ }^{229}$ This diversity of migrants in deportation proceedings makes it all the more necessary to evaluate the specific criteria or sets of criteria that will best predict flight risk and danger to the community for the full range of migrants impacted rather than relying on factors set in the criminal justice system.

\section{b. Misuse of the Borrowed Factors and Arbitrary Bonds}

Even if the criteria borrowed from the criminal justice system could predict risk accurately in the immigration pretrial detention context, the factors still would not lend themselves to the calculation of a bond amount. The identified factors "are not designed to assist in assigning an amount" of bond in the criminal pretrial context, because money bond is disfavored and has not been shown to be effective in addressing risk. ${ }^{230}$ Instead, the factors are used to determine the level of risk of flight or

Bernstein, supra note 195, at 55-56; Representation Makes Fourteen-Fold Difference in Outcome: Immigration Court "Women with Children" Cases, TRAC IMMIGRATION (July 15, 2015), http://trac.syr.edu/immigration/reports/396/ [https://perma.cc/T272-UQ79].

228. See Noferi \& Koulish, supra note 13, at 86-87 (pointing out the diversity problem with risk assessment in the immigration detention context).

229. See, e.g., 8 U.S.C. $§ 1229$ b(b) (2012) (providing for "cancellation of removal" for certain nonpermanent residents with close family ties in the United States and providing the opportunity for such individuals to obtain lawful permanent resident status).

230. CAlifornia Best Practices, supra note 180, at 12 (noting that there is no research to support a tie between bond and risk mitigation); see also ABA PRETRIAL RELEASE STANDARDS, supra note 130, at Standard 10-5.3(a) (establishing that financial conditions are treated as a last resort); PEPIN, supra note 180, at 2 (advocating for the use of nonfinancial release conditions); SCHNACKE, supra note 14, at 13 (noting that the "best research" available suggests that money bond "does not matter when it comes to either public safety or court appearance"); SCHNACKE, supra note 93, at 32 ("[E]xpecting money to effectively mitigate risk ... is historically unfounded."). 
danger presented and the possibility that measures other than detention could address any existing risks, in order to make an "in-or-out" decision regarding detention. ${ }^{231}$ In the criminal pretrial context, with its presumption of release, the risk assessment then dictates release unless the risk level is so high that it justifies exceptional resort to detention. ${ }^{232}$ If application of the pretrial factors reveals specific risk concerns in an individual case that do not justify detention, conditions of release, other than bond, can be set. ${ }^{233}$ Conditions are those that can be fulfilled after release (e.g., enrollment in support or monitoring programs). ${ }^{234}$

DHS and the immigration courts nonetheless use the factors in setting bond amounts, given the focus on bond setting in the immigration custody determination process. The factors are not used to decide release or detention, since detention is the default, nor are they used to set conditions to be followed after release to mitigate risk, given the heavy emphasis on bond as the main condition on release available.

The mismatch between the use of the pretrial criteria in the criminal pretrial justice and immigration contexts encourages arbitrariness in the immigration custody determination process. The factors adopted from the criminal justice context have nothing to say about particular levels of monetary bond that should be assessed. That is not their role or function. The criminal justice research not only fails to show a connection between imposition of monetary bond and pretrial compliance but also finds no confirmation that particular bond amounts are more effective at preventing certain risks of flight or danger than others. ${ }^{235}$ Because the pretrial factors provide no meaningful standards for bond setting, DHS and the immigration courts set bond

231. SCHNACKE, supra note 93, at 41-44 (clarifying that the pretrial custody decision should be "an in-or-out" decision to be immediately effectuated without the imposition of monetary bond, which may delay or prevent release); see also 18 U.S.C. § 3142(c) (2012) (listing possible conditions on release while providing that a "financial condition" may not be imposed if it "results in ... pretrial detention"); 18 U.S.C. $§ 3142(\mathrm{~g})$ (listing factors to be considered in determining whether release is possible).

232. SCHNACKE, supra note 14, at 90 (explaining that pretrial risk assessments are used to help judges "with maximizing . . release" while detaining those who should be detained).

233. See SCHNACKE, supra note 93, at 41-44 (clarifying that the imposition of monetary bond, aside from being of questionable effectiveness, delays or prevents release in frustration of the in-or-out decision).

234. See id. at 44 (clarifying that any flight risk or public safety concerns should "be addressed after release through conditions that are designed to reasonably mitigate that risk" (emphasis in original)). The criminal jurisdictions that have implemented pretrial risk assessment tools are generally jurisdictions that no longer make heavy use of bond yet still achieve high appearance rates. See id. at 59-62. Because the risk factors are not designed to set bond but rather to identify other appropriate conditions of release, those jurisdictions that regularly impose bonds often do so based not on those factors but on arbitrary bond schedules, which set amounts based on the crime charged. See Justice PoliCy InST., supra note 31, at 22-23.

235. California Best Practices, supra note 180, at 12; see also Justice Policy Inst., supra note 31, at 22 ("[D] espite the use of money bail at increasingly higher amounts, failure to appear rates have not changed substantially."); SCHNACKE, supra note 14, at 13 (identifying difficulty in establishing how one bond amount would be more effective at addressing risk than another); VANNOSTRAND ET AL., supra note 212, at 2 (noting that research on establishing risk is well established but research is still new on determining what pretrial conditions offer the best match with particular risks). 
amounts arbitrarily. ${ }^{236}$ The bond requirements then lead, all too often, to continued detention without connection to identified flight risk or danger to the community.

Thus, while nominally using pretrial risk factors in the custody determination process, DHS has offered no guidance to its officials establishing when those factors would dictate that monetary bond should be imposed as a condition of release rather than release or detention alone, nor has DHS indicated when the minimum $\$ 1500$ bond amount should be imposed or when other levels of bond would be proper. ${ }^{237}$ The bond amounts imposed by DHS are necessarily lacking in rationality and connection to specific risk considerations that suggest the potential for flight or danger.

In the absence of any meaningful guide to decision making other than the presumption of detention, DHS also regularly sets across-the-board bond amounts for entire groups in its initial custody determinations. ${ }^{238}$ These determinations necessarily lack any logical relation to identified risk, because they treat all migrants the same when differences must exist. DHS sets the same bond amounts for all individuals in custody at a particular detention facility or in a particular region during a specific time period. For example, DHS issued instructions that bonds should be set at the same amount of $\$ 7500$ for virtually all of the asylum-seeking women held at the T. Don Hutto Residential Center in Taylor, Texas, ("the Hutto facility") for a period during 2013, and bonds were consistently set at the $\$ 7500$ mark. ${ }^{239}$ Then, instructions were issued that bonds at the Hutto facility and other facilities in the same detention region should be set at $\$ 3000$ because the available bed space was nearly filled, and bonds were set or reduced to $\$ 3000$ before increasing again after a

236. Cf. SCHNACKE, supra note 14, at 13 (noting arbitrary nature of decision regarding particular bond amount).

237. The risk assessment tool deployed by DHS is very limited in its ability to make recommendations about release on bond. See Risk ClASSIFICATION ASSESSMENT, supra note 92, at 4 (stating only that, if the risk assessment tool "produces a recommendation to detain the alien, the recommendation will also indicate whether the alien is eligible for release on bond").

238. See, e.g., ACLU Letter Regarding High Bonds, supra note 30, at 2; E-mail from [REDACTED], ICE/Enforcement and Removal Operations Assistant Field Office Director, to [REDACTED] (Apr. 17, 2014) (hereinafter Apr. 17, 2014 ICE e-mail) (e-mail obtained through FOIA response to National Immigrant Justice Center on file with the Indiana Law Journal) (sending instructions of the director for the San Antonio, Texas, detention region: "Effective tomorrow (4-18-2014) Bonds will go up from the previous $\$ 7,500.00$ to $\$ 10,000.00 . ”) ;$ E-mail from [REDACTED] to [REDACTED] (April 18, 2014, 3:44 PM) (e-mail obtained through FOIA response to National Immigrant Justice Center on file with the Indiana Law Journal) (advising of ICE headquarters "guidance" that "Credible Fear cases bond amount will increase to $\$ 7,500.00 ")$.

239. U.S. DeP't of Homeland SeCurity, Redacted Forms I-286: Notice of Custody DETERMINATION [hereinafter HutTO I-286 FORMS] (completed forms for women detained at the Hutto Facility on file with the Indiana Law Journal) (documenting $\$ 7500$ bond amounts set in multiple cases for individuals from from different countries during the late July-early September 2013 period); E-mail from [REDACTED] to [REDACTED] (July 22, 2013, 7:20 AM) (e-mail obtained through FOIA response to Denise Gilman on file with the Indiana Law Journal) (establishing a policy that DHS would set $\$ 7500$ bond for individuals detained at the Hutto facility who had passed a screening interview to establish a viable asylum claim and who could show identification; establishing a policy of denying release ("NO BOND") where identification unavailable). 
period. ${ }^{240}$ Bond setting for Central American mothers and children apprehended at the Southwest border provide another example. After an initial period when DHS insisted on continued detention without potential for release on bond, ${ }^{241}$ DHS began setting across-the-board bond amounts as a condition of release. For several months, DHS set bonds for almost all women detained with their children at the Karnes City, Texas, detention facility at either $\$ 7500$ or $\$ 10,000 .{ }^{242}$ These categorical bonds are not related to individual flight risk or danger considerations and so must be seen as arbitrary.

Immigration court review, through custody redetermination hearings, does not resolve the arbitrariness of the bonds set in initial DHS custody determinations either. The leading case law on custody redetermination proceedings from the Board of Immigration Appeals provides no guidance to the immigration courts as to how the specified custody determination factors are to be weighed or applied in determining bond amounts. ${ }^{243}$ The average bond amounts set by different immigration judges vary greatly without any apparent explanation for the disparities. ${ }^{244}$ Given the wide discretion offered to immigration judges in custody redetermination hearings and the lack of direct judicial review, there is little likelihood that arbitrary bonds set by DHS and the immigration courts will be corrected.

The bond requirement imposed by DHS or the immigration courts is often not just arbitrary, but arbitrarily high. ${ }^{245}$ Many release-eligible migrants thus remain detained for extended periods or throughout their deportation proceedings because of inability to pay a bond that was imposed. ${ }^{246}$ Their detention is not justified, because DHS or the immigration courts have explicitly found that release is possible and detention is not the only viable means of preventing flight or danger in their cases, by allowing

240. Sept. 17, 2013 ICE e-mail, supra note 111 (describing a teleconference during which DHS officials stated that the San Antonio detention region, which encompasses the Hutto facility and other facilities, was close to "maximum bed space capacity" and setting a policy of imposing $\$ 3000$ bond for asylum seekers in detention who had identification and had passed the screening interview to establish a viable claim); Apr. 17, 2014 ICE e-mail, supra note 238 (sending instructions of the director for the San Antonio, Texas, detention region: "Effective tomorrow (4-18-2014) Bonds will go up from the previous $\$ 7,500.00$ to $\$ 10,000.00$.”); see also HutTo I-286 ForMs, supra note 239 (documenting $\$ 3000$ bond amounts set in multiple cases after September 17, 2013).

241. R.I.L-R v. Johnson, 80 F. Supp. 3d 164, 170-71 (D.D.C. 2015); Declaration of Barbara Hines, R.I.L-R, 80 F. Supp. 3d 164.

242. See ACLU Letter Regarding High Bonds, supra note 30.

243. See, e.g., Guerra, 24 I. \& N. Dec. 37, 40 (B.I.A. 2006), 2006 WL 3337627, at*3.

244. See, e.g., Ryo, supra note 13, at 133 (finding significant differences among bond amounts set by different immigration judges in custody redetermination hearings held in central California for a specific category of migrants who had received their hearings as a result of a federal court order).

245. See NYIRS REPORT, supra note 7, at 13; ACLU Letter Regarding High Bonds, supra note 30; E-mail from [REDACTED], Supervisory Detention \& Deportation Officer, South Texas Detention Complex, to Docket Officers, (Mar. 6, 2014, 9:17 PM) (e-mail obtained through FOIA response to National Immigrant Justice Center on file with the Indiana Law Journal) (supervisory DHS detention officer at a particular facility issuing guidance to all DHS officials indicating that bond "should be set at a minimum of $\$ 7500$ " (emphasis added)).

246. NYIRS REPORT, supra note 7, at 13-14. 
for release upon payment of bond. ${ }^{247}$ By nonetheless insisting on the payment of an unattainable bond as a condition for release, rather than identifying other measures that would permit release and also address any specific identified risks, detention continues without adequate justification.

3. The Overall Impact of Selective Borrowing from the Criminal Justice System on the Potential for Liberty

In addition to detaining as a default, then, the immigration custody determination process also fails to ensure subsequent release where detention is not necessary to prevent specific risk of flight or danger. With money bond as their only real tool in the custody determination process, and lacking meaningful criteria for determining risk or standards for setting bond amounts, DHS and the immigration courts impose arbitrary bond requirements that impede, if not prevent, release.

The problems inherent in selective borrowing from the criminal pretrial justice system are compounded by the lack of any legal support for the emphasis on monetary bonds in the immigration pretrial detention context. The blindered focus on monetary bonds is nowhere mandated by law and has not received constitutional approval from the courts. ${ }^{248}$ Meanwhile, international bodies have expressed concern about the use of monetary bonds because of the likelihood that they will lead to unjustified detention. ${ }^{249}$ The reliance on money bonds, which are set arbitrarily, has an unacceptable negative impact on liberty.

\section{IMPLICATIONS OF THE FAILED CUSTODY DETERMINATION PROCESS}

In combination, automatic and nonindividualized detention and selective adoption of problematic elements of the criminal pretrial justice model result in widescale detention of release-eligible migrants during pending immigration court deportation proceedings. The custody determination process for release-eligible migrants in immigration court deportation proceedings has floated so far adrift of its legal and theoretical moorings that the right to liberty is seriously compromised. ${ }^{250}$ Lacking

247. Cf. SCHNACKe, supra note 93, at 61-62 (noting, in the criminal justice context, that individuals who an adjudicator has determined may be released, albeit on a condition, should not then be detained as a result of a monetary bond requirement).

248. See, e.g., Casas-Castrillon v. Dep't of Homeland Sec., 535 F.3d 942, 951-52 (9th Cir. 2008) (ordering bond hearing as the forum for migrants to "challenge the necessity of [their] detention" but saying nothing about the role of monetary bond); Shokeh v. Thompson, 369 F.3d 865, 871-72 (5th Cir.) (holding that bond amount must be reasonable and "that a bond that has the effect of preventing an immigrant's release because of inability to pay ... is presumptively unreasonable"), vacated as moot, 375 F.3d 351 (5th Cir. 2004); Gordon v. Johnson, 300 F.R.D. 28, 30 (D. Mass. 2014) (ordering bond hearing to provide the opportunity to argue for release without mentioning monetary bond).

249. IACHR REPORT ON DETENTION, supra note 2, at 82.

250. See Zadvydas v. Davis, 533 U.S. 678, 690-91 (2001) (affirming the central role of liberty and the exceptionality of detention in the immigration context and explaining that deprivation of liberty requires "special justification," usually to address flight risk or danger to the community); $c f$. Foucha v. Louisiana, 504 U.S. 71, 80 (1992) (emphasizing that detention, which is not based on criminal punishment after trial, is allowed only in narrow nonpunitive 
conscientious adherence to the limits of civil administrative detention, the system veers impermissibly into the realm of arbitrary and punitive restriction on liberty in violation of constitutional and human rights standards. ${ }^{251}$ Rectification is required on this basis alone to restore limits on immigration detention and proper respect for liberty.

The contorted interaction between the immigration and criminal justice pretrial detention systems, described above, ${ }^{252}$ also creates the potential for serious erosion of liberty standards for all. The differences between immigration and criminal systems are ignored when those differences might favor migrants and are magnified when they can explain lesser consideration of liberty concerns for migrants.

Thus, it is assumed that pretrial detention structures are appropriate for migrants in pending immigration court deportation proceedings because of their use in the criminal pretrial context. ${ }^{253}$ Migrants are treated as similar to criminals simply because of their status as noncitizens in immigration court deportation proceedings. ${ }^{254}$ Yet, migrants in detention pending immigration court deportation proceedings are not facing criminal charges; many are refugee protection seekers or others with no criminal history at all, while some have minor criminal histories but have already served any criminal sentence imposed. These migrants may well present fewer dangers to the public and the adjudicatory process than criminal defendants. ${ }^{255}$

On the other hand, immigration court deportation proceedings are treated as distinct from the criminal process for the purpose of incorporating protections and lessons learned from the criminal pretrial justice experience, such as prompt, independent, and careful scrutiny of detention decisions and the move away from monetary bond. The immigration system is distinguished as involving civil, rather than criminal, consequences. ${ }^{256}$ The unique status of migrants as noncitizens whose treatment may raise national sovereignty considerations, including control of borders and international affairs, is also invoked. ${ }^{257}$ On this view, sharp distinctions are made between citizens and migrants and between the immigration system and criminal justice processes. However, these distinctions are suspect, since the consequences of

circumstances); United States v. Salerno, 481 U.S. 739, 755 (1987) (affirming that "liberty is the norm, and detention prior to trial or without trial is the carefully limited exception").

251. See Zadvydas, 533 U.S. at 690.

252. See supra Parts II.A-B.

253. See Wong Wing v. United States, 163 U.S. 228, 235 (1896) (justifying detention for immigration purposes on the grounds that "[d] etention is a usual feature of every case of arrest on a criminal charge").

254. See Unlocking Human Dignity, supra note 7, at 163-64, 172 (noting that "[d]etention brands immigrants as criminals . . . and contributes to the sense that they deserve to be treated as such").

255. See SCHRIRO, supra note 58, at 2, 4, 21 (noting that immigration detainees present low risks, given their motivation to participate in their immigration court proceedings, and so should not be treated similarly to individuals in the criminal incarceration system).

256. INS v. Lopez-Mendoza, 468 U.S. 1032, 1038 (1984).

257. See, e.g., Demore v. Kim, 538 U.S. 510, 522-23 (2003) (“Congress may make rules as to aliens that would be unacceptable if applied to citizens," and "detention during deportation proceedings [is] a constitutionally valid aspect of the deportation process."); Reno v. Flores, 507 U.S. 292 (1993) ("Congress has the authority to detain aliens suspected of entering the country illegally pending their deportation hearings." (citation omitted)). 
deportation proceedings can be as severe as a criminal conviction. Also, noncitizens may have strong claims to recognition of status as members of the national community, after having lived in the United States for many years and developing strong family and community ties or by presenting valid refugee claims countenanced in U.S. law. Further, migrants may be caught up in both immigration and criminal proceedings. ${ }^{258}$ In any case, both criminal and immigration pretrial detainees are held in nonpunitive administrative detention, which involves a single constitutional framework.

This process of unprincipled comparing and contrasting of the immigration and criminal justice systems promotes the weakest possible understanding of liberty and the limits on administrative detention not imposed as punishment after a criminal trial. The weakening of liberty standards harms release-eligible migrants facing pretrial immigration detention but may also have even broader negative impacts for administrative detention in general, including in the criminal justice pretrial detention context. The impetus to detain migrants easily leads to new levels of criminal pretrial detention where non-citizens are involved. ${ }^{259}$ At a systemic level, if left unchecked in the immigration context, patterns of unnecessary deprivation of liberty may extend beyond immigration detention to make it increasingly difficult to insist on limitations on administrative detention in the pretrial criminal detention context and elsewhere. Efforts in the criminal pretrial justice realm to improve adherence to the principles of exceptional pretrial detention, and thus address one aspect of mass incarceration, may be damaged.

More immediate and concrete concerns exist, as well. The current flawed pretrial immigration detention system creates significant harm for detained migrants and their families as well as the larger community. These may be harms that would be acceptable if absolutely necessary to ensure the integrity of the immigration process but should be avoided where, as here, a showing of need is lacking on a systematic basis.

The damage to detainees created by unnecessary restrictions on liberty is great. In addition to the inherent damage to human dignity caused by the deprivation of liberty, detention has negative impacts on the physical and emotional health of the migrant in detention. ${ }^{260}$ Many migrants in deportation proceedings have experienced

258. See Fong Yue Ting v. United States, 149 U.S. 698, 740 (1893) (Brewer, J., dissenting).

259. This relationship already has had its impact. An increase in pretrial detention in criminal cases at the federal level is directly attributable to the high rates of pretrial detention of migrants facing criminal charges. See Thomas H. Cohen, OfFice of Justice Programs, U.S. Dep't. of Justice, NCJ-239673, Pretrial Detention and Misconduct in Federal District COURTS, 1995-2010 3 (2013) ("Growth in the number of pretrial detentions was driven primarily by immigration caseloads.”); COHEN, supra note 156, at 11 (noting that U.S. citizen defendants were much more likely to be released from pretrial criminal detention than noncitizens); MotiVANS, 2011-2012 FEDERAL JustiCE STATISTICS, supra note 15, at 3 (noting that nearly half of federal criminal defendants booked into detention by the U.S. Marshals Service were charged with immigration offenses such as illegal entry).

260. Allen S. Keller, Barry Rosenfeld, Chau Trinh-Shevrin, Chris Meserve, Emily Sachs, Jonathan A Leviss, Elizabeth Singer, Hawthorne Smith, John Wilkinson, Glen Kim, Kathleen Allden \& Douglas Ford, Mental Health of Detained Asylum Seekers, 362 LANCET 1721, 1722 (2003) (explaining that "detaining asylum seekers exacerbates symptoms of depression, anxiety, and post-traumatic stress disorder"); Unlocking Human Dignity, supra note 7, at 163-64, 
trauma, including torture and sexual abuse, or have mental health difficulties or other vulnerabilities. ${ }^{261}$ Detention, for relatively short time periods as well as for prolonged time periods, can cause even greater harm to such individuals. ${ }^{262}$ As noted above, it is also much more difficult for detained migrants to obtain counsel and to succeed on their claims, meaning that some individuals who might otherwise be found entitled to remain in the United States will instead be deported. ${ }^{263}$ Detention damages the families left behind when relatives are deprived of liberty as well. ${ }^{264}$

There is also significant harm to the community when the custody determination process does not ensure that those detained are those most likely to present a flight risk or danger. The public and the legal system benefit from detention that addresses situations in which migrants present serious risks of flight or danger that cannot be prevented except through restrictions on liberty. However, it is also in the community's interest not to detain where unnecessary, particularly because detention of migrants is a very expensive endeavor. ${ }^{265}$ Where some reasonable concern about

172-74 (summarizing findings that detention may lead to "pervasive despair" and other mental health problems); Nina Bernstein, Documents Reveal Earlier Immigrant Deaths, N.Y. TIMES (Jan. 9, 2010), http://www.nytimes.com/2010/01/10/nyregion/10detainside.html?_r=0 [https://perma.cc/SJ6W-XQWC].

261. See, e.g., COMm'N On Immigration, Am. BAR Ass'n, FAmily Immigration Detention: Why the PAst CANnot Be Prologue 32-33 (2015), http://www.americanbar.org /content/dam/aba/publications/commission_on_immigration/FINAL\%20ABA\%20Family \%20Detention\%20Report\%208-19-15.authcheckdam.pdf [https://perma.cc/28MD-9VW5] (noting that families in immigration detention often have vulnerabilities that make detention particularly problematic); Letter from Michael M. Honda \& Raúl M. Grijalva, Representatives, U.S. House of Representatives, to Jeh Johnson, Sec'y, Dep't of Homeland Sec. (June 23, 2015), http://grijalva.house.gov/uploads/2015_6_23_LGBT_Detainee_Letter.pdf [https://perma.cc/VY6Y-4MHE] (expressing concerns about numbers of lesbian, gay, bisexual, and transgender individuals in immigration detention and their vulnerabilities).

262. See, e.g., Declaration of Luis H. Zayas at 2-3, R.I.L-R v. Johnson, 80 F. Supp. 3d 164 (D.D.C. 2015) (No. 1:15-cv-00011-JEB).

263. See supra notes 194-96, 227 and accompanying text.

264. See Kalina Brabeck, M. Brinton Lykes \& Stuart L. Lustig, The Psychosocial Impact of Detention and Deportation on U.S. Migrant ChildREn AND Families: A REPORT FOR THE INTER-AMERICAN HUMAN RIGHTS COURT 4 (2013), https://www.bc.edu /content/dam/files/centers/humanrights/doc/IACHR\%20Report\%20on\%20Pyschosocial\%20Impact \%20of\%20Detention\%20\%20Deportation-FINAL\%208-16-13.pdf [https://perma.cc/9KN5-TL8U]; Ajay Chaudry, Randy Capps, Juan Manuel Pedroza, Rosa Maria Castañeda, Robert Santos \& Molly M. Scott, The Urban Inst., Facing Our Future: Children in the AFTERMATH OF IMMIGRATION ENFORCEMENT 27-53 (2010), http://www.urban.org/sites/default /files/alfresco/publication-pdfs/412020-Facing-Our-Future.PDF [https://perma.cc/5GRD-V5E3] (documenting harms to children whose parents were arrested in immigration enforcement actions); Luis H. ZAYAS, ForgotTen Citizens: DePortation, ChiLdREN, AND the MAKing OF AMERICAN EXILES AND ORPHANS (2015); Kalina Brabeck \& Qingwen Xu, The Impact of Detention and Deportation on Latino Immigrant Children and Families: A Quantitative Exploration, 32 HisP. J. BEHAV. SCI. 341, 345-46, 354-55 (2010) (documenting increased mental health difficulties of U.S. citizens and other family members of migrants subject to detention and deportation).

265. 2015 ICE BUdGET REQUEST, supra note 105, at 39 (page 1287 in full version of DHS Budget Request) (budget for detention operations was almost $\$ 2$ billion during the last several fiscal years). 
risk of danger or flight exists, it is desirable to determine whether there are means of mitigating that risk in ways that are less expensive than detention, both in financial and human costs.

Yet, because of its presumptive application of detention and its reliance on arbitrary monetary bond requirements as the only option for obtaining release, the current system does a poor job of sorting out those migrants who require detention from those who could be released altogether or with conditions imposed after release to address specific risk factors. Overdetention is the main result. ${ }^{266}$ However, there may also be underdetention in some cases. The automatic and arbitrary detention described in this Article affects individuals who are apprehended by immigration authorities, but a good number of migrants who might be subject to immigration court deportation proceedings are never detained at all and in some cases might actually present greater risks than those detained. It is also possible that the focus on monetary bonds allows wealthier migrants to achieve release from detention relatively promptly, albeit still after some period of detention. Some of these migrants may present risks not presented by migrants who remain detained. ${ }^{267}$ The cost to the community is significant under a system that fails to detain when, and only when, necessary.

\section{A NORMATIVE RESPONSE AND A CALL FOR ADDITIONAL RESEARCH}

A normative response is required to address the failures of the immigration custody determination process that lead to such dire results. Reforms should be undertaken to restore restraint in the immigration pretrial detention scheme for releaseeligible migrants and to impose logic and legality in the custody determination process. Such reform will require changes in the legal and practical framework for the custody determination system as well as additional research and inquiry.

\section{A. Reestablishing Presumptive Liberty and Individualized Review}

The constitutional right to liberty must regain its foothold in order to begin a meaningful reform process. The very nature of the immigration pretrial custody determination process must change so that liberty is at the center. To meet the requirements of civil detention, the role of the system should be to ensure that detention is strictly limited and that release after initial apprehension and processing is achieved wherever possible. All actors involved with the custody determination process will need to recognize the current reality of a system that focuses on automatic detention and then on troubling monetary bond setting, rather than on liberty itself.

266. See Kalhan, supra note 10 , at 48 .

267. See EOIR Statistics Yearbook 2015, supra note 5, at P2 (showing that some migrants are never detained during immigration court deportation proceedings including some who fail to appear for their hearings); LAURA AND JOHN ARNOLD FOUND., supra note 188, at 1 (noting that arbitrary and nonindividualized decisions regarding pretrial detention lead to release of "defendants who are high-risk and/or violent" along with unnecessary detention of defendants who present low risk); Wiseman, supra note 179, at 1361-62 (noting, in the criminal justice context, that affluent individuals may achieve release after paying bond even though they present at least as significant a risk as those who cannot afford to pay bond and achieve release). 
To avoid further entrenchment of the current reality, the custody determination process should not be posited as a model of individualized decision making regarding detention. While the custody determination process offers a substantial benefit to those in mandatory detention who have been denied any opportunity for release, it is nonetheless deeply flawed. ${ }^{268}$ Describing the custody determination process as a remedy for liberty violations, rather than as a problem, makes it more difficult to critique and reform the system. ${ }^{269}$ The process should be dramatically changed before deployment in any setting in order to protect liberty.

In addition, the very language used to describe and discuss the custody process should be modified to reflect and motivate the required paradigm shift. If the language of the entire system accepts the central place of detention and monetary bond, then it will be near impossible to re-envision the role of the system as one dedicated to individualized release decisions. New and consistent terminology should be developed to better describe the critical decisions made in the process. For example, the commonly used terms "bond proceedings," "bond eligible," and "no bond" might be replaced with "custody determination process," "release or review eligible," and "detention determination."

In the process itself, reform requires that detention as the default give way to a presumption of release. It must be recognized that detention is not necessary as a general matter, because most migrants in deportation proceedings do not present a meaningful risk of flight or danger to the community that could justify detention. Such a shift will require a change in legal norms as well as a shift in the way the government conceives of detention for release-eligible migrants in pending immigration court deportation proceedings. ${ }^{270}$ The result would undoubtedly be a significant reduction in the numbers of release-eligible migrants who are detained.

268. See, e.g., Rodriguez III, 804 F.3d 1060, 1087-88 (9th Cir. 2015) (recognizing that additional protections are necessary after prolonged mandatory detention to make the custody determination process adequately protect liberty and ensure meaningful individualized determinations of the necessity of continued detention), cert. granted sub nom. Jennings v. Rodriguez, 136 S. Ct. 2489 (2016). But cf. Sopo v. U.S. Att'y Gen., 825 F.3d 1199, 1218-1220 (11th Cir. 2016) (applying the procedures and burden of proof from ordinary custody determination process even in cases of prolonged mandatory detention).

269. For example, cases holding that "arriving" aliens should be permitted to participate in immigration court custody redetermination hearings after prolonged detention without review suggest that the custody determination process is sufficient to remedy serious liberty violations outside of the mandatory detention context. These decisions ignore the immediate liberty rights and protections that such release-eligible migrants should enjoy and instead make their freedom subject to a flawed custody determination process even after prolonged unjustified detention. See, e.g., Maldonado v. Macias, 150 F. Supp. 3d 788, 791, 812 (W.D. Tex. 2015) (condoning an immigration court bond hearing as providing adequate protections to an "arriving" asylum seeker after years of detention).

270. See Unlocking Human Dignity, supra note 7, at 163 (noting that "[d]etention is treated as a pillar of the US immigration enforcement system" when other means exist to meet immigration objectives). The regulation that places the burden on the detained migrant to justify release would need to be modified, and the case law of the BIA would need to return to one that presumes release without requirement of bond. See, e.g., 8 C.F.R. 236.1(c)(8) (2016) (providing that, currently, burden is on the detained migrant to justify release); Guerra, 24 I. \& N. Dec. 37, 40 (B.I.A. 2006), 2006 WL 3337627, at *3 (same). 
In line with ensuring that detention is utilized only when necessary, genuine individualized determinations of necessity must be made before detention is imposed at the initial custody determination stage. DHS should immediately release apprehended migrants on their own recognizance or conditional parole, after basic processing, unless there are "red flags" in an individual case that suggest a risk of flight or danger that cannot be addressed by means other than detention. This is the only way to ensure that liberty is the rule and detention the exception, thereby respecting the principles of limited civil detention. ${ }^{271}$ In addition, where release is not immediately possible, DHS must conduct periodic reviews of the detention to ensure that it is still necessary.

Restoring liberty as the general rule also requires careful scrutiny of any conditions on release to ensure that they do not implicate unnecessary constraints on freedom. ${ }^{272}$ Money bond should be strongly disfavored, since a monetary bond requirement does not effectuate immediate release and does not effectively ameliorate risks of flight or danger to the community. ${ }^{273}$ DHS should use monetary bond as a condition of release only as the last resort. ${ }^{274}$ Financial requirements should be used only where bond can address an identified risk that would not be addressed through release alone or release on other conditions that do not require any additional detention. The use of bond will be a rare circumstance given the low likelihood that monetary bond diminishes risk where such risk exists.

This rejection of the primary role of monetary bond will require acknowledgment that release on recognizance is proper and appropriate in most cases where release is possible because there is no identified risk great enough to require detention. Furthermore, if monetary bond is required, it should be set at a nominal amount and should take into account the ability of the migrant to pay so that it does not result in unjustified detention rather than immediate release. ${ }^{275}$

In moving away from the use of monetary bonds, DHS should turn to liberty and not to alternative methods for ensuring detention or restrictions on liberty upon

271. See Demore v. Kim, 538 U.S. 510, 532-33 (2003) (Kennedy, J., concurring); Zadvydas v. Davis, 533 U.S. 678, 690-92 (2001).

272. An "in-or-out" custody decision is the recommended approach for pretrial decisions in the criminal justice system. SCHNACKE, supra note 14, at 42-43, 54; SCHNACKE, supra note 93 , at 11-12.

273. See SCHNACKE, supra note 14, at 12-13; SCHNACKE, supra note 93, at 32.

274. See ABA PRetrial Release StANDARds, supra note 130, at Standard 10-5.3 (identifying bond as a last alternative for release).

275. See 18 U.S.C. $§ 3142$ (c)(2) (2012) ("The judicial officer may not impose a financial condition that results in the pretrial detention of the person.”); ABA PRETRIAL RELEASE STANDARDS, supra note 130, at 10-5.3(a) (providing that bond should not result in detention). To be effective at all, monetary bond would need to be calculated at the edge of affordability for a particular migrant. See Karnow, supra note 176, at 23. The vast majority of migrants in immigration court deportation proceedings have sufficiently low incomes that the edge of affordability would probably be the minimum bond amount. Litigation has recently been filed challenging the failure of the custody determination process to consider a migrant detainee's ability to pay in setting bond. Complaint-Class Action III 1-2, Hernandez v. Lynch, No. 5:16cv-00620-JGB-KK (C.D. Cal. Apr. 6, 2016). This litigation might help ensure that bond is set at an appropriate level to minimize detention, where imposed, but does not address the underlying problem of undue reliance on monetary bond. 
release. Particular attention should be paid to the risk that electronic monitoring or other intrusive monitoring requirements might become a substitute for detention. While such monitoring may allow for immediate release from detention, it nonetheless functions as a restriction on liberty. ${ }^{276}$ In addition, as mentioned above, the effectiveness of such monitoring in addressing flight risk or danger is not established. ${ }^{277}$ Imposition of intensive monitoring for individuals identified as low risk may even lead to worse pretrial compliance outcomes. ${ }^{278}$ Monitoring may not then be used automatically or as a default, even when it serves as a replacement for full physical custody. It must only be used where an individualized determination establishes it to be a necessary and effective tool for addressing the particular risks presented in a case that preclude release without conditions, which is likely to be an exceptional circumstance.

To ensure that detention is limited to those situations where it is actually needed, the immigration courts should automatically and promptly review any cases in which DHS orders detention or imposes a bond requirement. The immigration court custody redetermination hearing should take up the central issue of the need to detain rather than limiting itself to consideration of monetary bond. The immigration courts should be clearly empowered to release immediately on recognizance or otherwise without payment of any monetary bond. They should enjoy adequate independence to carry out that role. The right to automatic review of detention before the immigration courts should extend to all individuals in pending deportation proceedings who are not subject to mandatory detention by statute on criminal grounds. The review should apply to those treated as "arriving aliens" and to those in withholding-only proceedings after a final deportation order as well as other release-eligible migrants. ${ }^{279}$

276. See, e.g., United States v. Torres, 566 F. Supp. 2d 591, 601-02 (W.D. Tex. 2008) (requiring individualized determination of need for specific pretrial condition under constitutional liberty standards); UNHCR DETENTION GUIDELINES, supra note 63, at 22-23 (stating that electronic monitoring and similar programs that restrict liberty should be subject to individualized review of their necessity). But cf. Zavala v. Prendes, No. 3-10-CV-1601-K-BD, $2010 \mathrm{WL} 4454055$, at $* 2$ (N.D. Tex. Oct. 5, 2010) (holding that imposition of ankle monitor did not violate due process); Nguyen v. B.I. Inc., 435 F. Supp. 2d 1109, 1115-16 (D. Or. 2006) (holding that placement of migrants in intensive supervision program, including electronic monitoring, did not violate due process rights).

277. See Oig Report on Alternatives to Detention, supra note 92, at 8; GAO, Alternatives to DETENTION, supra note 95, at 30-32 (finding that data establishes high appearance rates for electronic monitoring deployed along with case management services but does not establish whether electronic monitoring itself improves appearance rates); accord VANNOSTRAND ET AL., supra note 212, at 24-27 (noting similar lack of data establishing effectiveness of electronic monitoring in the pretrial criminal justice context).

278. See VanNostrand \& Keebler, supra note 185, at 17. Imposition of such intrusive requirements on low-risk individuals leads to a sense of alienation and a feeling that the system is not just, thereby creating a disincentive for cooperation. Electronic monitors also stigmatize the wearers, making it more difficult to integrate into communities and thus more difficult to comply with the obligations imposed. E.g., Gogolak, supra note 171.

279. See Unlocking Human Dignity, supra note 7, at 166 (making similar recommendation for automatic judicial review of detention in all cases). Minor changes to existing regulations 


\section{B. Determining Risk Factors and Designing Measures To Address Identified Risk}

The process for determining the risk presented by migrants must be made rational. Rigorous research must form the basis of the process for deciding, in a given case, whether outright release is possible, whether additional mechanisms must be deployed to address specific identified risk factors, or whether the risk is so great and unmanageable that detention is required. An agenda for empirical research should be prepared to address two components: (1) which factors best predict flight and danger in the immigration setting, and (2) what conditions may effectively ameliorate the risks presented without resorting to detention. The research should consider these questions with due attention to the range of different migrants who might be found in deportation proceedings. As this research agenda moves forward, certain reforms to the custody determination process should be adopted based on a considered evaluation of the existing limited information available regarding risk factors and mechanisms for addressing them without detention.

\section{Risk Factors}

All of the pretrial factors currently used in the immigration custody determination process, most having been borrowed from the criminal pretrial justice system, must be evaluated to determine whether and to what extent they predict flight risk or danger in different groups of migrants. In addition, though, the research should also consider factors not currently utilized, which might be relevant to determining risk in the immigration context.

It is likely that some factors that currently play little or no official role in the custody determination process may predict risk more accurately than those now considered. As such, it would be wise to use these factors while further research is conducted. There are potential benefits in their use based on existing knowledge and little downside, since the currently used factors have not been tested either. Strength of the claim for relief from deportation and representation are two such factors that are currently ignored but will almost certainly serve a predictive function.

Neither DHS nor the immigration courts currently consider likelihood of success on the merits as a matter of course during the custody determination process. ${ }^{280} \mathrm{~A}$ few BIA cases suggest that the possibility for relief might be considered, but the leading case setting forth the relevant factors does not mention likelihood of success. ${ }^{281}$ The Immigration Judge Benchbook guidance on custody redetermination hearings also omits consideration of the possibility that the migrant will win the right

and interpretations would be necessary to effectuate this review. See supra notes 45-46, 126 and accompanying text.

280. See Rodriguez III, 804 F.3d 1060, 1089-90 (9th Cir. 2015) (noting that custody redetermination hearings do not require evaluation of likelihood of deportation and denying petition to include such evaluation in hearings ordered after prolonged mandatory detention), cert. granted sub nom. Jennings v. Rodriguez, 136 S. Ct. 2489 (2016); Noferi \& Koulish, supra note 13, at 69 (noting that eligibility for relief and likelihood of deportation are not factors considered by DHS, through its risk classification assessment tool, in making initial custody determinations).

281. Guerra, 24 I. \& N. Dec. 37, 40 (B.I.A. 2006), 2006 WL 3337627, at*3. 
to remain in the United States in determining custody. ${ }^{282}$ However, common sense suggests that migrants will appear at hearings and remain law abiding if this behavior will result in a grant of permission to remain in the United States. They are much less likely to comply with immigration court deportation proceedings, and perhaps with the law more generally, if they will almost certainly be deported at the end of their immigration case. ${ }^{283}$ This factor thus merits use even as additional research is conducted.

To be sure, there are some complications in considering the possibility of relief from deportation in determining custody, which will require particular scrutiny during a period of simultaneous implementation and further study. The decision makers on detention, particularly within DHS at the initial custody determination stage, are not in a good position to evaluate the merits of a claim to remain in the United States. They lack sufficient information about the claim and will not be able to unravel the extremely complicated legal issues that are often involved. It is likely that viable claims might not be identified at the initial custody determination stage, potentially leading to continued detention for migrants who will eventually win the right to remain in the United States. Also, the perception of the migrant regarding the possibility of a win may be more important in determining flight risk than objective likelihood of success. It would be hard to measure this subjective belief, and it might change over time. For migrants represented by legal counsel, the problems might not be as severe, since an attorney could help provide information regarding the claim early in the proceedings and could help set reasonable expectations regarding outcomes. This possibility leads to the next consideration.

Currently, representation does not factor into the custody determination process. ${ }^{284}$ However, the existing limited research suggests that represented migrants comply at higher levels with their obligations during pending deportation proceedings. ${ }^{285}$ The involvement of an attorney is thus likely to be predictive of higher appearance rates and overall compliance with the proceedings. Ensuring representation would also make it more possible to evaluate the nature and extent of any other risk indicators, thereby improving the risk assessment process in a way that will likely allow for release of migrants who might have otherwise faced detention. Representation should be treated as an element that requires further research, with consideration in the custody determination process in the meantime.

As with the likelihood-of-success factor, there are problems in considering access to counsel. Legal services available to migrants in deportation proceedings are limited, and it is particularly difficult to obtain counsel while detained. So, consideration of this factor might result in determinations that wealthier or more connected individuals, who can access counsel, present lower risks when they actually do not. However, recognition of representation as a crucial factor in lowering risk may well lead

282. IJ BOND BENCHBOOK, supra note 8.

283. See Das, supra note 9, at 154-55 (suggesting that eligibility for relief should be taken into account for the custody determination process because of this factor's likely impact on flight risk).

284. E.g., Guerra, 24 I. \& N. Dec. at 40, 2006 WL 3337627, at *3; IJ BOND BENCHBOOK, supra note 8 .

285. See supra note 226 and accompanying text. 
to solutions that improve access to counsel in order to address risk rather than using detention for that purpose.

\section{Release and Risk Management}

With identification of the factors that are most predictive of risk, better custody decisions can be made. The factors can be used to develop tools that establish risk levels and identify specific concerns. Migrants not presenting significant risks could be immediately released. Where the relevant factors suggest that release alone would involve meaningful risk, research can help establish the best mechanisms to address specific concerns. These mechanisms can be tailored to effectuate release and then minimize any identified risk factors, except in those rare circumstances where detention is the only possible means to address an identified risk.

Research will help to determine what types of conditions or programs will be effective at achieving compliance after release given specific levels of risk and types of risk factors appearing in a case. However, several promising possibilities for ameliorating risk are not currently considered at all and should be incorporated into the custody determination process immediately while ongoing evaluation takes place.

Measures that would connect unrepresented migrants to counsel are likely to be very effective at addressing risk of flight or danger. In cases involving unrepresented migrants with other identified risk factors, it may be possible to secure compliance with the proceedings by offering representation rather than by detaining. There is no doubt that it would be costly for the government to guarantee access to counsel for individuals in immigration court deportation proceedings who otherwise would not have representation. ${ }^{286}$ However, there are multiple ways to develop a system for ensuring access to counsel in appropriate cases, with varying costs, including: (1) a government-funded, appointed-counsel system, (2) government-funded fellowships and other incentives to expand the immigration bar able to take such cases combined with placement structures for ensuring that identified migrants could be matched with such counsel, (3) governmental financial support to nonprofit and communitybased organizations in conjunction with programs for matching migrants with services in appropriate cases, or (4) government-funded referral services that would place migrants with pro bono programs and attorneys. There are models for some of these possibilities. For example, there are policies and procedures in place to facilitate, if not guarantee, representation of unaccompanied minors. ${ }^{287}$ In any case, the cost should be considered in light of the possibility of achieving compliance with immigration proceedings without detention. If the goal is genuinely to ensure

286. See John D. Montgomery, Cost of Counsel in ImMigration: ECONOMiC ANALysis of Proposal Providing Public Counsel to Indigent Persons Subject To Immigration REMOVAL PROCEEDINGS 3 (2014), http://www.nera.com/content/dam/nera/publications/archive2 /NERA_Immigration_Report_5.28.2014.pdf [https://perma.cc/4HRK-R9GW] (setting forth cost but suggesting that there would be a net savings due to decreased detention time).

287. See 8 U.S.C.A. § 1232(c)(5) (Supp. 2016); 8 U.S.C. § 1362 (2012); Announcement of the Award of Two Single-Source Program Expansion Supplement Grants To Support Legal Services to Refugees Under the Unaccompanied Alien Children's Program, 79 Fed. Reg. 62,159 (Oct. 16, 2014) (announcing award of grants for fellowships that would offer legal services to unaccompanied children). 
appearance at hearings and prevent danger to the community, it will almost certainly be more cost effective to do so through provision of counsel rather than detention in those cases where this trade-off can be made.

Systems for providing hearing reminders and other crucial case-processing information will also likely have a significant positive impact on appearance rates, making it possible to release migrants who will present little-to-no flight risk if they receive this assistance. In the criminal pretrial justice context, numerous studies have shown that hearing reminders are highly effective at improving appearance rates. ${ }^{288}$ In the immigration context, it is often difficult for migrants in deportation proceedings to obtain basic information regarding hearing dates and case processing, and no effort is made to provide better information to encourage appearances without resorting to detention. ${ }^{289}$ To the contrary, elaborate provisions exist to ensure that proceedings can go forward without the appearance of the migrant, through entry of an in absentia order, so long as minimal procedural formalities of notice are met. ${ }^{290}$ These provisions may permit efficient processing of cases, but they do little to ensure that notice is actually received by migrants who may wish to appear for their hearings but lack adequate information. Again, there would be some cost in providing hearing reminders and other information, but this cost would be a minimal burden in comparison with the potential for achieving liberty for greater numbers of migrants while still ensuring low risk of flight. ${ }^{291}$

Other programs might be developed and tested to address specific risk factors that may arise for migrants who might otherwise be likely to comply with their obligations during pending deportation proceedings. For example, community-based housing and case-support programs would almost certainly show themselves to be very effective in addressing risks presented by migrants who do not have family ties or a stable residence and employment in the United States. In the United States and other countries as well, such programs have been successfully used to address flight risk without resorting to detention. ${ }^{292}$

288. VANNOSTRAND ET AL., supra note 212, at 15-20.

289. See, e.g., John Fritze, Immigration Court Speeds Review of Cases Involving Children, BALT. Sun (Aug. 20, 2014, 9:10 PM), http://www.baltimoresun.com/news/maryland/bs-md -immigration-rocket-docket-20140820-story.html [https://perma.cc/SM7J-ZZBS].

290. See, e.g., 8 U.S.C. $§ 1229$ (a) (2012); M-D-, 23 I. \& N. Dec. 540, 545-46 (B.I.A. 2002), 2002 WL 31862204, at *5-7; G-Y-R-, 23 I. \& N. Dec. 181, 186-88 (B.I.A. 2001), 2001 WL 1515819 , at $* 4-7$.

291. The additional reminders would have the goal of securing appearance. Where unsuccessful because of a failure to provide the reminder or because of a migrant's decision not to attend despite having full information, the possibility for an in absentia order would still exist and could provide additional incentives for appearance.

292. See, e.g., Alice Edwards, United Nations High Comm'r for Refugees, BaCK to BAsics: The Right to Liberty AND SeCurity of Person ANd ‘Alternatives to Detention' of Refugees, Asylum-Seekers, Stateless Persons and Other Migrants 60-66 (2011) (providing models of community-based support systems shown to be effective in other countries); Unlocking Human Dignity, supra note 7, at 170 (describing pilot program for community-based case management and integration services for released migrants developed by the U.S. Conference of Catholic Bishops and Catholic Charities); Public Advocate on the Road: Texas Community Engagement, PuB. Advoc. Vorce, Oct. 2012, at 3, https://www.ice.gov /doclib/about/offices/ero/pdf/public-advocate-voice-issue2_10-2012.pdf [https://perma.cc/5J58-TJ3D] 
The research described above will allow for further refinement of risk analysis and for calibration of responses. The findings will need to be converted into concrete standards and tools to guide individual decision makers to ensure their impact on the process. There is great potential, though, for replacing arbitrary detention and bond setting with rational custody determinations that prioritize liberty.

\section{CONCLUSION}

Mass incarceration is in the headlines as a problem facing our nation. ${ }^{293}$ Immigration detention should not be left behind in the discussion of what is to be done. A particularly close look should be taken at the incarceration of migrants in pending immigration court deportation proceedings who are not required by any law or logic to be detained. No problems will be solved by insisting on the continued detention of these migrants who may eventually obtain the right to remain in this country and who will be joining our communities. To the contrary, by restoring the place of liberty and limiting pretrial detention of such migrants, the United States can begin to chip away at the vast and costly problem presented by the imprisonment of large segments of the population. This change can be achieved through reform of the immigration custody determination process to ensure that it fulfills the promise of effectuating freedom, rather than detention, as the norm.

(describing program for release of asylum seekers from detention to a community-based refugee shelter in Austin, Texas). But cf. Unlocking Human Dignity, supra note 7, at 188 (noting that community-based support and case management programs have not traditionally received significant government funding, particularly in comparison with the more libertydepriving electronic monitoring and other supervision programs).

293. President Obama stated that " $[\mathrm{m}]$ ass incarceration makes our country worse off, and we need to do something about it." Remarks at the NAACP Annual Convention in Philadelphia, Pennsylvania, 2015 DAILY COMP. Pres. Doc. 4 (July 14, 2015); see also Pinto, supra note 14 (highlighting pretrial criminal detention as an important component of problematic mass incarceration). 